\title{
\#USGS
}

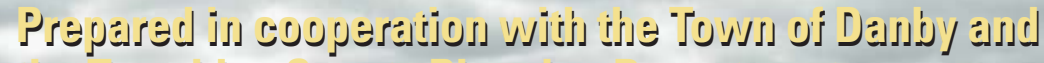

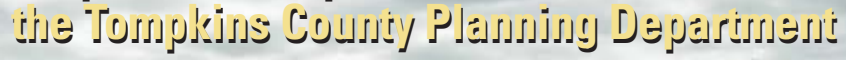

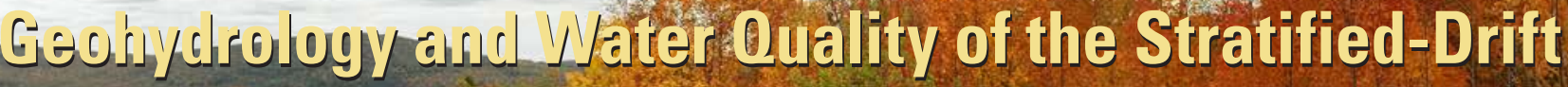
Aquifers in Upper Buttermilk Greek and Danby Creek Valleys, Town of Danby, Tompkins County, New York

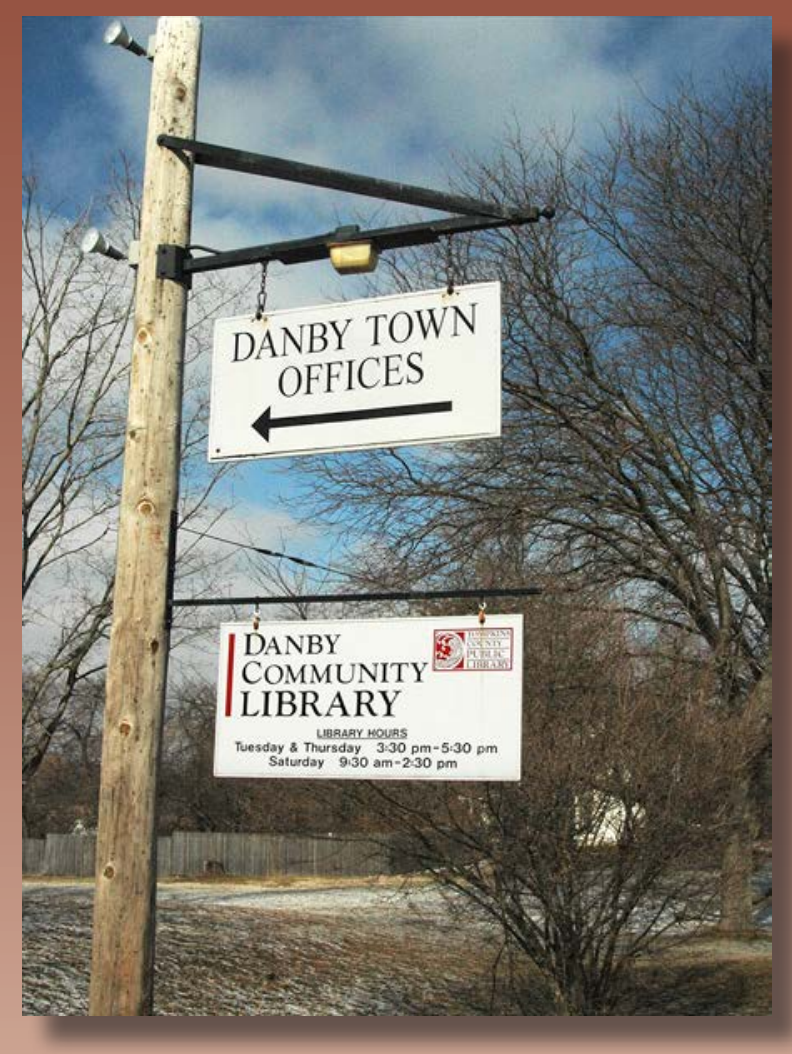

Scientific Investigations Report 2015-5138

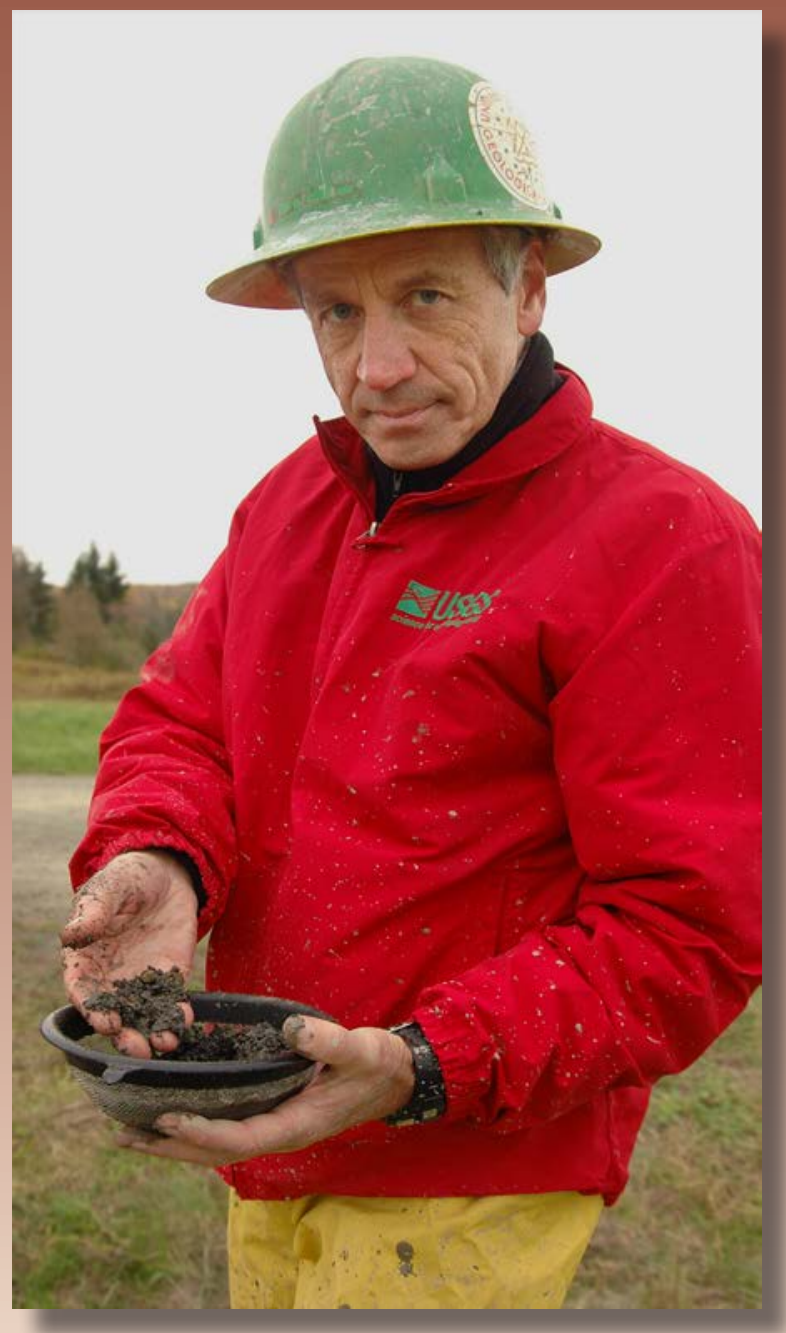

U.S. Department of the Interior U.S. Geological Survey 


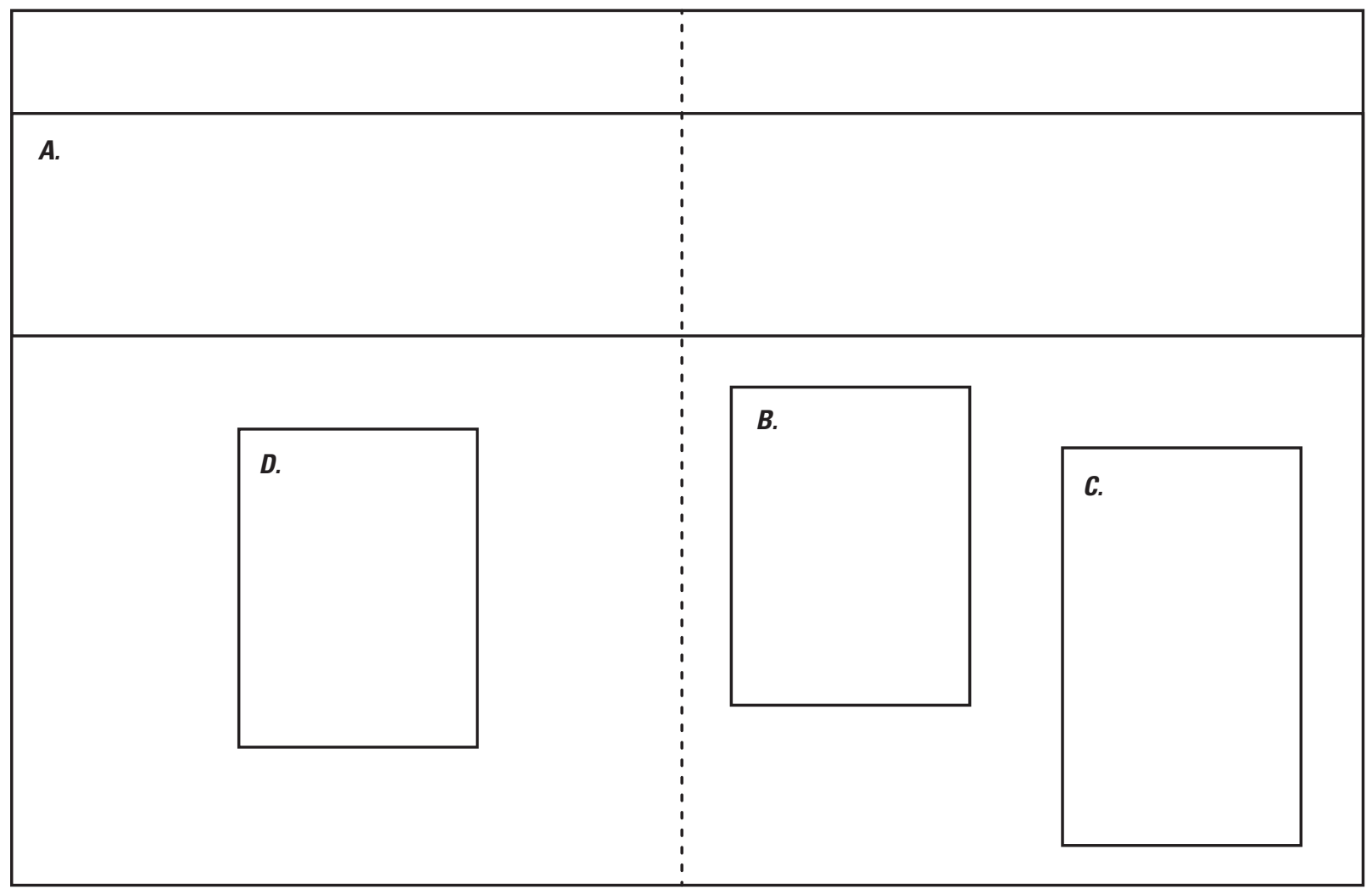

Cover. A, Panorama of the valley from a location near Comfort Road, Danby, N.Y., looking southwest. $B$, Signage for the town offices and public library of the Town of Danby. C, U.S. Geological Survey (USGS) hydrologist holding soil sample from test well TM2806 (Whitehawk Lane, Danby). D, The Danby town hall. All photographs copyright Ted Crane (http://tedcrane.com/), used with permission. 


\section{Geohydrology and Water Quality of the Stratified-Drift Aquifers in Upper Buttermilk Creek and Danby Creek Valleys, Town of Danby, Tompkins County, New York}

By Todd S. Miller

Prepared in cooperation with the Town of Danby and the Tompkins County Planning Department

Scientific Investigations Report 2015-5138 


\title{
U.S. Department of the Interior SALLY JEWELL, Secretary
}

\section{U.S. Geological Survey \\ Suzette M. Kimball, Acting Director}

\author{
U.S. Geological Survey, Reston, Virginia: 2015
}

For more information on the USGS - the Federal source for science about the Earth, its natural and living resources, natural hazards, and the environment—visit http://www.usgs.gov or call 1-888-ASK-USGS.

For an overview of USGS information products, including maps, imagery, and publications, visit http://www.usgs.gov/pubprod/.

Any use of trade, firm, or product names is for descriptive purposes only and does not imply endorsement by the U.S. Government.

Although this information product, for the most part, is in the public domain, it also may contain copyrighted materials as noted in the text. Permission to reproduce copyrighted items must be secured from the copyright owner.

Suggested citation:

Miller, T.S., 2015, Geohydrology and water quality of the stratified-drift aquifers in upper Buttermilk Creek and Danby Creek valleys, Town of Danby, Tompkins County, New York: U.S. Geological Survey Scientific Investigations Report 2015-5138, 66 p., http://dx.doi.org/10.3133/sir20155138.

ISSN 2328-0328 (online) 


\section{Contents}

Abstract

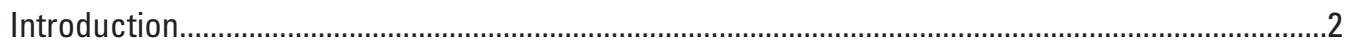

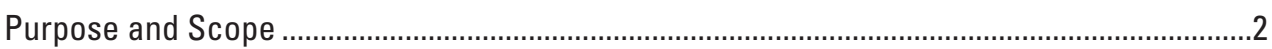

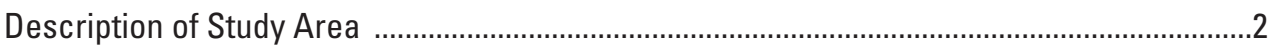

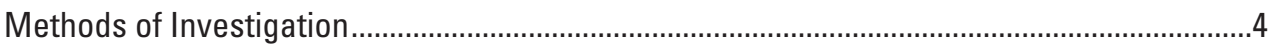

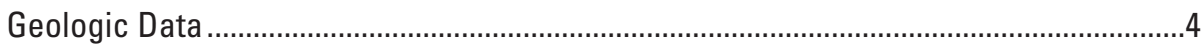

Well Inventory, Test Drilling, Water-Level Measurements, and Levels .............................4

Streamflow Measurements, Water Sampling, and Water Analysis ................................7

Seismic-Refraction Surveys ...........................................................................................

Geology

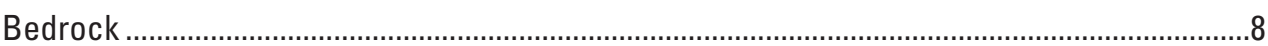

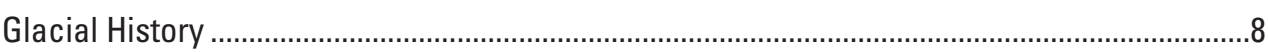

High-Altitude Valleys Little Affected by Ice Scour .............................................................

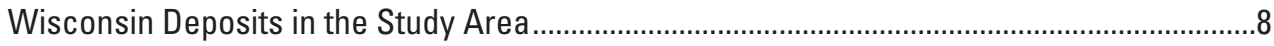

Geohydrology of the Stratified-Drift Aquifer System .............................................................11

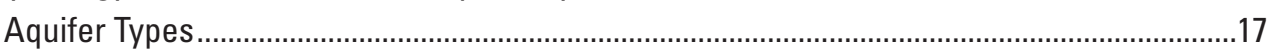

Upper Buttermilk Creek Valley ..................................................................................

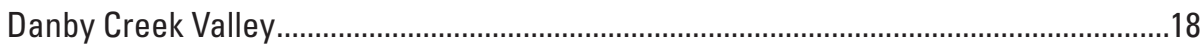

Michigan Creek Valley ...............................................................................................

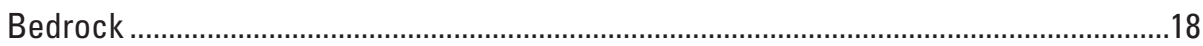

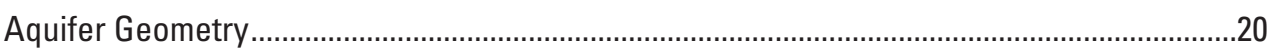

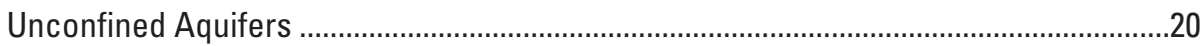

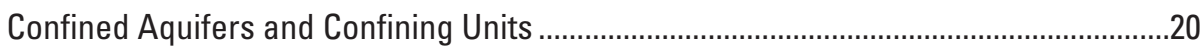

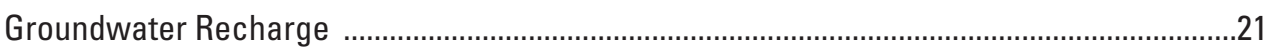

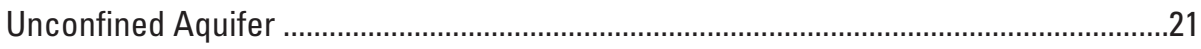

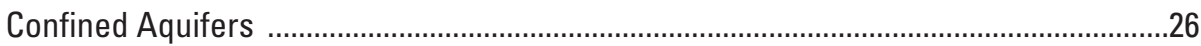

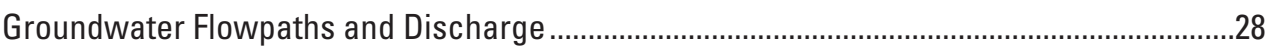

Groundwater Withdrawals..............................................................................................28

Potential for Large-Capacity Municipal or Commercial Wells..................................................28

Unconfined Aquifer in Lower Danby Creek Valley .........................................................28

Confined Aquifers in Upper Buttermilk Creek Valley ........................................................30

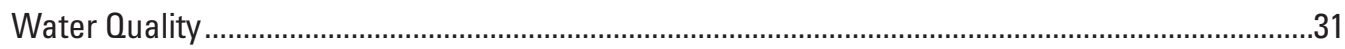

Surface Water

Physiochemical Properties, Inorganic Major lons, Nutrients, and Trace Elements ......31

Inorganic Major lons...............................................................................................

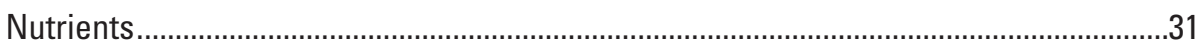

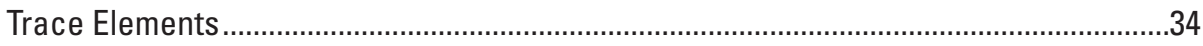

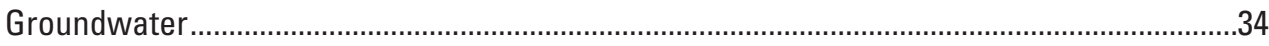

Physical and Physiochemical Properties .....................................................................

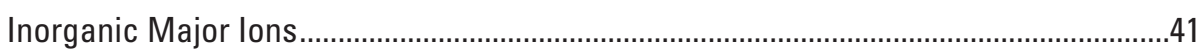

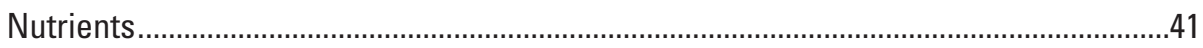

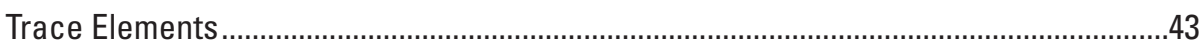




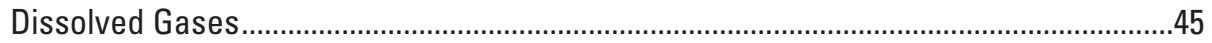

Comparison to Other Stratified-Drift Aquifers in Tompkins County.........................................45

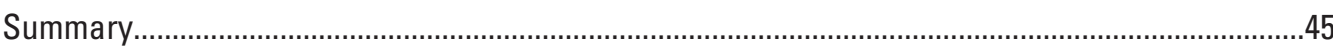

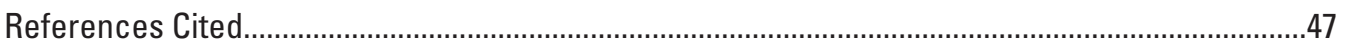

Appendix 1. Records of Wells, Town of Danby, Tompkins County, New York ............................51

Appendix 2. Well Logs and Construction Details of U.S. Geological Survey Test Wells ...............61

\section{Figures}

1. Map showing location of 17 stratified-drift (unconsolidated) aquifers in Tompkins County, New York

2. Map showing physiographic features of New York and location of the upper Buttermilk Creek and Danby Creek valleys study area in Tompkins County, New York ...4

3. Map showing location of the stratified-drift aquifers in the Town of Danby, the Susquehanna River and St. Lawrence River drainage divide, and the Buttermilk Creek and Danby Creek subbasins, Tompkins County, New York .

4. Map showing shaded relief and boundary of stratified-drift aquifer study area in the upper Buttermilk Creek and Danby Creek Valleys, Tompkins County, New York .......6

5. Map showing bedrock and structural geology of the Town of Danby, Tompkins County, New York

6. Map showing surficial geology of upper Buttermilk Creek, Danby Creek, and Michigan Creek Basins, Town of Danby, Tompkins County, New York.

7. Geohydrologic section $A-A^{\prime}$ across the northern part of upper Buttermilk Creek valley, Town of Danby, Tompkins County, New York

8. Geohydrologic section B-B' across the headwaters of upper Buttermilk Creek and Danby Creek valleys near the hamlet of Danby, Town of Danby, Tompkins County, New York

9. Geohydrologic section $\mathrm{C}-\mathrm{C}^{\prime}$ across Danby Creek valley, along Steam Mill Road, Town of Danby, Tompkins County, New York.

10. Geohydrologic section D-D' across Danby Creek valley, along Durfee Hill Road, Town of Danby, Tompkins County, New York.

11. Map showing location of wells in the Town of Danby, Tompkins County, New York. ....16

12. Map showing the types of stratified-drift aquifers in the upper Buttermilk Creek, Danby Creek, and Michigan Creek valleys in the Town of Danby, Tompkins County, New York.

13. Graph showing altitude of groundwater levels in test wells TM2467, (near Town of Danby Highway Department) from June 1, 2008, to June 26, 2012, TM2588 (near the Hamlet of Danby) from December 17, 2008, to March 30, 2011, and TM2591, (Steam Mill Road) from February 11, 2009, to June 26, 2012, Town of Danby, New York.

14. Schematic geohydrologic sections showing sources of recharge to aquifers in the A, northern part of the study area (upper Buttermilk Creek valley); B, central part of the study area (upper Buttermilk Creek valley); and C, southern part of the study area (Danby Creek valley), Tompkins County, New York

15. Map showing channeled and unchanneled upland drainage basins that provide recharge to the unconfined aquifers in the upper Buttermilk Creek, Danby Creek, and Michigan Creek valleys in the Town of Danby, Tompkins County, New York. 
16. Hydrograph showing altitude of groundwater levels in wells TM1008 and TM1009 finished in aquifers under high degree of confinement, lower Sixmile Creek valley, Town of Caroline, Tompkins County, New York.

17. Map showing water table in unconfined aquifers and the potentiometric surface in the confined aquifer in the upper Buttermilk Creek, Danby Creek, and Michigan Creek valleys in the Town of Danby, Tompkins County, New York...

18. Map showing the location of groundwater and surface-water sampling sites in upper Buttermilk Creek and Danby Creek valleys, Town of Danby, Tompkins County, New York.

19. Graph showing the distribution of arsenic concentrations from groundwater samples in stratified-drift aquifers in Tompkins County from 2000-10 in Tompkins County, New York.

20. Piper diagram showing variability in major ion composition of groundwater in upper Buttermilk Creek and Danby Creek valleys, Virgil Creek and Dryden Lake valleys, Lower Sixmile Creek and Willseyville Creek trough, and upper Sixmile Creek and West Branch Owego Creek valleys, Tompkins County, New York

2-1. Well log and well construction details of U.S. Geological Survey test well TM2588 near the Hamlet of Danby, Town of Danby, Tompkins County, New York.

2-2. Well log and well construction details of U.S. Geological Survey test well TM2467 at the Danby Highway Department near Hornbrook Road, Town of Danby, Tompkins County, New York

2-3. Well logs and well construction details of U.S. Geological Survey test wells TM2590 and TM1035, Durfee Hill Road, Town of Danby, Tompkins County, New York...64

2-4. Well log and well construction details of U.S. Geological Survey test wells TM2589 and TM2591, Steam Mill Road, Town of Danby, Tompkins County, New York ..

2-5. Well log and well construction details of U.S. Geological Survey test well TM2806, Whitehawk Lane, Town of Danby, Tompkins County, New York

\section{Tables}

1. Range, mean, and median of well depths and reported well yields in the Town of Danby, New York.

2. Estimated average annual recharge to the contiguous unconfined aquifer in Danby Creek valley, Town of Danby, New York.

3. Estimated groundwater withdrawals by users that reside over the upper Buttermilk Creek and Danby Creek valleys aquifer-system study area, 2012..

4. Physiochemical properties of, and concentrations of inorganic major ions and nutrients in surface-water samples from Buttermilk Creek, selected tributaries to Buttermilk Creek, and Danby Creek, Town of Danby, New York, July 31, 2008

5. Concentrations of trace metals in surface-water samples from Buttermilk Creek, selected tributaries to Buttermilk Creek, and Danby Creek, Town of Danby, New York, July 31, 2008.

6. Summary statistics for physiochemical properties, concentrations of inorganic major ions, and selected nutrients in surface-water and groundwater samples collected in the upper Buttermilk Creek and Danby Creek valleys, Town of Danby, New York, 2007-10

7. Summary statistics for concentrations of trace elements in surface-water and groundwater samples collected in the upper Buttermilk Creek and Danby Creek valleys, Town of Danby, New York, 2007-10. 
8. Physical and physiochemical properties of; and concentrations of inorganic major ions and nutrients in groundwater samples from stratified-drift and bedrock aquifers in the Town of Danby, New York, 2007-08.

9. Concentrations of trace elements in groundwater samples from stratified-drift and bedrock aquifers in the upper Buttermilk Creek and Danby Creek valleys, Town of Danby, New York, 2007-08.

10. Physical and physiochemical properties of; and concentrations of inorganic major ions, trace elements, nutrients, selected radiochemicals, and dissolved gases in groundwater samples from bedrock and stratified-drift aquifers in the Town of Danby, New York, 2010

Appendix 1. Records of wells, Town of Danby, Tompkins County, New York 


\section{Conversion Factors}

\begin{tabular}{|c|c|c|}
\hline Multiply & By & To obtain \\
\hline \multicolumn{3}{|c|}{ Length } \\
\hline foot (ft) & 0.3048 & meter $(\mathrm{m})$ \\
\hline mile (mi) & 1.609 & kilometer $(\mathrm{km})$ \\
\hline \multicolumn{3}{|c|}{ Area } \\
\hline square foot $\left(\mathrm{ft}^{2}\right)$ & 0.09290 & square meter $\left(\mathrm{m}^{2}\right)$ \\
\hline square foot $\left(\mathrm{ft}^{2}\right)$ & 0.000000036 & square mile $\left(\mathrm{mi}^{2}\right)$ \\
\hline square inch $\left(\mathrm{in}^{2}\right)$ & 6.452 & square centimeter $\left(\mathrm{cm}^{2}\right)$ \\
\hline square mile $\left(\mathrm{mi}^{2}\right)$ & 2.590 & square kilometer $\left(\mathrm{km}^{2}\right)$ \\
\hline square mile $\left(\mathrm{mi}^{2}\right)$ & $27,878,400$ & square feet $\left(\mathrm{ft}^{2}\right)$ \\
\hline \multicolumn{3}{|c|}{ Volume } \\
\hline gallon (gal) & 0.003785 & cubic meter $\left(\mathrm{m}^{3}\right)$ \\
\hline gallon (gal) & 3.785 & liter $(\mathrm{L})$ \\
\hline million gallons (Mgal) & 3,785 & cubic meter $\left(\mathrm{m}^{3}\right)$ \\
\hline cubic foot $\left(\mathrm{ft}^{3}\right)$ & 0.02832 & cubic meter $\left(\mathrm{m}^{3}\right)$ \\
\hline \multicolumn{3}{|c|}{ Flow rate } \\
\hline foot per year (ft/yr) & 0.3048 & meter per year $(\mathrm{m} / \mathrm{yr})$ \\
\hline cubic foot per second $\left(\mathrm{ft}^{3} / \mathrm{s}\right)$ & 0.02832 & cubic meter per second $\left(\mathrm{m}^{3} / \mathrm{s}\right)$ \\
\hline cubic foot per second $\left(\mathrm{ft}^{3} / \mathrm{s}\right)$ & 86,400 & cubic foot per day $\left(\mathrm{ft}^{3} / \mathrm{d}\right)$ \\
\hline cubic foot per second $\left(\mathrm{ft}^{3} / \mathrm{s}\right)$ & $31,536,000$ & cubic foot per day $\left(\mathrm{ft}^{3} / \mathrm{yr}\right)$ \\
\hline cubic foot per second $\left(\mathrm{ft}^{3} / \mathrm{s}\right)$ & 646,317 & million gallons per day $(\mathrm{Mgal} / \mathrm{d})$ \\
\hline cubic foot per second $\left(\mathrm{ft}^{3} / \mathrm{s}\right)$ & $23,592,505$ & million gallons per year (Mgal/yr) \\
\hline $\begin{array}{l}\text { cubic foot per second per square mile } \\
{\left[\left(\mathrm{ft}^{3} / \mathrm{s}\right) / \mathrm{mi}^{2}\right]}\end{array}$ & 0.01093 & $\begin{array}{l}\text { cubic meter per second per square } \\
\text { kilometer }\left[\left(\mathrm{m}^{3} / \mathrm{s}\right) / \mathrm{km}^{2}\right]\end{array}$ \\
\hline cubic foot per day $\left(\mathrm{ft}^{3} / \mathrm{d}\right)$ & 0.02832 & cubic meter per day $\left(\mathrm{m}^{3} / \mathrm{d}\right)$ \\
\hline cubic foot per year $\left(\mathrm{ft}^{3} / \mathrm{yr}\right)$ & 0.00000748 & million gallons per year (Mgal/yr) \\
\hline gallon per minute (gal/min) & 0.06309 & liter per second $(\mathrm{L} / \mathrm{s})$ \\
\hline gallon per day (gal/d) & 0.003785 & cubic meter per day $\left(\mathrm{m}^{3} / \mathrm{d}\right)$ \\
\hline million gallons per day (Mgal/d) & 0.04381 & cubic meter per second $\left(\mathrm{m}^{3} / \mathrm{s}\right)$ \\
\hline million gallons per day (Mgal/yr) & 1.547 & cubic foot per second $\left(\mathrm{ft}^{3} / \mathrm{s}\right)$ \\
\hline $\begin{array}{l}\text { million gallons per day per square mile } \\
\qquad\left[(\mathrm{Mgal} / \mathrm{d}) / \mathrm{mi}^{2}\right]\end{array}$ & 1,461 & $\begin{array}{l}\text { cubic meter per day per square } \\
\text { kilometer }\left[\left(\mathrm{m}^{3} / \mathrm{d}\right) / \mathrm{km}^{2}\right]\end{array}$ \\
\hline inch per year (in/yr) & 25.4 & millimeter per year $(\mathrm{mm} / \mathrm{yr})$ \\
\hline \multicolumn{3}{|c|}{ Radioactivity } \\
\hline picocurie per liter $(\mathrm{pCi} / \mathrm{L})$ & 0.037 & becquerel per liter $(\mathrm{Bq} / \mathrm{L})$ \\
\hline \multicolumn{3}{|c|}{ Hydraulic conductivity } \\
\hline foot per day $(\mathrm{ft} / \mathrm{d})$ & 0.3048 & meter per day $(\mathrm{m} / \mathrm{d})$ \\
\hline \multicolumn{3}{|c|}{ Hydraulic gradient } \\
\hline foot per mile $(\mathrm{ft} / \mathrm{mi})$ & 0.1894 & meter per kilometer $(\mathrm{m} / \mathrm{km})$ \\
\hline
\end{tabular}

Temperature in degrees Celsius $\left({ }^{\circ} \mathrm{C}\right)$ may be converted to degrees Fahrenheit

$\left({ }^{\circ} \mathrm{F}\right)$ as $^{\circ} \mathrm{F}=\left(1.8 \times{ }^{\circ} \mathrm{C}\right)+32$.

Temperature in degrees Fahrenheit $\left({ }^{\circ} \mathrm{F}\right)$ may be converted to degrees Celsius

$\left({ }^{\circ} \mathrm{C}\right)$ as ${ }^{\circ} \mathrm{C}=\left({ }^{\circ} \mathrm{F}-32\right) / 1.8$. 


\section{Supplemental Information}

Specific conductance is given in microsiemens per centimeter at 25 degrees Celsius ( $\mu \mathrm{S} / \mathrm{cm}$ at $\left.25^{\circ} \mathrm{C}\right)$.

Concentrations of chemical constituents in water are given in either milligrams per liter ( $\mathrm{mg} / \mathrm{L}$ ) or micrograms per liter $(\mu \mathrm{g} / \mathrm{L})$.

\section{Datum}

Vertical coordinate information is referenced to the North American Vertical Datum of 1988 (NAVD 88) where light detection and ranging (lidar) and Digital Elevation Model (DEM) data were used, and to the National Geodetic Vertical Datum of 1929 (NGVD 29) elsewhere.

Horizontal coordinate information is referenced to North American Datum of 1983 (NAD 83).

Altitude, as used in this report, refers to distance above the vertical datum.

\section{Abbreviations}

CFCL

EPA

HA

HVSR

lidar

MCL

NAD 83

NAVD 88

NWOL

NYSDEC

NYSDOH

SDWS

SMCL

USGS
USGS Chlorofluorocarbon Laboratory

U.S. Environmental Protection Agency

EPA Health Advisory

horizontal-to-vertical spectral ratio

light detection and ranging

EPA Maximum Contaminant Level

North American Datum of 1983

North American Vertical Datum of 1988

USGS National Water Quality Laboratory

New York State Department of Environmental Conservation

New York State Department of Health

EPA Secondary Drinking-Water Standards

Secondary Maximum Contaminant Level

U.S. Geological Survey 


\title{
Geohydrology and Water Quality of the Stratified-Drift Aquifers in Upper Buttermilk Creek and Danby Creek Valleys, Town of Danby, Tompkins County, New York
}

\author{
By Todd S. Miller
}

\begin{abstract}
In 2006, the U.S. Geological Survey, in cooperation with the Town of Danby and the Tompkins County Planning Department, began a study of the stratified-drift aquifers in the upper Buttermilk Creek and Danby Creek valleys in the Town of Danby, Tompkins County, New York. In the northern part of the north-draining upper Buttermilk Creek valley, there is only one sand and gravel aquifer, a confined basal unit that overlies bedrock. In the southern part of upper Buttermilk Creek valley, there are as many as four sand and gravel aquifers, two are unconfined and two are confined. In the south-draining Danby Creek valley, there is an unconfined aquifer consisting of outwash and kame sand and gravel (deposited by glacial meltwaters during the late Pleistocene Epoch) and alluvial silt, sand, and gravel (deposited by streams during the Holocene Epoch). In addition, throughout the study area, there are several small local unconfined aquifers where large tributaries deposited alluvial fans in the valley.

The principal sources of recharge to the unconfined aquifers in the study area include direct infiltration of precipitation (rain and snowmelt) at land surface, unchanneled surface runoff from adjacent hillsides that seeps into the aquifer along the edges of the valley, groundwater inflow from adjacent till and bedrock that enters the aquifer along the sides of the valley, and seepage loss from uplandtributary streams where they flow over their alluvial fans in the valley. The percentages of all sources of recharge to the contiguous unconfined aquifer in Danby Creek valley include 16 percent from precipitation that falls directly over the aquifer, 55 percent from unchanneled surface runoff and groundwater inflow from hillsides, and 29 percent from losing tributary streams that cross the aquifer. The total annual recharge to the contiguous unconfined aquifer is 2.56 cubic feet per second (604 million gallons per year).

The principal sources of recharge to the confined aquifers include precipitation that falls directly on the surficial confining unit, which then slowly flows vertically downward
\end{abstract}

through the fine-grained sediments and enters the confined aquifer, and groundwater inflow from till and bedrock that borders the aquifer along adjacent hillsides and at the bottom of the valley. In addition, there is substantial amounts of recharge to the confined aquifers where the confining units are locally absent (forming windows) and where parts of the confining units consist of sediments of low to moderate permeability (forming a semiconfining layer).

In the northern part of the study area (upper Buttermilk Creek valley), groundwater in the stratified-drift aquifers discharges to (1) domestic and commercial wells; (2) Buttermilk Creek in the area near the northern town border, and (3) and a small unnamed stream in a ravine in Buttermilk State Park just north of the town border. In the southern part of the study area (Danby Creek valley), groundwater discharges (1) to domestic, commercial, and farm wells; (2) to Danby Creek; (3) to a large wetland in the central parts of Danby Creek valley; and (4) as losses because of plant uptake and evaporation. About 300 people depend on groundwater from the upper Buttermilk Creek and Danby Creek stratifieddrift aquifer system.

An unconfined surficial aquifer about 8,000 feet (ft) long and as much as $800 \mathrm{ft}$ wide, with a saturated thickness of about $20 \mathrm{ft}$, occupies the lower (southeastern most) 8,000 ft of Danby Creek valley within the Town of Danby. However, because the aquifer is thin, the volume of water stored in the aquifer is small and the potential for induced recharge from Danby Creek during summer periods of low flow is also small, an array of wells would probably be needed to provide sustainable continuous amount of water to large water users such as municipalities and industries. Additional data and a groundwater flow model would be required to estimate sustainable withdrawal from the confined aquifers in upper Buttermilk Creek valley.

Well data from water-well drillers through 2012 indicate that the confined aquifers in upper Buttermilk Creek valley are thin (typically about 10 feet thick) and the reported well-yield data suggest these aquifers may not be capable of supplying sufficient water to meet the needs of municipalities and 
industries. However, additional geohydrologic data leading to calibration of a groundwater flow model would be needed to properly evaluate the long-term (multiple years) potential yield of the confined aquifer system in upper Buttermilk Creek valley and of the unconfined aquifer in Danby Creek valley.

During 2007-10, groundwater samples were collected from 13 wells including 7 wells that are completed in the confined sand and gravel aquifers, 1 well that is completed in the unconfined aquifer, and 5 wells that are completed in the bedrock aquifers. Calcium dominates the cation composition and bicarbonate dominates the anion composition in most groundwater. Water quality in the study area generally meets state and Federal drinking-water standards but concentrations of some constituents exceeded the standards. The standards that were exceeded include sodium ( 3 samples), dissolved solids (1 sample), iron (3 samples), manganese (8 samples), and arsenic (1 sample).

\section{Introduction}

In 2000, the U.S. Geological Survey published a map depicting the extent of stratified-drift (that is, sand and gravel) aquifers in Tompkins County (Miller, 2000), which was a reconnaissance of the area. In 2000-02, the U.S. Geological Survey and the Tompkins County Planning Department used the map to plan studies of the stratified-drift aquifers in more detail. These detailed studies would provide geohydrologic data for town and county planners to develop a strategy to manage and protect their water resources. In developing the plan, a list of a 17 stratified-drift aquifers was compiled and a program was developed to study these aquifers for 20 years. The extent of the aquifers was based mostly on natural hydrologic boundaries, but in some cases, political boundaries were used as well; In order to have manageablesized study areas, the aquifer extents were about 3 to 5 miles (mi) each. During 2006-12, the upper Buttermilk Creek and Danby Creek valleys (fig. 1) were the third aquifer study to be investigated of the county-wide program. The aquifer was investigated by the U.S. Geological Survey, in cooperation with the Tompkins County Planning Department and the Town of Danby.

Evaluation, development, and protection of these aquifers require information on the aquifer framework (the threedimensional extent and distribution of aquifers and confining units), sources of recharge, discharge areas, direction of groundwater flow, and water quality. Samples were collected from wells to characterize the chemical quality of groundwater and to determine whether the water is potable. Groundwater samples were collected from wells that are finished in the confined and unconfined aquifers as well as several wells that are finished in bedrock. A comparison of water quality was made to determine whether there are differences between the sand and gravel aquifers and bedrock aquifers. In addition, stream samples were collected to characterize the chemical quality of surface water under base-flow conditions (when the flow is mostly from groundwater discharging into stream channels) and to determine whether there are similarities in water quality between surface water and groundwater.

\section{Purpose and Scope}

This report describes the geohydrology of the stratifieddrift aquifers in upper Buttermilk Creek and Danby Creek valleys in the Town of Danby, Tompkins County. Specifically, the report contains information that details the study results: (1) the geology of the study area including the geologic framework of the aquifer system; (2) the groundwater-flow system, including information about water levels, groundwater and surface-water interaction, direction of groundwater flow, and recharge and discharge conditions; and (3) the water quality, including information about concentrations of common inorganic ions, nutrients, and trace elements. The report also includes geohydrologic sections; maps and diagrams depicting well locations, geology, groundwater levels, and direction of groundwater flow; and tables of well records and water-quality data.

\section{Description of Study Area}

The study area is in the Appalachian Plateau physiographic province (fig. 2). The plateau is characterized by hills and valleys that resulted from millions of years of dissection by initially south-flowing streams that were captured by advancing northward-flowing streams. Those streams drained into Lake Ontario (fig. 2). The hills and valleys have been subsequently modified by several glaciations.

The stratified-drift aquifer system in the upper Buttermilk Creek and Danby Creek valleys is one of the 17 stratified-drift aquifers in Tompkins County that were mapped by the USGS (Miller, 2000). The stratified-drift aquifer system in the upper Buttermilk Creek and Danby Creek valleys is one of two stratified-drift aquifer systems in the Town of Danby - the other aquifer system is in the Cayuga Inlet valley in the southwest part of the town (figs. 1 and 3). However, the aquifer system in the upper Cayuga Inlet valley is not part of this investigation.

The study area is $7.5 \mathrm{mi}$ long and encompasses 4.7 square miles $\left(\mathrm{mi}^{2}\right)$ in the upper Buttermilk Creek and Danby Creek valleys (fig. 3). Buttermilk Creek flows northward in a valley until it cascades over several waterfalls through Buttermilk Creek gorge before it joins lower Cayuga Inlet trough that is $2.7 \mathrm{mi}$ north of the Town of Danby (fig. 3). Cayuga Inlet then drains into Cayuga Lake at Ithaca (fig. 3). Southeastward flowing Danby Creek is a headwater tributary of the Susquehanna River Basin (fig. 3).

The study area has moderate relief with altitudes ranging from as low as $965 \mathrm{ft}$ above North American Vertical Datum 


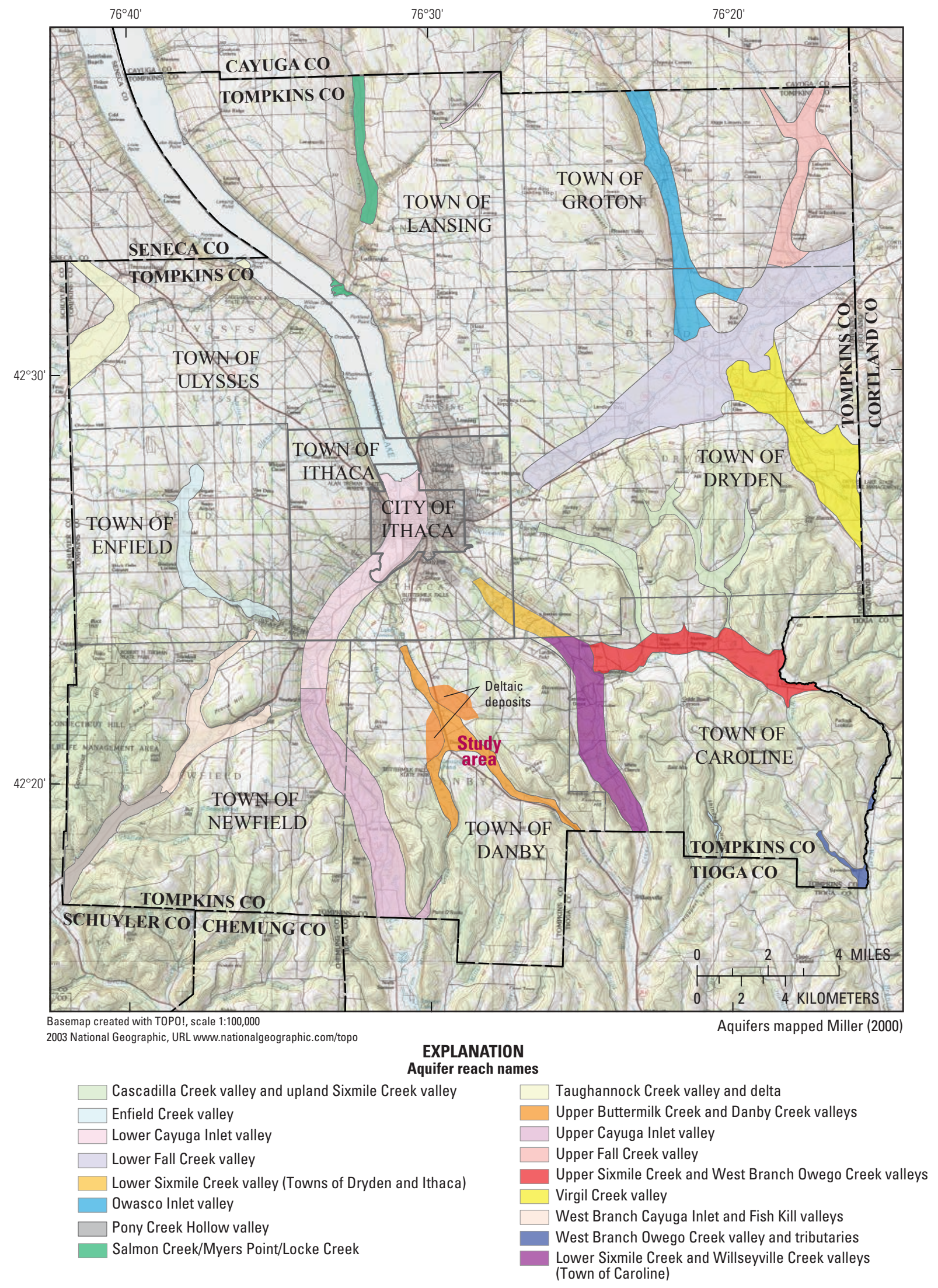

Figure 1. Location of 17 stratified-drift (unconsolidated) aquifers in Tompkins County, New York. 


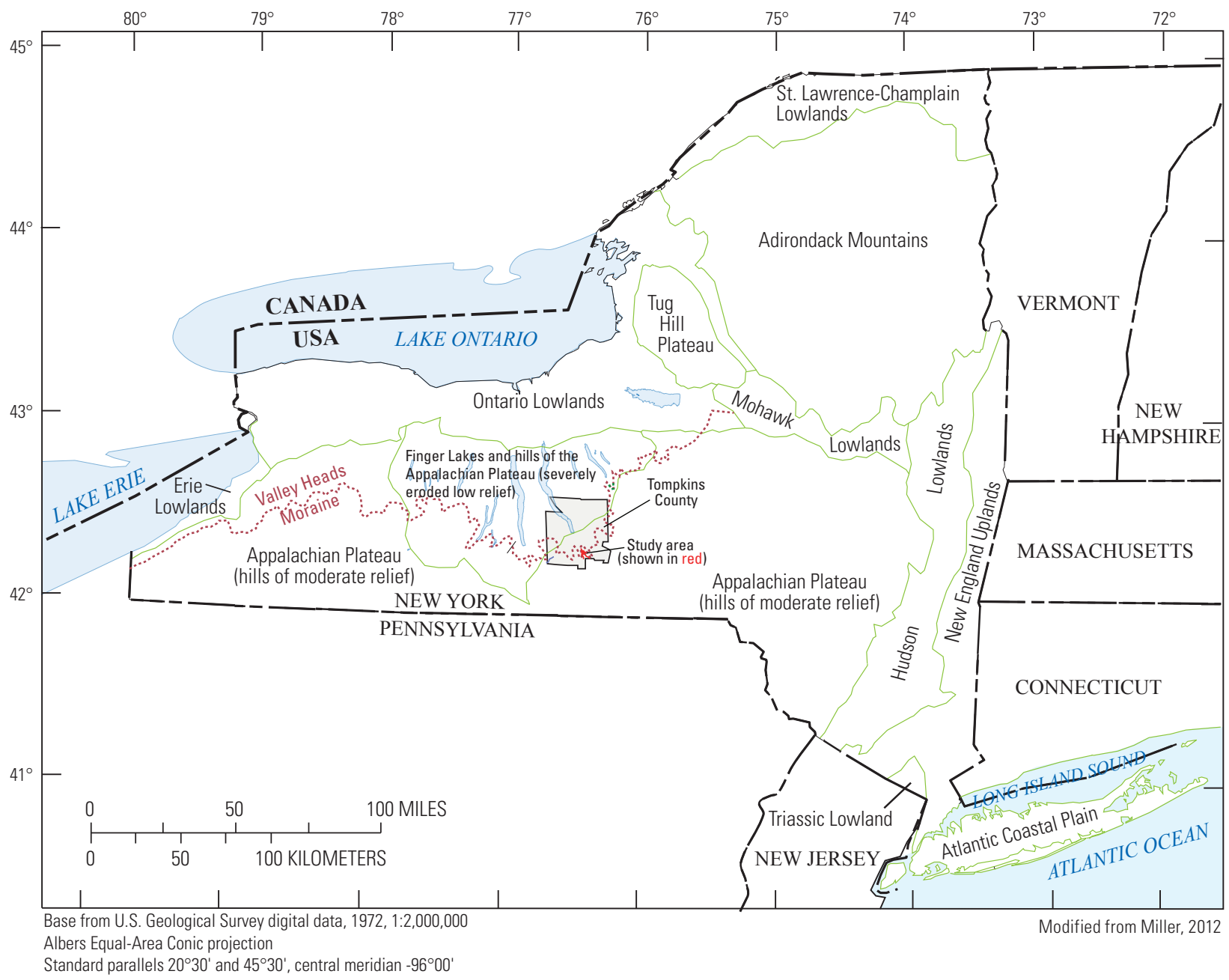

Figure 2. Physiographic features of New York and location of the upper Buttermilk Creek and Danby Creek valleys study area in Tompkins County, New York.

of 1988 (NAVD 88) in the channel where Buttermilk Creek enters the Buttermilk Creek gorge in the north part of the study area to about $1,800 \mathrm{ft}$ on the highest hilltops (fig. 4). Buttermilk Creek and Danby Creek valleys are relatively highaltitude valleys that are 100 to $500 \mathrm{ft}$ higher than the Cayuga Inlet trough to the west and north, and the lower Sixmile Creek and Willseyville Creek trough to the east (figs. 3 and 4).

\section{Methods of Investigation}

Existing data were compiled and new data were collected for this study. Existing data included well records, geologic reports, and soil maps. New data included geologic mapping, test drilling, seismic surveys, groundwater-level measurements, and surface-water and groundwater-quality sampling.

\section{Geologic Data}

This report includes geologic mapping that modifies the geology published by Muller and Cadwell (1986). In addition to interpretation from topographic maps and orthophotographs, soil maps (Neeley, 1961) were used in geologic interpretation.

Geologic data were also collected by seismic-refraction and horizontal-to-vertical spectral ratio (HVSR) seismic surveys to supplement data from test drilling. The seismic surveys were used to determine the thickness of the unconsolidated deposits and depth to bedrock.

\section{Well Inventory, Test Drilling, Water-Level Measurements, and Levels}

Well records (140 records, appendix 1) were collected and compiled for wells in the Town of Danby. Sources of 


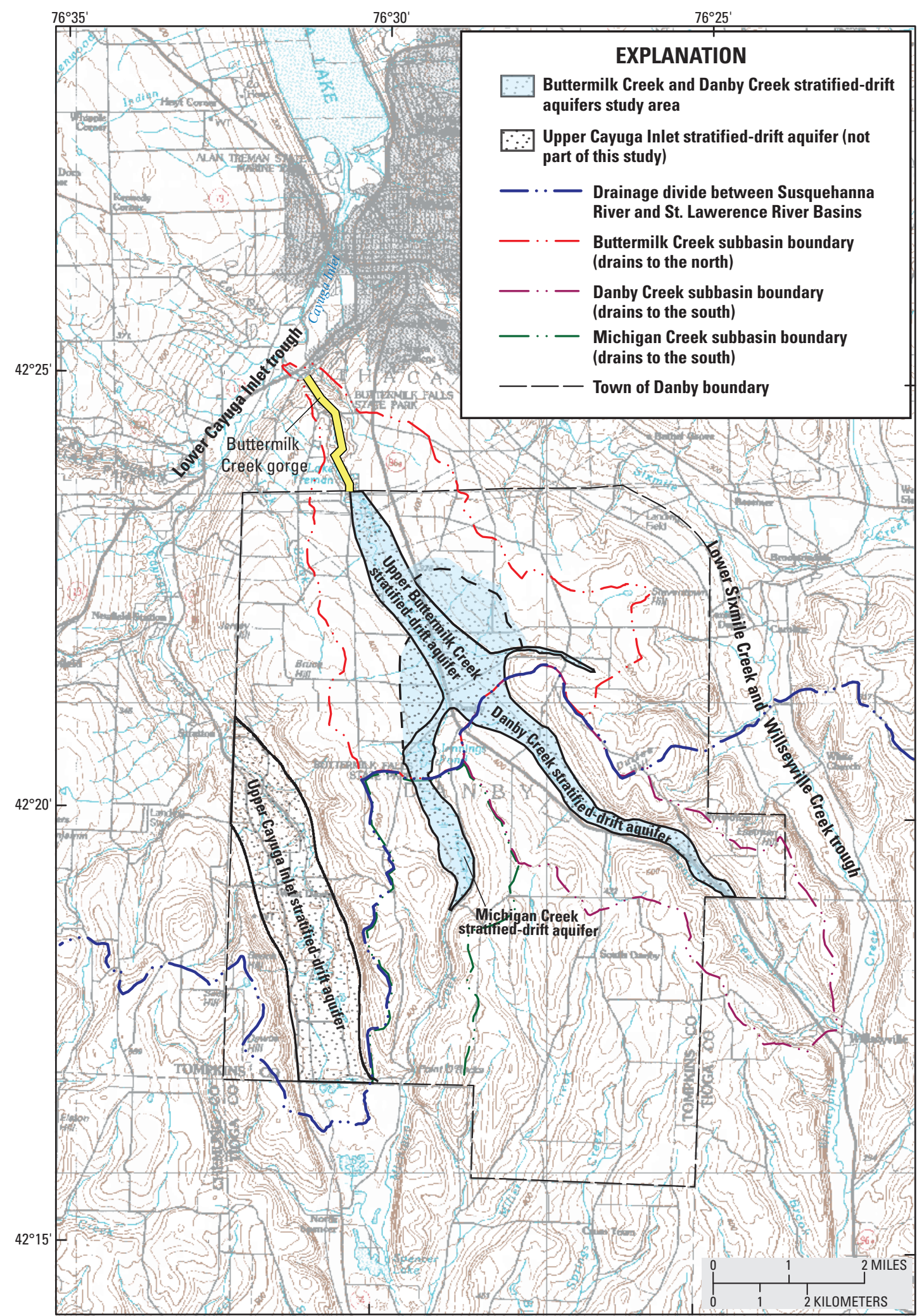

Base from U.S. Geological Survey, Seamless Data Distribution System scale 1:100,000, contour interval 20 feet accessed in 2008 at http://seamless.usgs.gov/

Universal Transverse Mercator projection, zone 18

Figure 3. Location of the stratified-drift aquifers in the Town of Danby, the Susquehanna River and St. Lawrence River drainage divide, and the Buttermilk Creek and Danby Creek subbasins, Tompkins County, New York. 


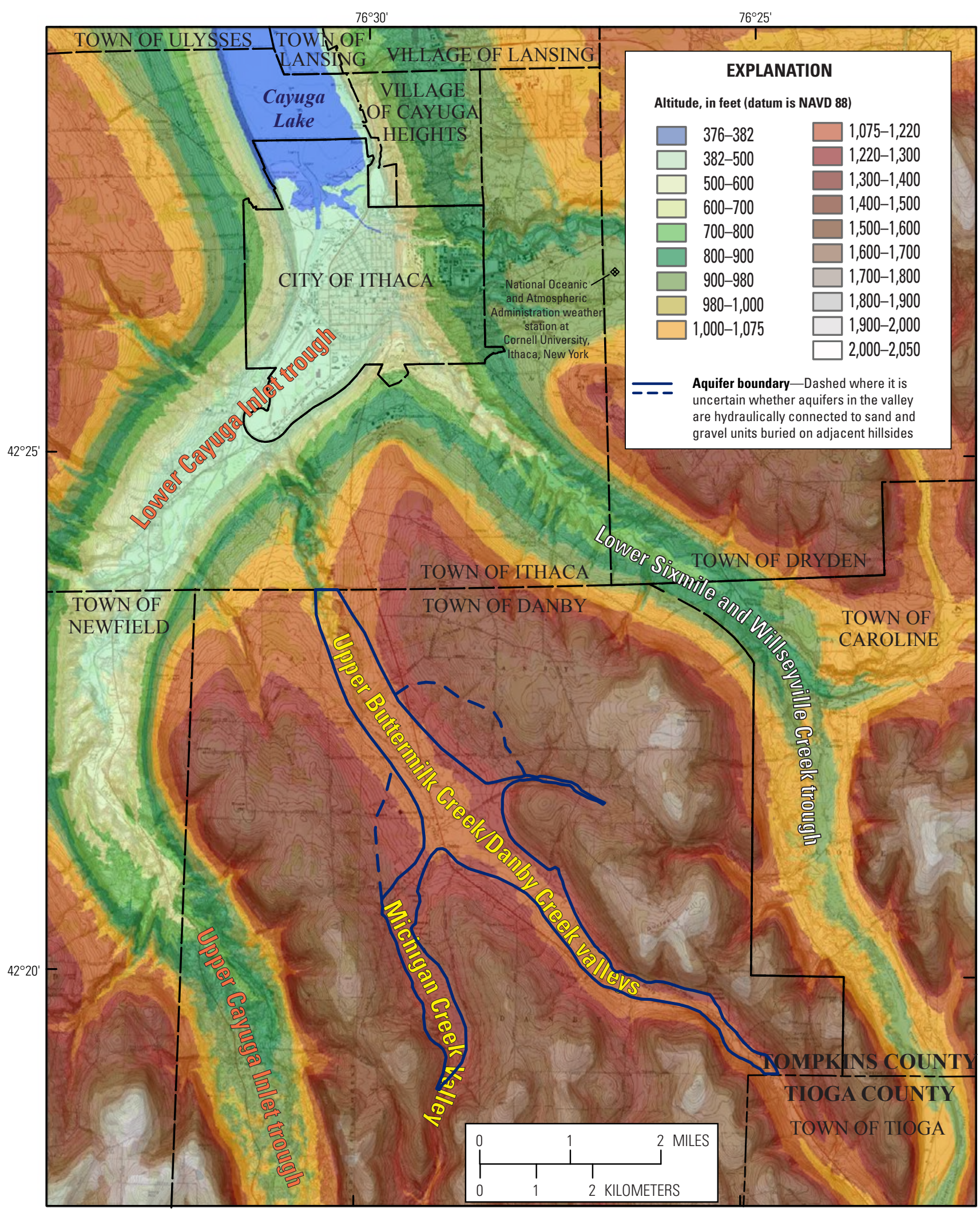

Base from U.S. Geological Survey, Seamless Data Distribution System, 1:24,000 accessed in 2008 at http://seamless.usgs.gov/

Universal Transverse Mercator projection, zone 18

Figure 4. Shaded relief and boundary of stratified-drift aquifer study area in the upper Buttermilk Creek and Danby Creek Valleys, Tompkins County, New York. 
well data include previous U.S. Geological Survey (USGS) groundwater studies, the USGS National Water Information System (NWIS), and well records obtained from the New York State Department of Environmental Conservation (NYSDEC) Water Well Drillers Registration Program, and seven test wells that were drilled during this project.

At selected wells, the altitudes of water-level measuring points, which are typically the tops of the well casings, were determined to $0.01 \mathrm{feet}(\mathrm{ft}$ ) using standard surveying techniques (Kenney, 2010). Elsewhere, altitudes of land surface at wells were estimated using light detection and ranging (lidar) technology and 1:24,000 scale topographic contour maps that were accurate to $0.5 \mathrm{ft}$ and $5 \mathrm{ft}$, respectively. Depths to water below the measuring points were then converted to altitudes, which were used to construct maps of the water table and potentiometric surface of the unconfined and confined aquifers.

\section{Streamflow Measurements, Water Sampling, and Water Analysis}

Streamflow was measured at 21 sites in the Buttermilk Creek and Danby Creek drainage basins from July 31 to August 4, 2008, using an USGS pygmy current meter. Samples were collected at 6 of the 21 streamflow sites. Streamflow measuring techniques are described by Rantz and others (1982).

Surface-water samples were collected at seven sites in the study area. The samples were analyzed for inorganic constituents and nutrients at the USGS National Water Quality Laboratory (NWQL) in Denver, Colorado. Field measurements of $\mathrm{pH}$, specific conductance, dissolved oxygen, and water temperature were also recorded during sample collection. The samples were collected and processed by methods described in the USGS manual for the collection of water-quality data (U.S. Geological Survey, variously dated).

Groundwater-sample collection and processing followed standard USGS procedures as documented in the National Field Manual for the Collection of Water-Quality Data (U.S. Geological Survey, variously dated). Groundwater samples were collected from 12 wells in the study area; of these samples, 8 were collected during 2007-08 and were analyzed for inorganic constituents (common ions and trace elements) and nutrients at the NWQL. Field measurements of $\mathrm{pH}$, specific conductance, dissolved oxygen, and water temperature were also measured during sample collection. Additionally, in response to concerns about natural-gas drilling, four groundwater samples were collected (background water-quality data) during 2010 and were analyzed for chemical constituents associated with gas drilling and (or) deep groundwater systems. Analytes included bromide, radiochemical constituents (gross alpha and gross beta), methane, and other dissolved gases, in addition to many of the constituents analyzed for in the 2007-08 samples.
Six groundwater samples were from test wells drilled for this study, five were from domestic wells, and one was from the well that supplies water to the Danby Town Hall. For the test wells, a stainless-steel submersible pump was used to purge the well of 5 to 10 casing volumes of water before collecting the water samples. The domestic wells and the town hall well were sampled after 20 minutes of pumping (until at least five casing volumes of well water had passed the sampling point); then, a raw-water spigot between the well and the pressure tank was opened, and the water was allowed to run for several more minutes to flush the spigot. Samples were collected from the raw-water spigot to avoid all watertreatment systems and to ensure that the water collected was representative of the water in the aquifer.

\section{Seismic-Refraction Surveys}

Seismic-refraction surveys were conducted at three sites and HVSR ambient-noise seismic surveys were conducted at 5 sites in the study area. Seismic-refraction techniques used in this study are described by Haeni (1988). The seismicrefraction survey method measures the time it takes for a compressional sound wave to travel down through geologic units and back up to detectors (geophones) on land surface. For this investigation, a series of 12 geophones, spaced 50 or $100 \mathrm{ft}$ apart, were inserted into the ground and the arrival times of compressional waves generated by explosives were recorded and plotted as a function of "source-togeophone" distances. A two-layer (saturated unconsolidated sediments and bedrock surface) or three-layer (unsaturated unconsolidated sediments, saturated unconsolidated sediments, and bedrock surface) boundary-formula computer analysis (Scott and others, 1972) was used to calculate depths to the bedrock surface.

The HVSR ambient-noise seismic method was also used to estimate unconsolidated sediment thickness and map the bedrock surface where the use of seismic refraction was not feasible. The HVSR ambient-noise seismic method uses a single, broad-band three-component seismometer to record ambient seismic noise. The ratio of the averaged horizontal-to-vertical frequency spectrum is used to determine the fundamental site resonance frequency, which can be interpreted using regression equations to estimate sediment thickness and depth to bedrock (Lane and others, 2008).

\section{Geology}

Geologic materials in the Town of Danby consist of consolidated sediments (sedimentary bedrock) and unconsolidated sediments (unstratified and stratified glacial drift, alluvium, and swamp deposits). In most places, bedrock is covered by unconsolidated sediments. However, in some places, bedrock crops out at land surface, such as on hilltops, on upper parts of over-steepened valley walls, and in some 
Geohydrology and Water Quality, Stratified-Drift Aquifers, Upper Buttermilk Creek and Danby Creek Valleys, N.Y.

stream channels that have incised through the unconsolidated sediments and flow on bedrock.

\section{Bedrock}

Bedrock in the Town of Danby consists of sedimentary rocks (shale, siltstone, fine-grained sandstone, and limestone, fig. 5) of that were deposited in ancient seas during the Upper Devonian Period from 359.2 to 385.3 million years ago (U.S. Geological Survey Geologic Names Committee, 2010; Fisher and others, 1970; Isachsen and others, 1991; Zambito IV and others, 2007; and Karig and Elkins, 1986). The rocks were uplifted during the end of the Upper Devonian and the Mississippian Periods, which formed the Appalachian Plateau; the northern part of the plateau extends into southern and eastern New York State (fig. 2). About 300 million years ago (Pennsylvanian Period), the African plate began to collide with the North American plate (Isachsen and others, 1991) and the compressional stresses from the collision resulted in gentle folding of the rock units and faulting (both thrust and shear faults; fig. 5; Murphy, 1981; Podwysocki and others, 1982). The plateau was subsequently dissected by streams and eroded by glaciers, resulting in a region dominated by hills and valleys. At present, the rock units have a regional dip to the south at about 40 to $50 \mathrm{ft}$ per mile (Williams and others, 1909); however, superimposed on the south-dipping rocks are gentle folds whose anticline and syncline axes trend roughly east to west (fig. 5). Because of the folds, there are local areas with reversal of dip direction (gentle dips to the north) and southward dipping slopes that have greater than the average regional dip of 40 foot per mile ( $\mathrm{ft} / \mathrm{mi})$.

\section{Glacial History}

The study area has undergone several glaciations during the Pleistocene Epoch, commonly referred to as the Ice Age, which began 2.6 million years ago and ended 11,850 years before present (uncalibrated radiocarbon years; 13,700 calibrated calendar years; Fullerton, 1980; U.S. Geological Survey Geologic Names Committee, 2010).

The last major glacial episode to affect the study area was during late Wisconsin time when the Laurentide Ice Sheet flowed from Canada into New York State. By about 23,000 years before present, the ice covered central New York and extended as far south as northern Pennsylvania (Muller and Calkin, 1993). The last ice to affect the study area was the Valley Heads Moraine re-advance into central New York (Muller and Calkin, 1993). At the terminus of the Valley Heads ice, an end moraine was deposited that loops across central and western New York (fig. 2). A segment of the end moraine crosses the study area in the Danby Creek valley (fig. 6). Valley Heads ice left the study area about 14,400 years ago (Cadwell and Muller, 2004).

\section{High-Altitude Valleys Little Affected by Ice Scour}

Relatively low-altitude valleys that were generally aligned in the direction of glacial flow, such as the lower Sixmile Creek and Willseyville Creek valleys and the Cayuga Inlet valley (figs. 3 and 4), were preferential avenues for ice flow and were severely eroded. These severely eroded valleys were transformed into troughs. These troughs are wider and much deeper than other valleys, with U-shaped transverse valley profiles and smooth, planar bedrock walls. Each trough formerly contained a bedrock col (a high, narrow pass or saddle between watersheds) that was lowered and displaced by ice erosion (Miller and Karig, 2010; Kappel and Miller, 2003). Later, these troughs became filled with 200 to more than $300 \mathrm{ft}$ of glacial and postglacial sediments.

In contrast, relatively high-altitude valleys, such as upper Buttermilk Creek and Danby Creek valleys, underwent much less scour and deposition of sediment than relatively loweraltitude valleys such as in the Cayuga Inlet trough and the lower Sixmile Creek and Willseyville Creek trough, which surround the study area to the west, north, and east (figs. 3 and 4). Scouring by ice was less extensive in high-altitude valleys because the ice was thinner and forces of erosion were less than in lower-altitude valleys. Relief between valley floor and adjacent hilltops in the upper Buttermilk Creek and Danby Creek valleys typically ranges from 400 to $500 \mathrm{ft}$ whereas relief in the Cayuga Inlet trough and the lower Sixmile Creek and Willseyville Creek trough typically ranges from 800 to $1,000 \mathrm{ft}$. In the upper Buttermilk Creek and Danby Creek valleys, well records and seismic data indicate that the thickness of stratified-drift deposits generally ranges from 85 to $150 \mathrm{ft}$, which is one-half as much as that in the loweraltitude valleys.

\section{Wisconsin Deposits in the Study Area}

The unconsolidated deposits in the upper Buttermilk and Danby Creek Basins contain glacial drift that consists of unstratified drift (till) and stratified drift (glaciolacustrine and glaciofluvial) sediments that were deposited during the Wisconsin Stage of the Pleistocene Epoch; postglacial alluvium and swamp deposits that were deposited during the Holocene Epoch. The areal distribution of surficial deposits in the study area is shown in figure 6 and the subsurface stratigraphy along four geohydrologic-section lines is shown in figures 7 through 10 .

In the study area, till composes the largest portion of the drift in the uplands and in the valleys (fig. 6). Till is a poorly sorted, unstratified mixture of rocks embedded in a matrix consisting chiefly of clay, silt, and fine sand units (geologic units tl, ground-moraine deposits in the uplands and tv, ground-moraine deposits in the valley fill, fig. 6), and was deposited directly from glacial ice rather than transported by meltwater. In the uplands, the rocks in till range in size from 

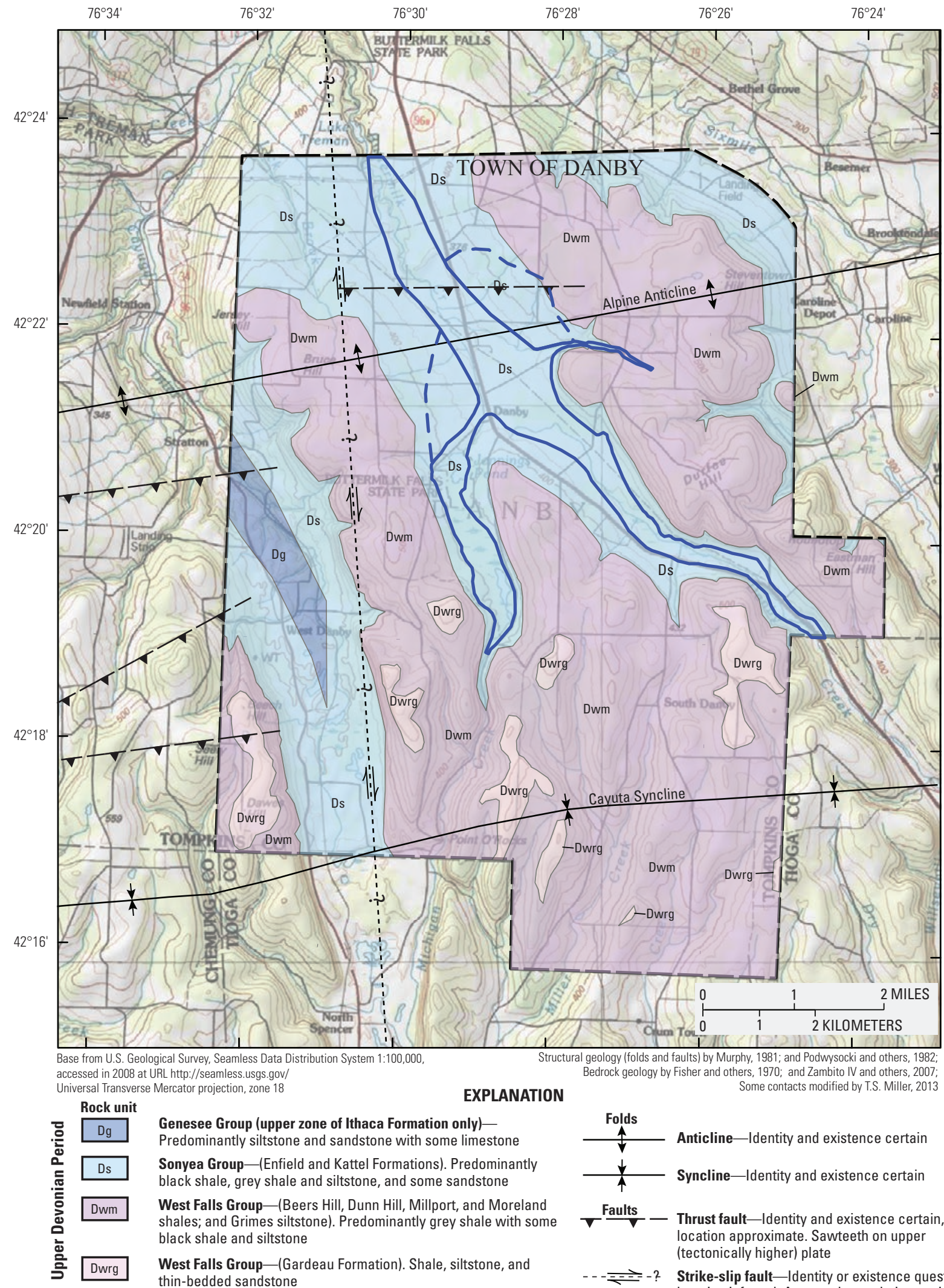

$\checkmark \frac{\text { Faults }}{\checkmark}$ - Thrust fault—Identity and existence certain, location approximate. Sawteeth on upper (tectonically higher) plate

$-\Longrightarrow-$ ? Strike-slip fault-Identity or existence questionable, location inferred. Arrows show relative motion

Aquifer boundary-Dashed where it is uncertain whether aquifers in the valley are hydraulically connected to sand and gravel units buried on adjacent hillsides

Figure 5. Bedrock and structural geology of the Town of Danby, Tompkins County, New York. 


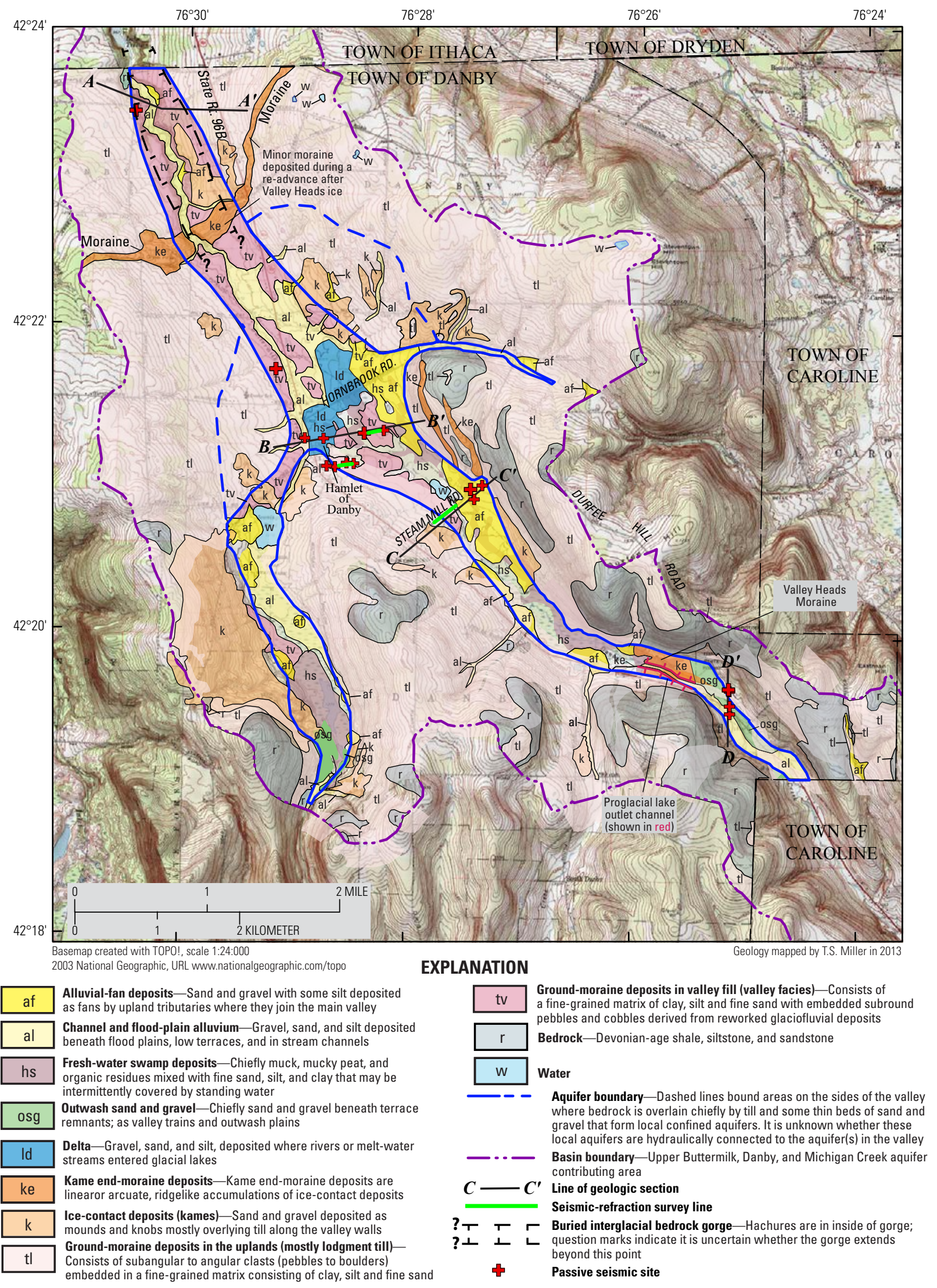

Figure 6. Surficial geology of upper Buttermilk Creek, Danby Creek, and Michigan Creek Basins, Town of Danby, Tompkins County, New York. 
fine pebbles to boulders and are predominantly subangular to angular, flat platy clasts of local siltstone and shale. In the valleys, the rocks in till are subangular to rounded and range in size from fine pebbles to cobbles, consisting mostly of local siltstone and shale but also includes many glacial erratics (rocks such as sandstone, limestone, igneous, and metamorphic rocks). In most places in the uplands, till is the only deposit that overlies the bedrock (fig. 6). However, on some hilltops and over steepened hillsides in the Danby Creek valley, till may be absent and bedrock crops out at land surface (fig. 6). Till has low permeability (hydraulic conductivity is low).

Stratified drift (glaciolacustrine and glaciofluvial deposits) in the study area is present chiefly in valleys and in some places along the lower flanks of valley walls (figs. 6 through 10). Stratified drift consists of layered and sorted sediments. In the study area, fine-to-medium grained stratified drift consists of clay, silt, and fine-to-medium-grained sand of glaciolacustrine origin (lake-bottom deposits) that were laid down where heavily sediment-laden meltwaters and upland streams emerged into former small lakes such as proglacial lakes or lakes that formed in small basins and depressions in the upper Buttermilk and Danby Creek valleys. The mediumto-coarse grained stratified drift near the Hamlet of Danby that consists of pebbly sand with some silt was deposited at a delta along the edge of a former shallow glacial lake that once extended from the moraine in the northern part of upper Buttermilk valley to the Hamlet of Danby (figs. 6 and 8).

Coarse-grained stratified drift (sand and gravel) consists of layered and sorted glaciofluvial deposits (outwash sand and gravel, kames, and kame-end moraine) that were deposited by glacial meltwater streams that flowed on top, beneath, or within a glacier. Holocene fluvial deposits that consist of channel and flood-plain alluvium, and alluvial-fan deposits (fig. 6) were deposited by post-glacial streams. Kame endmoraine deposits tend to be poorly sorted and consist of silt, sand, and gravel and, in some places, of till. The kame-end moraine in the northern part of the study area forms a 30 to $40 \mathrm{ft}$ high arcuate ridge where it crosses the upper Buttermilk valley and a 10 to $20 \mathrm{ft}$ high ridge where it extends up both sides of the valley walls (fig. 6).

In the northern part of the study area (upper Buttermilk Creek valley), the glaciofluvial deposits in the valley are typically overlain by till (figs. 7 and 8), but in some places, the glaciofluvial deposits crop out at land surface, such as where a kame-end moraine crosses the valley and where several icecontact kame deposits crop out along the edges of the valley and on the lower flanks of hillsides (fig. 6). In the northern part of the study area, there may be one or two undifferentiated sand and gravel units (figs. 7 and 8). Near the northern boundary of the Town of Danby, well records indicate that there is only one sand and gravel unit - this unit is a basal unit 10 to $20 \mathrm{ft}$ thick that overlies bedrock in the upper Buttermilk Creek buried gorge (fig. 7). Across the upper Buttermilk Creek valley and near the Hamlet of Danby, there are two undifferentiated sand and gravel units and one glaciolacustrine (delta) pebbly sand unit. The undifferentiated sand and gravel units include a basal sand and gravel unit on top of bedrock in the eastern part of the valley and an upper buried sand and gravel unit; each of these units range in thickness from 5 to $10 \mathrm{ft}$ (fig. 8). The surficial glaciolacustrine unit is composed of deltaic-pebbly sand with some silt that ranges in thickness from 10 to $25 \mathrm{ft}$ (fig. 8).

Holocene-age alluvial deposits in the northern part of the study area are typically thin, ranging from 1 to $10 \mathrm{ft}$ thick in the stream channels and flood plains. However, the alluvial deposits are locally thicker (10 to $25 \mathrm{ft}$ thick) at alluvial fans, such as the large fan deposit at Hornbrook Road east of the Hamlet of Danby (fig. 6). Large alluvial fans can form local small unconfined aquifers.

In the southern part of the study area (Danby Creek valley), the coarse-grained stratified drift (sand and gravel) is composed of glaciofluvial deposits (outwash and isolated kames along the lower flanks of hillsides) and Holocene alluvial deposits (fluvial channel, floodplain, and fan deposits; figs. 6, 9, and 10). However, it is unknown whether coarsegrained stratified drift underlies the large wetland that occupies a large part of the valley (fig. 6) because there are no subsurface data in this area. Where Steam Mill Road crosses Danby Creek valley in the southern part of the study area, the alluvial fan deposits ranges in thickness from 20 to $35 \mathrm{ft}$ and forms a local unconfined aquifer (figs. 6 and 9). Where Durfee Hill Road crosses Danby Creek valley in the southern part of the study area, the outwash and alluvial channel and floodplain sand and gravel deposits range in thickness from 30 to $40 \mathrm{ft}$ (figs. 6 and 10).

\section{Geohydrology of the Stratified-Drift Aquifer System}

Characterization of the stratified-drift aquifer system in the Buttermilk and Danby Creek valleys in the Town of Danby, Tompkins County included describing the (1) aquifer type (confined or unconfined), (2) aquifer framework, (3) groundwater-flow system, including water levels and recharge and discharge conditions, and (4) water quality of surface water and groundwater. Data used to characterize the aquifer type and the geologic framework of the aquifers were obtained mostly from well records and geologist's logs of eight test wells drilled at five sites during this study (appendix 2). The locations of 140 wells in the Town of Danby are shown in figure 11. Records of these wells and construction details for the test wells drilled for this study are in appendix 1 and 2, and the range, mean, and median of well depths and reported well yields are summarized in table 1 . 


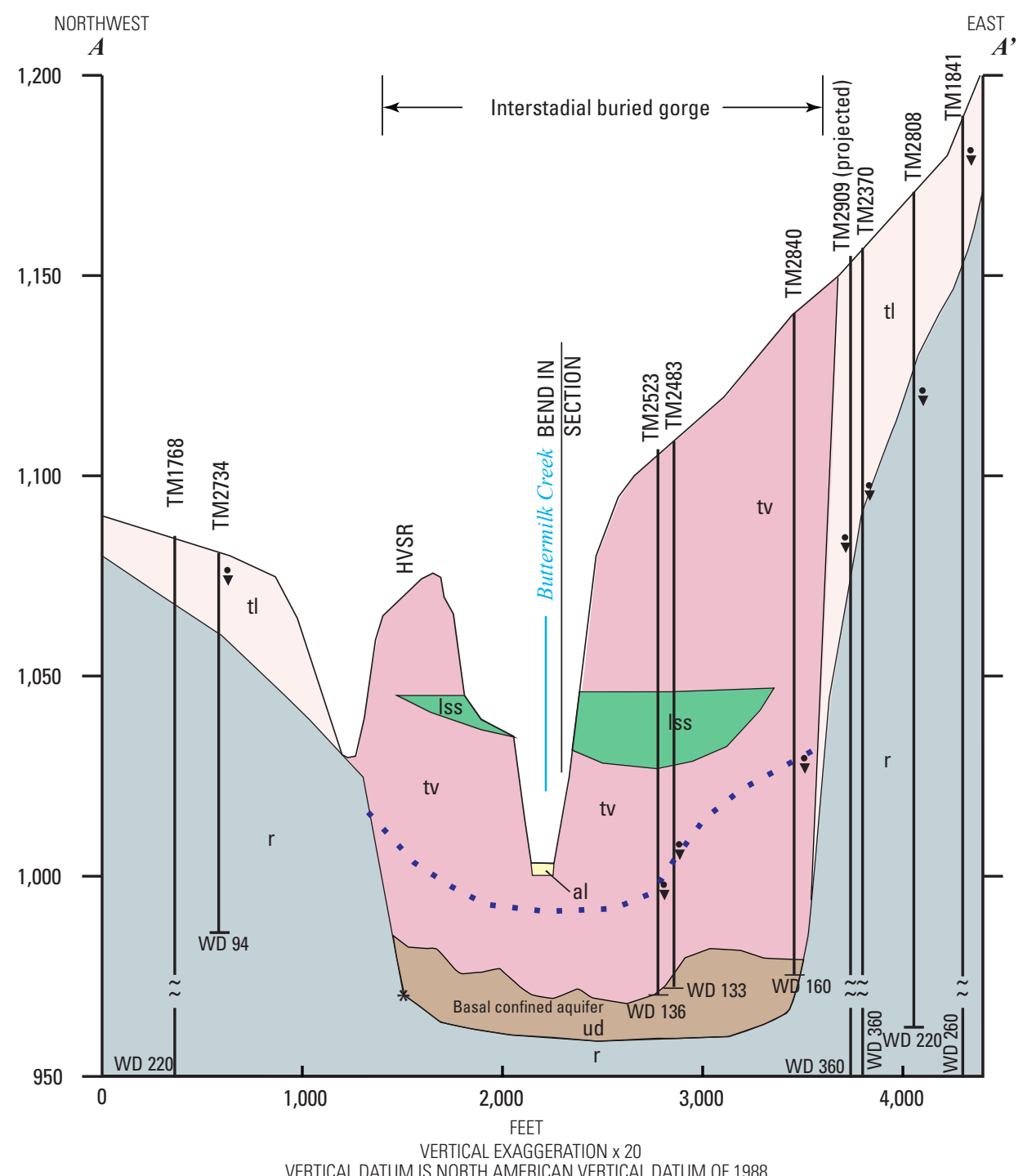

\section{Alluvial deposits of Holocene age}

Channel and flood-plain alluvium-Gravel, sand, and silt deposited by recent streams. Deposits are found beneath flood plains, low terraces, and in stream channels

\section{Glaciolacustrine deposits of Wisconsin age}

Iss Silt and sand-Chiefly off-shore and near-shore deposits of former glacial and postglacial lakes; some deposits are in small separate basins. The deposits are thin and discontinuous in some areas

\section{Glaciofluvial deposits of Wisconsin age}

ud Undifferentiated sand and gravel (unknown origin) - Buried deposits whose origin is unknown. Forms confined aquifers where overlain by till or lacustrine silt and clay

\section{Till of late Wisconsin age}

tl Ground-moraine deposits in the uplands (mostly lodgment till)Consists of subangular to angular clasts (pebbles to boulders) derived in large part from local bedrock that became embedded in a fine-grained matrix consisting of clay, silt, and fine sand

tv Ground-moraine deposits in valley fill (valley facies) - Consists of subround to round clasts (pebbles to cobbles) derived in large part from reworked glaciofluvial deposits that became embedded in a fine-grained matrix consisting of clay, silt, and fine sand. Forms a confining unit where it overlies sand and gravel units

EXPLANATION

Devonian-age rocks

$r \quad$ Bedrock-Devonian-age shale, siltstone, and sandstone

\section{Geohydrologic symbols}

- - - Potentiometric surface-Shows altitude of water level in cased wells finished in the confined aquifer. Datum is NAVD 88

$-\quad$ Water level-Static-water level in well (well may be finished in bedrock aquifers, or the upper confined, lower confined, or unconfined aquifers)

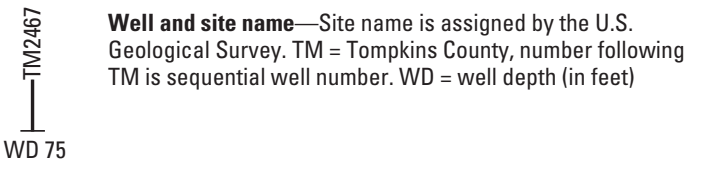

$\gtrless \quad$ Horizontal-to-vertical ambient-noise seismic measurementAsterisk denotes computed depth to bedrock

Figure 7. Geohydrologic section $A-A^{\prime}$ across the northern part of upper Buttermilk Creek valley, Town of Danby, Tompkins County, New York. 


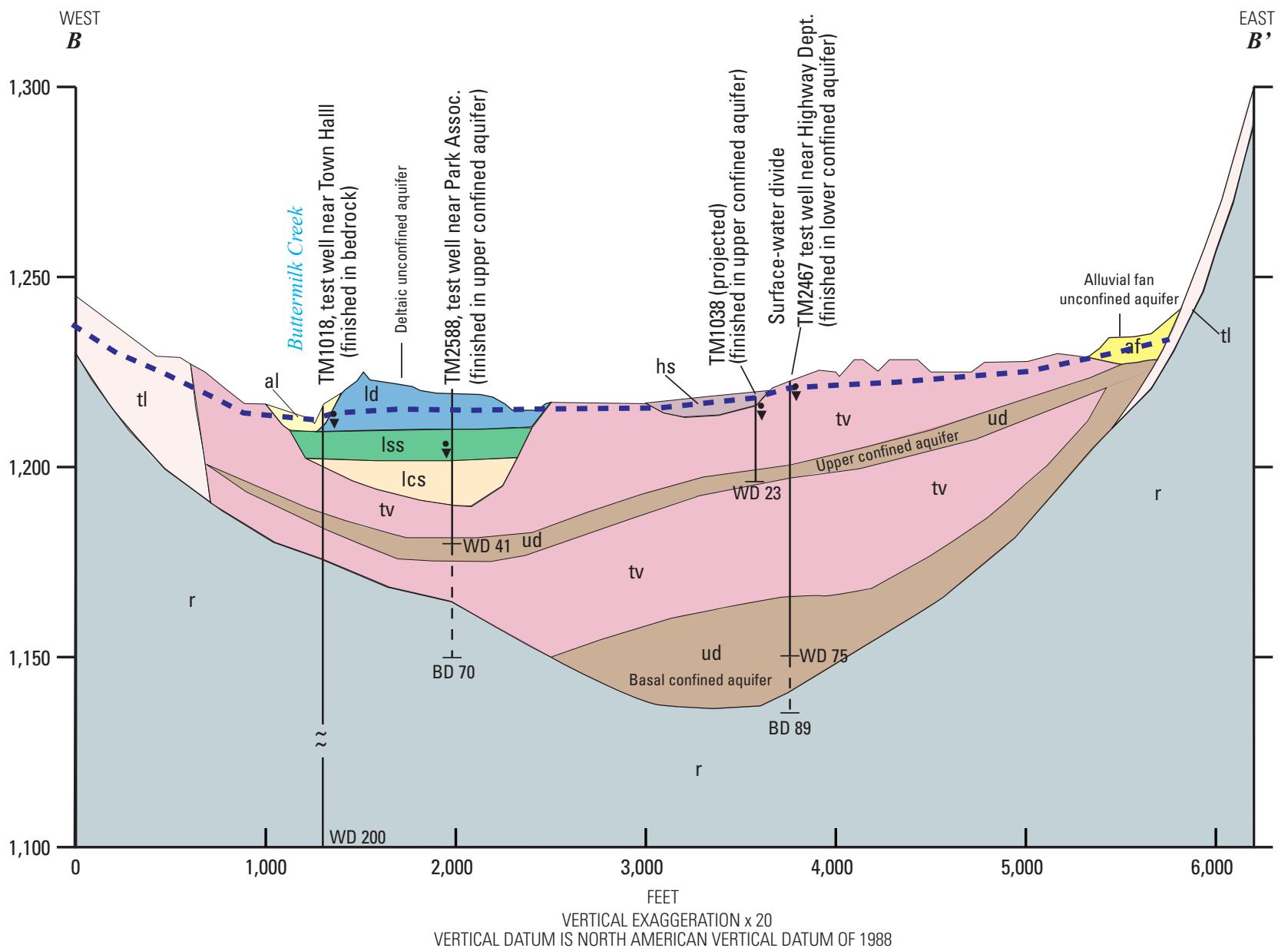

\section{EXPLANATION}

Alluvial deposits of Holocene age

hs Fresh-water swamp deposits-Chiefly muck, mucky peat, and organic residues mixed with fine sand, silt, and clay that may be intermittently covered by standing water

af Alluvial-fan deposits-Sand and gravel with some silt deposited as fans by upland tributaries where they join the main valley. May form local unconfined aquifers

al Channel and flood-plain alluvium-Gravel, sand, and silt deposited by recent streams. Deposits are found beneath flood plains, low terraces, and in stream channels

Glaciolacustrine deposits of Wisconsin age

Id Delta-Pebbly sand and silt, deposited where upland streams or meltwater streams entered a glacial lake

Silt and sand-Chiefly off-shore and near-shore deposits of forme glacial and postglacial lakes; some deposits are in small separate basins. The deposits are thin and discontinuous in some areas.

Ics Clay and silt-Fine-grained sediments that were deposited in forme glacial and postglacial lakes; some deposits settled in small separate basins. The deposits are thin and discontinuous in some areas

Glaciofluvial deposits of Wisconsin age

ud Undifferentiated sand and gravel (unknown origin) — Buried deposits whose origin is unknown. Forms confined aquifers where overlain by till or lacustrine silt and clay

\section{Till of late Wisconsin age}

$\mathrm{tl}$ Ground-moraine deposits in the uplands (mostly lodgment till)-Consists of subangular to angular clasts (pebbles to boulders) derived in large part from local bedrock that became embedded in a fine-grained matrix consisting of clay, silt and fine sand

tv Ground-moraine deposits in valley fill (valley facies)Consists of subround to round clasts (pebbles to cobbles) derived in large part from reworked glaciofluvial deposits that became embedded in a fine-grained matrix consisting of clay, silt and fine sand. Forms a confining unit where it overlies sand and gravel units

\section{Devonian-age rocks}

$r \quad$ Bedrock-Devonian-age shale, siltstone, and sandstone

Geohydrologic symbols

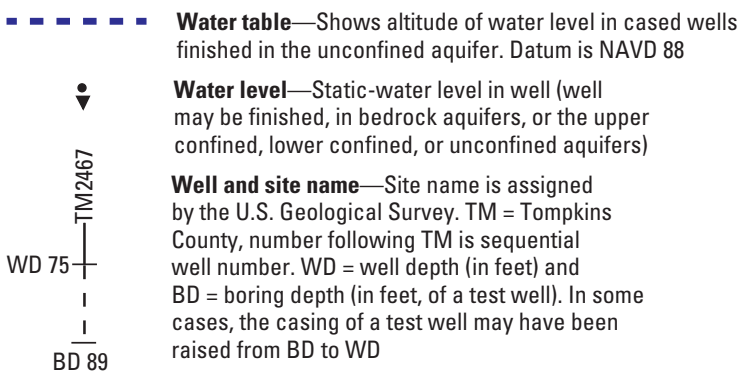

Figure 8. Geohydrologic section $B-B^{\prime}$ across the headwaters of upper Buttermilk Creek and Danby Creek valleys near the hamlet of Danby, Town of Danby, Tompkins County, New York. 


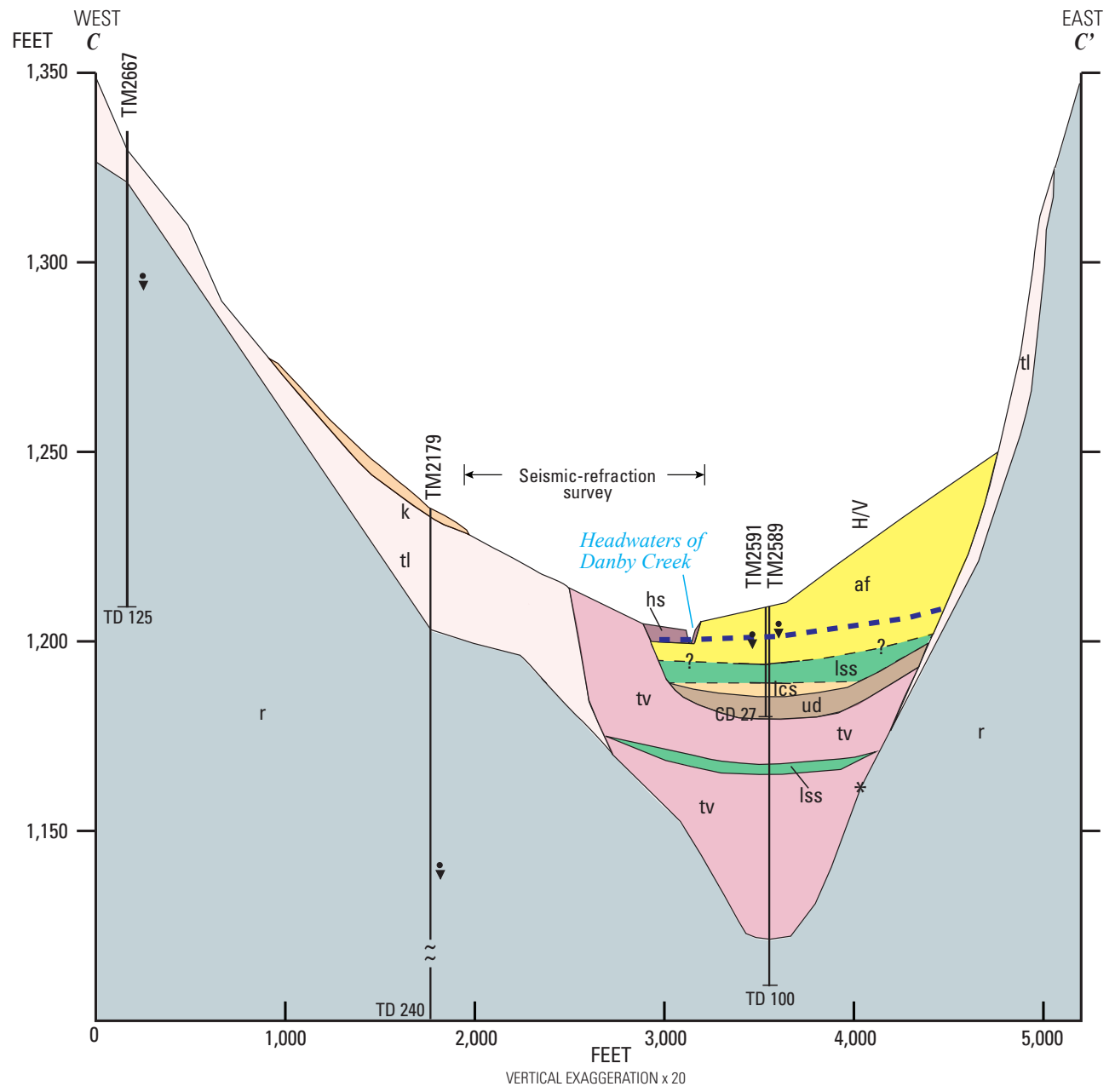

VERTICAL DATUM IS NORTH AMERICAN VERTICAL DATUM OF 1988

EXPLANATION

Alluvial deposits of Holocene age

af Alluvial-fan deposits-Sand and gravel with some silt deposited as fans by upland tributaries where they join the main valley. May form local unconfined aquifers

\section{Swamp deposits of Holocene age}

hs Fresh-water swamp deposits-Chiefly muck, mucky peat, and organic residues mixed with fine sand, silt, and clay that may be intermittently covered by standing water. The deposits are on former lake beds, in abandoned glacial melt-water channels and sluiceways, and other shallow poorly-drained depressions

\section{Glaciolacustrine deposits of Wisconsin age}

k Ice-contact deposits (kames) - Sand and gravel deposited as mounds and knobs mostly overlying till along the valley walls

Iss Silt and sand-Chiefly off-shore and near-shore deposits of former glacial and postglacial lakes; some deposits are in small separate basins. The deposits are thin and discontinuous in some areas

Ics Clay and silt-Fine-grained sediments that were deposited in former glacial and postglacial lakes; some deposits settled in small separate basins. The deposits are thin and discontinuous in some areas

\section{Glaciofluvial deposits of Wisconsin age}

ud Undifferentiated sand and gravel (unknown origin)—Buried deposits whose origin is unknown. Forms confined aquifers where overlain by till or lacustrine silt and clay

Till of late Wisconsin age

tl Ground-moraine deposits in the uplands (mostly lodgment till)Consists of subangular to angular clasts (pebbles to boulders) derived in large part from local bedrock that became embedded in a fine-grained matrix consisting of clay, silt and fine sand
Till of late Wisconsin age, continued

tv Ground-moraine deposits in valley fill (valley facies) - Consists of subround to round clasts (pebbles to cobbles) derived in large part from reworked glaciofluvial deposits that became embedded in a fine-grained matrix consisting of clay, silt and fine sand. Forms a confining unit where it overlies sand and gravel units

Devonian-age rocks

$r \quad$ Bedrock—Devonian-age shale, siltstone, and sandstone

Geohydrologic symbols

- = - = - Water table - Shows altitude of water level in cased wells finished in the unconfined aquifer. Datum is NAVD 88

- Water level-Static-water level in well (well may be finished in bedrock aquifers, or the upper confined, lower confined, or unconfined aquifers)

Well and site name-Site name is assigned by the U.S. Geological

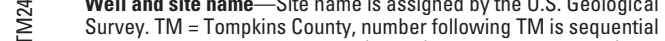

well number. $C D=$ casing depth (in feet) and TD = total depth (in

$\perp$ feet) of an open-hole well finished in bedrock or of a test well

$\mathrm{CD} 75$

TD 89

I Horizontal-to-vertical ambient-noise seismic measurement-

* Asterisk denotes computed depth to bedrock

Figure 9. Geohydrologic section $C-C^{\prime}$ across Danby Creek valley, along Steam Mill Road, Town of Danby, Tompkins County, New York. 


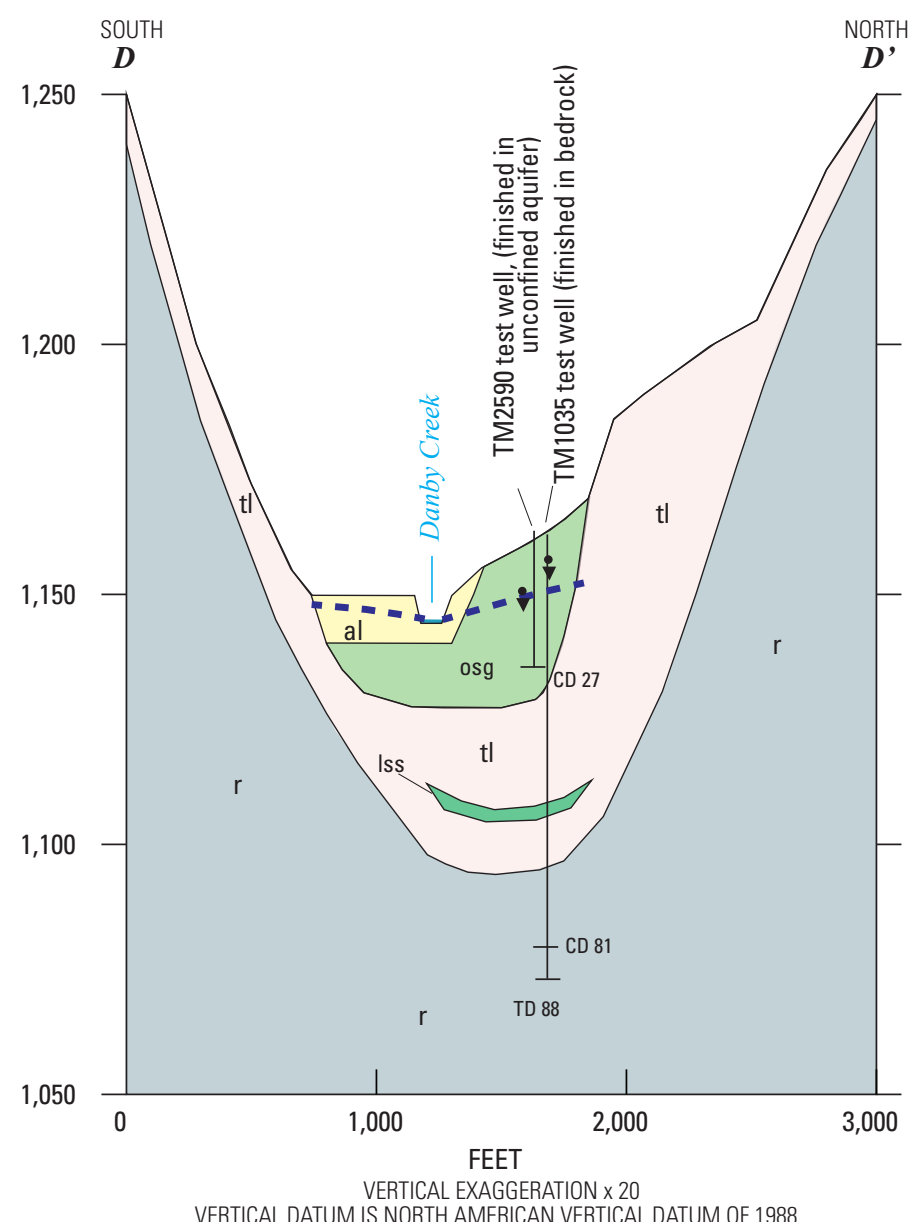

EXPLANATION

\section{Alluvial deposits of Holocene age}

al

Channel and flood-plain alluvium-Gravel, sand, and silt deposited by recent streams in the valleys. Deposits are found beneath flood plains, low terraces, and in stream channels

Glaciofluvial deposits of Wisconsin age

osg Outwash sand and gravel-Chiefly sand and gravel beneath terrace remnants; as valley trains and beneath outwash plains; as fans and aprons; as delta topset beds. Forms the main part of the unconfined aquifer in the valley

\section{Glaciolacustrine deposits of Wisconsin age}

Lacustrine sand-Chiefly off-shore and near-shore deposits of former glacial and postglacial lakes; some deposits are in small separate basins. Extent is unknown elsewhere

\section{Till of late Wisconsin age}

tl Ground-moraine deposits in the uplands (mostly lodgment till)Consists of subangular to angular clasts (pebbles to boulders) embedded in a fine-grained matrix consisting of clay, silt and fine sand

\section{Devonian-age rocks}

$r$ Bedrock-Devonian-age shale, siltstone, and sandstone
Geohydrologic symbols

\section{- - - - - Water table (unconfined aquifer)}

$-\quad$ Water level-Static-water level in well (well may be finished in bedrock, or in the upper unconfined aquifer)

응 Well and site name-Site name is assigned $\sum_{\Sigma} \quad$ by the U.S. Geological Survey. TM = Tompkins County, number following TM is sequential well number. CD = casing depth (in feet) and CD 81 TD = total depth (in feet) of an open-hole well TD 88 finished in bedrock or of a test well (in some cases, the casing of a test well may have been raised from $T D$ to $C D$ )

Figure 10. Geohydrologic section $D-D^{\prime}$ across Danby Creek valley, along Durfee Hill Road, Town of Danby, Tompkins County, New York. 


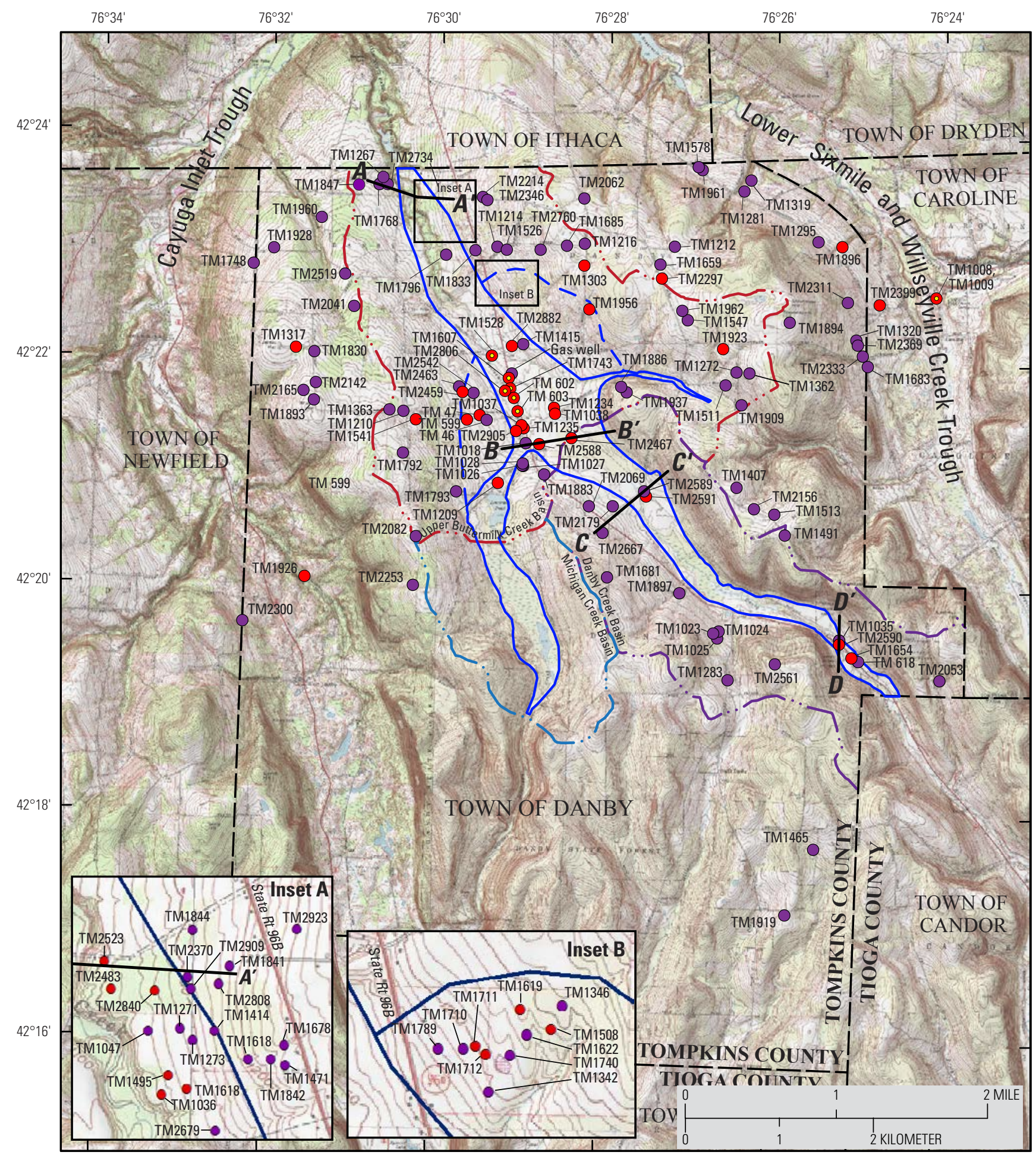

Basemap created with TOPO!, scale 1:24:000

2003 National Geographic, URL www.nationalgeographic.com/topo

Figure 11. Location of wells in the Town of Danby, Tompkins County, New York. 


\section{Aquifer Types}

The unconsolidated sediments in the upper Buttermilk and Danby Creek valleys contain confined and unconfined aquifers and confining layers. The major stratified-drift aquifers in the study area are confined sand and gravel units in the upper Buttermilk Creek valley and an unconfined aquifer in the southern part in the Danby Creek valley (fig. 12). In addition to these major aquifers, alluvial fans (fig. 6) form thin and discontinuous unconfined sand and gravel aquifers in several localities (fig. 12). Aquifers are composed of sediments of sufficient permeability (moderate to high hydraulic conductivity) that can store and yield usable amounts of water to wells. Moderate hydraulic conductivity is defined from 10 to 100 feet per day (ft/d) and high hydraulic conductivity is greater than $100 \mathrm{ft} / \mathrm{d}$. In an unconfined aquifer, the water table is at or near atmospheric pressure and is the upper boundary of the aquifer. There were only two wells (TM1654 and TM2590) in the study area that were finished in unconfined aquifers (fig. 12). The two wells were 27 and $41 \mathrm{ft}$ deep and reported well yields were 10 and 20 gallons per minute (gal $/ \mathrm{min}$ ).

Confining layers are made up of poorly permeable sediments (low hydraulic conductivity) that prevent groundwater from rapidly moving through these layers. In the study area, the confining layers consist of mostly of till and some fine-grained glaciolacustrine sediments (figs. 7 through 10) clay, silt and fine sand.

A confined aquifer (also known as an artesian aquifer) is between confining layers and is composed of sediments and bedrock of sufficient permeability that it is able to store and yield usable amounts of water to wells. In a confined aquifer, the potentiometric surface is, by definition, always above the top of the aquifer. When a confined aquifer is tapped by a well, water in the casing is forced up to its potentiometric altitude. If the hydraulic pressure in the confined aquifer is

\section{EXPLANATION}

\begin{tabular}{|c|c|}
\hline & $\begin{array}{l}\text { Aquifer boundary-Dashed lines bound areas } \\
\text { on the sides of the valley where bedrock is } \\
\text { overlain chiefly by till and some thin beds of } \\
\text { sand and gravel that form local confined } \\
\text { aquifers. It is unknown whether these local } \\
\text { aquifers are hydraulically connected to the } \\
\text { aquifer(s) in the valley. }\end{array}$ \\
\hline & $\begin{array}{l}\text { Basin boundary-Variously colored. Upper } \\
\text { Buttermilk, Danby, and Michigan Creek aquifer } \\
\text { contributing area }\end{array}$ \\
\hline$-D^{\prime}$ & Line of geologic section \\
\hline TM1528 & $\begin{array}{l}\text { Well finished in stratified drift and site name-- } \\
\text { Site name is assigned by U.S. Geological Survey }\end{array}$ \\
\hline TM $603 \odot$ & $\begin{array}{l}\text { Well under flowing-artesian conditions that } \\
\text { is finished in stratified drift and site name-- } \\
\text { Site name is assigned by U.S. Geological Survey }\end{array}$ \\
\hline TM25 & $\begin{array}{l}\text { Well finished in sedimentary rocks (shale, } \\
\text { siltstone, and sandstone) and site name-- } \\
\text { Site name is assigned by U.S. Geological Survey }\end{array}$ \\
\hline
\end{tabular}

great enough, it may cause the well to flow above land surface, in which case, the well is referred to as a flowing artesian well. Wells that tap confined stratified-drift aquifers (glaciofluvial unit ud, figs. 7 through 9) in the Town of Danby ranged from 23 to $160 \mathrm{ft}$ deep and mean and median well depths were $74 \mathrm{ft}$ and $70 \mathrm{ft}$, respectively (table 1). Reported yields for wells finished in confined stratified-drift aquifers ranged from 3 to $50 \mathrm{gal} / \mathrm{min}$ and mean and median yields were 16 and 15 , respectively (table 1 ).

In the Town of Danby, wells that tap the Devonian-age bedrock (mostly shale, siltstone, and sandstone) ranged from 50 to $420 \mathrm{ft}$ deep and mean and median well depths were $202 \mathrm{ft}$ and $183 \mathrm{ft}$, respectively (table 1). Reported yields for wells finished in bedrock aquifers ranged from 0.1 to $30 \mathrm{gal} / \mathrm{min}$ with mean and median yields of 6 and $4 \mathrm{gal} / \mathrm{min}$, respectively (table 1).

\section{Upper Buttermilk Creek Valley}

In the northern part of upper Buttermilk Creek valley, near the northern boundary of the Town of Danby, well records indicate that only one sand and gravel aquifer, a confined basal unit that is 10 to $20 \mathrm{ft}$ thick and overlies bedrock at the valley bottom (fig. 7). Several domestic wells (wells ranged from 109 to $160 \mathrm{ft}$ deep) in the central part of the valley tap this aquifer. Water-well drillers' logs indicate that well yields range from 8 to $50 \mathrm{gal} / \mathrm{min}$, and averaged $20 \mathrm{gal} / \mathrm{min}$ for the six open-ended wells (6-in. diameter) that tap the confined aquifer in this area. These six wells are under confined conditions (but do not flow above land surface).

In the southern part of upper Buttermilk Creek valley, near the Hamlet of Danby, there are as many as four coarsegrained, stratified-drift geohydrologic units:

1. A thin surficial (unconfined) deltaic pebbly sand and silt unit that ranges from 5 to $10 \mathrm{ft}$ thick (figs. 6 and 8) that was determined from test well TM2588 (well construction log in appendix 2, fig. 2-1).

2. A surficial (unconfined) alluvial fan deposit that is on the east side of the valley (figs. 6 and 8).

3. An upper sand and gravel unit (confined above and below by till) that ranges from 5 to $10 \mathrm{ft}$ thick (fig. 8).

4. A basal confined sand gravel unit (confined above by till and below by bedrock) that was determined at test well TM2467 (well construction log in appendix 2, fig. 2-2) at the surface-water divide between Buttermilk Creek and Danby Creek Basins in the central part of the valley (figs. 7, 8, and 12).

The thin surficial (unconfined) deltaic pebbly sand unit had been tapped by shallow dug wells, but this unit is not considered to be a reliable aquifer because it is thin and typically becomes unsaturated during dry periods. Well data are not available at the alluvial fan in the eastern part of the valley (near Hornbrook Road); therefore, the geohydrologic condition is mostly unknown. The confined aquifers in the southern part of upper Buttermilk Creek valley do not flow above land surface in most areas except along a 
Table 1. Range, mean, and median of well depths and reported well yields in the Town of Danby, New York.

[ft, feet; gal/min, gallons per minute. Data reported from water well drillers logs and stored in USGS National Water Information System computer data base accessible at http://waterdata.usgs.gov/ny/nwis/inventory.]

\begin{tabular}{|c|c|c|c|c|c|c|c|c|c|}
\hline \multirow[b]{2}{*}{ Aquifer type } & \multirow[b]{2}{*}{$\begin{array}{l}\text { Number } \\
\text { of wells }\end{array}$} & \multicolumn{3}{|c|}{ Well dephs } & \multirow{2}{*}{$\begin{array}{l}\text { Number } \\
\text { of wells }\end{array}$} & \multicolumn{3}{|c|}{ Reported well yields } & \multirow{2}{*}{$\begin{array}{c}\text { Number of } \\
\text { artesian } \\
\text { flowing } \\
\text { wells }\end{array}$} \\
\hline & & $\begin{array}{c}\text { Range } \\
\text { (ft) }\end{array}$ & $\begin{array}{c}\text { Mean } \\
\text { (ft) }\end{array}$ & $\begin{array}{l}\text { Median } \\
\text { (ft) }\end{array}$ & & $\begin{array}{c}\text { Range } \\
\text { (gal/min) }\end{array}$ & $\begin{array}{c}\text { Mean } \\
\text { (gal/min) }\end{array}$ & $\begin{array}{c}\text { Median } \\
\text { (gal/min) }\end{array}$ & \\
\hline Unconfined sand and gravel & 2 & $27-41$ & 34 & 34 & 2 & $10-20$ & 15 & 15 & 0 \\
\hline Confined sand and gravel & 32 & $23-160$ & 74 & 70 & 30 & $3-50$ & 16 & 15 & 5 \\
\hline Bedrock & 99 & $50-420$ & 202 & 183 & 95 & $0.1-30$ & 6 & 4 & 0 \\
\hline
\end{tabular}

low-altitude corridor adjacent to Buttermilk Creek north of the Hamlet of Danby (figs. 11 and 12). Most domestic wells in the upper Buttermilk Creek valley are completed in these confined aquifers.

\section{Danby Creek Valley}

The aquifer types in Danby Creek valley are variable and depend on location (figs. 3 and 12). The lower (southeastern most) 8,000 ft of Danby Creek valley within the Town of Danby is occupied by a contiguous unconfined surficial aquifer (fig. 12) composed chiefly of sand and gravel (kames, outwash, and alluvium, figs. 6 and 10). The aquifer averages about $800 \mathrm{ft}$ wide. Several domestic wells use this aquifer for water supply. Where Durfee Hill Road crosses Danby Creek valley (fig. 12), test-well records for TM1035 and TM2590 (fig, 10; well construction logs in appendix 2, figs. 2-3) indicate several important features:

1. The surficial sand and gravel deposits are $32 \mathrm{ft}$ thick at that site.

2. The saturated thickness is $20 \mathrm{ft}$.

3. The unconfined aquifer may contain fine-grained lenses, such as silt.

4. A basal confined aquifer was not present.

5. Depth to bedrock was $68 \mathrm{ft}$ (fig. 10).

This aquifer extends southward beyond Tompkins County and into Tioga County where it becomes part of the large aquifer system in the Catatonk Creek drainage basin (fig. 2 of Miller and Pittman, 2012).

There are also several small unconfined units (alluvial fans) along the west and east sides of the valley near Steam Mill Road (figs. 6, 8, 9, and 12). However, subsurface data are not available in these areas to determine the saturated thickness of these alluvial fan deposits.

An upper confined aquifer (confined above and below by till) was determined between depths of 19 and $23 \mathrm{ft}$ at test well TM2467 (fig. 8). This aquifer apparently grades to fine sand between 43 and $46 \mathrm{ft}$ at test well TM2591 near Steam Mill Road (fig. 9; well construction log in appendix 2, fig. 2-4) and between 44 and $48 \mathrm{ft}$ at test well TM1035 at Durfee Hill
Road (fig. 10; well construction log in appendix 2, fig. 2-3). This sand unit is not considered an important aquifer in Danby Creek valley because it is thin ( 3 to $4 \mathrm{ft}$ thick). Water-well drillers in central New York do not typically finish an openend cased well in fine sand because the sand is likely to flow inside the casing and, in some cases, mix with pumped water.

At a nested, test-well site (wells TM2589 and TM2591) at Steam Mill Road, well TM2589 penetrated a shallow 7-ft-thick confined aquifer at depths from 24 to $31 \mathrm{ft}$ (fig. 9). Test well TM2591 (well log in appendix 2, fig. 2-4), an opened-ended cased well finished at depth $27 \mathrm{ft}$, yielded $20 \mathrm{gal} / \mathrm{min}$ during development of the well. Because well data are not available where a large wetland occupies most of the valley floor to the south of the test well TM2591, the presence of aquifers is unknown in that area (fig. 11).

The basal confined aquifer (confined above by till and below by shale) that was identified at test well TM2467 (at the surface-water divide between Buttermilk Creek and Danby Creek Basins, figs. 8 and 12), probably extends southward into Danby Creek valley. However, the basal confined aquifer was absent at test well TM2589 at Steam Mill Road (fig. 9, and well construction log in appendix 2, fig. 2-4), which indicates that the unit pinched out between the divide and Steam Mill Road (fig. 12).

\section{Michigan Creek Valley}

Well data are not available in Michigan Creek valley (fig. 11); therefore, aquifer conditions are unknown. Based on geologic information, the ice-contact sand and gravel deposits (kames) that are on the lower flanks of the west valley wall of Michigan Creek valley (fig. 6) may extend below the wetland in the valley and form an aquifer; however, drilling a well would be difficult because of the wetland (fig. 12).

\section{Bedrock}

Bedrock aquifers (Devonian-age sedimentary rocks, fig. 6) that underlie the Town of Danby are the important sources of drinking water for homeowners in the uplands. 


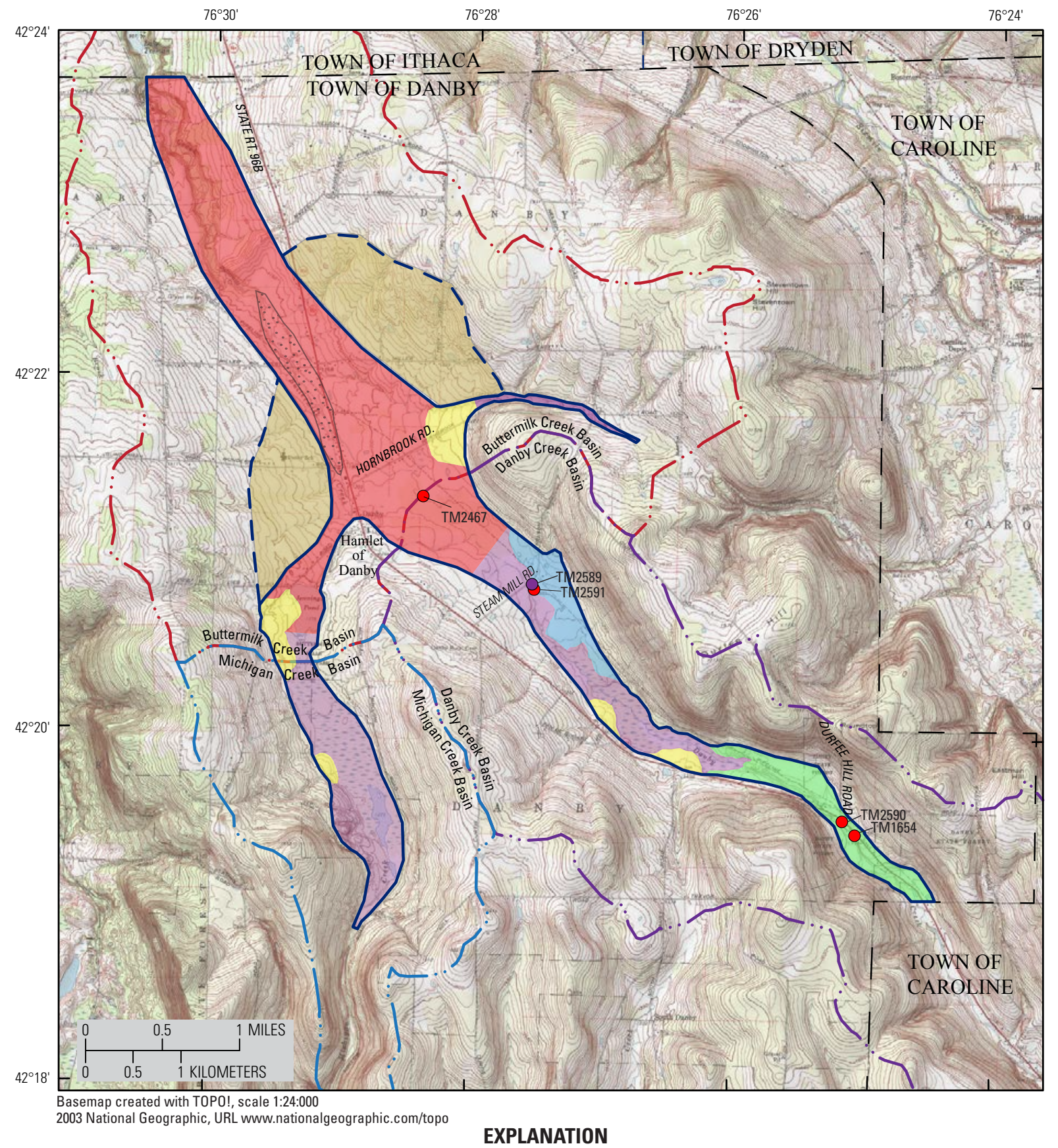

Aquifer type

Mainly confined-Stipled where aquifer is under

artesian flowing conditions, elsewhere the aquifer is under non-flowing conditions

Confined upland units-These sand and gravel deposits may be discontinuous lenses within mostly till that mantles the lower flanks of the valley walls. These units may not be hydraulically connected to the stratified-drift aquifers in the valley

Unconfined (thin) and confined

Unconfined (thin) - Alluvial fan
Aquifer type, continued

Mainly unconfined

Unknown

_ - - Aquifer boundary —Dashed lines bound areas on the sides of the valley where bedrock is overlain chiefly by till and some thin beds of sand and gravel that form local confined aquifers. It is unknown whether these local aquifers are hydraulically connected to the aquifer(s) in the valley

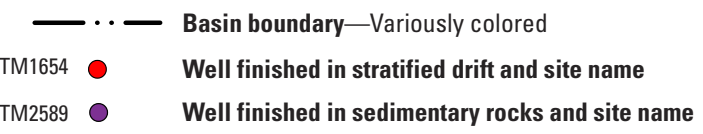

Figure 12. The types of stratified-drift aquifers in the upper Buttermilk Creek, Danby Creek, and Michigan Creek valleys in the Town of Danby, Tompkins County, New York. 
However, the yields available from bedrock wells are generally much lower than from wells finished in sand and gravel. In the uplands, bedrock is both the only dependable source of water as well as the most economical source of potable water for homes, farms, and small commercial facilities.

Generally, water-well drillers do not drill wells more than 300 to $400 \mathrm{ft}$ deep into bedrock in the study area because well yields typically decline and the water typically becomes increasingly more mineralized and less potable with increasing depth. Well yields generally decline with increasing depth because the density, width, and connectivity of water-bearing fractures decrease with increasing depth. The deepest domestic well completed in bedrock (TM2519) in the Town of Danby was $420 \mathrm{ft}$ deep (reported yield was $0.1 \mathrm{gal} / \mathrm{min}$ before hydraulic fracturing [fracking] and $1.5 \mathrm{gal} / \mathrm{min}$ after fracking).

In the southern part of Tompkins County, records from water-well drillers indicate that 2 to $5 \mathrm{gal} / \mathrm{min}$ can usually be obtained from wells that tap bedrock at most locations. Locally, yields as large as 10 to $30 \mathrm{gal} / \mathrm{min}$ or as small as less than $1 \mathrm{gal} / \mathrm{min}$ are obtained (Miller, 2009).

\section{Aquifer Geometry}

The stratified-drift aquifer system in the study area is contained in narrow, high-altitude valleys. These valleys contain relatively thin stratified- and unstratified-drift deposits. In most places in the study area, the thickness of these deposits are less than $100 \mathrm{ft}$, except in the northern part of upper Buttermilk Creek valley, where it is as much as $160 \mathrm{ft}$ thick. About two-thirds of the drift is composed of fine-grained deposits (till or glaciolacustrine fine sand, silt, and clay) that form confining units. The remaining one-third of the drift is composed of coarse-grained deposits (sand and gravel) that form the unconfined and confined aquifers.

\section{Unconfined Aquifers}

In the southern part of Danby Creek valley, an unconfined aquifer (green aquifer unit shown in fig. 12) that is 0.1 to 0.2 -mi wide extends from the kame-end moraine at the southern end of the large wetland to the southern border of the town. The aquifer is composed of kame-end moraine, outwash, and Holocene alluvium (fig. 6). The unconfined aquifer was $32 \mathrm{ft}$ thick at test-well sites TM1035 and TM2590 (well construction logs in appendix 2, fig. 2-3), Durfee Hill Road (fig. 10) and at least $41 \mathrm{ft}$ thick at domestic well TM1654 (fig. 12). This aquifer is underlain by till (fig. 10; appendix 2, fig. 2-3).

Several of the large alluvial fans that extend throughout the study area (fig. 6) may form local, discontinuous unconfined aquifers where they have a sufficient saturated thickness (fig. 12). These formations may be as thick as 25 to $35 \mathrm{ft}$ at the apex of the fan and become thinner toward the lower edges of the fans where they eventually pinch out.
Although these aquifers are small, they typically receive high rates of recharge. In addition to receiving recharge from precipitation that directly falls on the fan, these fans are also recharged from tributary streams that typically lose water as they flow over the fans.

\section{Confined Aquifers and Confining Units}

The confined aquifers in upper Buttermilk Creek valley are as much as $0.65 \mathrm{mi}$ wide in the southern part and narrow to $0.3 \mathrm{mi}$ wide in northern part of the valley (fig. 12). The upper confined aquifer (fig. 8) is south of the kame-end moraine (fig. 6) that crosses the valley in the northern part of the study area. This aquifer is typically 5 to $10 \mathrm{ft}$ thick and is 20 to $40 \mathrm{ft}$ below land surface (fig. 8). Many domestic wells in the valley in this area are completed in this aquifer. This aquifer is confined above and below by till that typically ranges in thickness from 15 to $30 \mathrm{ft}$ (fig. 8).

A basal confined aquifer is present in the upper Buttermilk Creek interstadial buried gorge in the northern part of upper Buttermilk Creek valley (fig. 7) and in the eastern part of the southern part of the valley (fig. 8). Although the basal confined aquifer was absent at several well sites in the western part of the valley, it may be present in other areas. For example, at test-well site TM2806, well depth $47 \mathrm{ft}$, (fig. 11; well log in appendix 2, fig. 2-5) a second confined aquifer (probably the basal aquifer) was penetrated at 40 to at least $47 \mathrm{ft}$. Although the well was not drilled deep enough to penetrate bedrock, the results of a passive seismic survey at the well site indicated that bedrock was about $53 \mathrm{ft}$ below land surface. The basal confined aquifer ranges in thickness from 3 to $24 \mathrm{ft}$ and lies 58 to $74 \mathrm{ft}$ below land surface in the central part of the valley, but locally it can be shallower (20 to $40 \mathrm{ft}$ below land surface) such as along the edges of the valley (fig. 8). This aquifer is confined above by 15 to $30 \mathrm{ft}$ of till in the southern part of the valley and by as much as $157 \mathrm{ft}$ of mostly till in the northern part of the valley and is confined from below by bedrock (figs. 7 and 8).

In the northern part of Danby Creek valley, underlying an unconfined aquifer, there is an upper confined aquifer in the bottom of a shallow channel that had contained a shallow proglacial lake (figs. 9 and 12). In this shallow proglacial lake, a thin layer of glaciolacustrine fine sand and clay (confining unit) was deposited on top of an undifferentiated sand and gravel deposit (fig. 9). The glaciolacustrine sediments were subsequently overlain by Holocene alluvial-fan deposits (sand and gravel), which might form a local unconfined aquifer in the eastern part of the valley (fig. 9). The confined aquifer was 7 -ft thick and was at depths from 24 to $31 \mathrm{ft}$ at nested, test-well site TM2589 and TM2591 (appendix 2, fig. 2-4), Steam Mill Road (fig. 9). Elsewhere, the extent of this aquifer is unknown. 


\section{Groundwater Recharge}

Groundwater is recharged ultimately by infiltration of precipitation (rain and snowmelt) on the land surface. The amount of recharge to an aquifer is needed to determine a groundwater budget and the long-term availability of groundwater. The distribution and amount of recharge in the study area varies spatially, seasonally, and by degree of aquifer confinement. Most recharge is during the plant dormant season, typically March through April; and mid-October through mid-December. During this period, groundwater levels generally rise in the aquifers (fig. 13), indicating that aquifer storage is increasing. During the growing season (May through mid-October), evapotranspiration (the process by which water is changed from the liquid state into the vapor state and transpiration is the process by which water vapor escapes from living plants into the atmosphere) typically exceeds precipitation, which results in decreasing water levels and indicates that aquifer storage is decreasing. However, during large storms, the rate of recharge can exceed the rate of evapotranspiration, which results in a rise of groundwater levels even during the growing season (fig. 13).

The sources of recharge can be more easily estimated for unconfined aquifers than for confined aquifers. Large amounts of recharge are readily available to unconfined aquifers because these aquifers are exposed at land surface. Water from various sources, such as direct precipitation or loss from tributary streams contributes most of the recharge to unconfined aquifers. Recharge to confined aquifers is limited and generally poorly known because these aquifers are buried and typically only a small part of the aquifer is open to the atmosphere that can be recharged from direct precipitation. In the parts of the study area that contain confined aquifers, the extent, thickness, and type of sediments that overlie the aquifers affect the flux of water from the surface to the aquifers. The sources of recharge to and the discharge from the aquifers are depicted in figure 14 .

\section{Unconfined Aquifer}

The principal sources of recharge to the unconfined aquifers in the study area include direct infiltration of precipitation (rain and snowmelt) at land surface, unchanneled surface runoff from adjacent hillsides that seeps into the aquifer along the edges of the valley, groundwater inflow from till and bedrock that enters the aquifer along the sides of the valley, seepage loss from upland-tributary streams where they flow over alluvial fans in the valley, and upward leakage from the underlying geologic units in the valley where the hydraulic head in these units are higher than the water table in the unconfined aquifer.

Direct infiltration of precipitation seeps to the water table and recharges the unconfined aquifer where sand and gravel is at land surface and when this water is not lost to evapotranspiration (the sum of evaporation and transpiration). The mean annual precipitation in the study area is about
36.7 inches per year (in/yr) or 3.1 feet per year (ft/yr), based on precipitation data for 1971-2000 for Ithaca, N.Y. (Northeast Regional Climate Center, 2012), which is $5.0 \mathrm{mi}$ northeast of the study area (fig. 4). In the southern part of Tompkins County, the mean annual evapotranspiration is estimated to be $18.5 \mathrm{in} / \mathrm{yr}$ (1.5 ft/yr; Kontis and others, 2004, plate 1). The amount of annual recharge from precipitation that falls directly over the unconfined aquifer in Danby Creek valley at the southern part of the study area can be estimated using equation 1 :

$$
R_{p}=(P-E T) A
$$

where

$$
\begin{array}{ll}
R_{p} & \begin{array}{l}
\text { is annual recharge from } \\
\text { precipitation that falls directly over } \\
\text { the aquifer, in cubic feet per year, }
\end{array} \\
P & \begin{array}{l}
\text { is mean annual precipitation, in feet } \\
\text { per year, }
\end{array} \\
E T \quad \begin{array}{l}
\text { is mean annual evapotranspiration, } \\
\text { in feet per year, and } \\
\text { is area of the top of the unconfined } \\
\text { aquifer, in square feet. }
\end{array}
\end{array}
$$

Using equation 1 , the estimated annual recharge $(R p)$ from precipitation that falls directly over the unconfined aquifer in Danby Creek valley (the area represented by the contiguous surficial geologic deposits kame moraine, outwash sand and gravel, and alluvial fan deposits in fig. 6; and shown as a green unconfined aquifer unit in fig. 12) is computed to be $1.25 \times 10^{7}$ cubic feet per year $\left(\mathrm{ft}^{3} / \mathrm{yr}\right)$ or 93.5 million gallons per year (Mgal/yr), where $P$ is equal to 3.1 feet per year (ft/yr), $E T=1.5$ feet per year (ft/yr), and $A=7.81 \times 10^{6}$ cubic feet $\mathrm{ft}^{3}$ (0.28 square mile).

Another source of recharge to the unconfined aquifer is from adjacent unchanneled surface runoff and groundwater inflow that seeps into the aquifer from adjacent hillsides along the edges of the valleys (figs. 14 and 15). Runoff and groundwater inflow from these hillsides infiltrate into the unconfined aquifer along the edges of the valley (fig. $14 B$ and $14 C$ ). The annual amount of recharge from these unchanneled hillsides can be estimated by using equation 2 :

$$
R_{u}=(P-E T) A,
$$

where

$$
\begin{array}{ll}
R_{u} \quad \begin{array}{l}
\text { is annual recharge from } \\
\text { unchanneled hillsides, in cubic feet } \\
\text { per year, }
\end{array} \\
P \quad & \begin{array}{l}
\text { is mean annual precipitation, in feet } \\
\text { per year, }
\end{array} \\
E T \quad & \begin{array}{l}
\text { is mean annual evapotranspiration, } \\
\text { in feet per year, and }
\end{array} \\
\text { is area of unchanneled hillsides that } \\
\text { are adjacent to the unconfined } \\
\text { aquifer, in square feet. }
\end{array}
$$




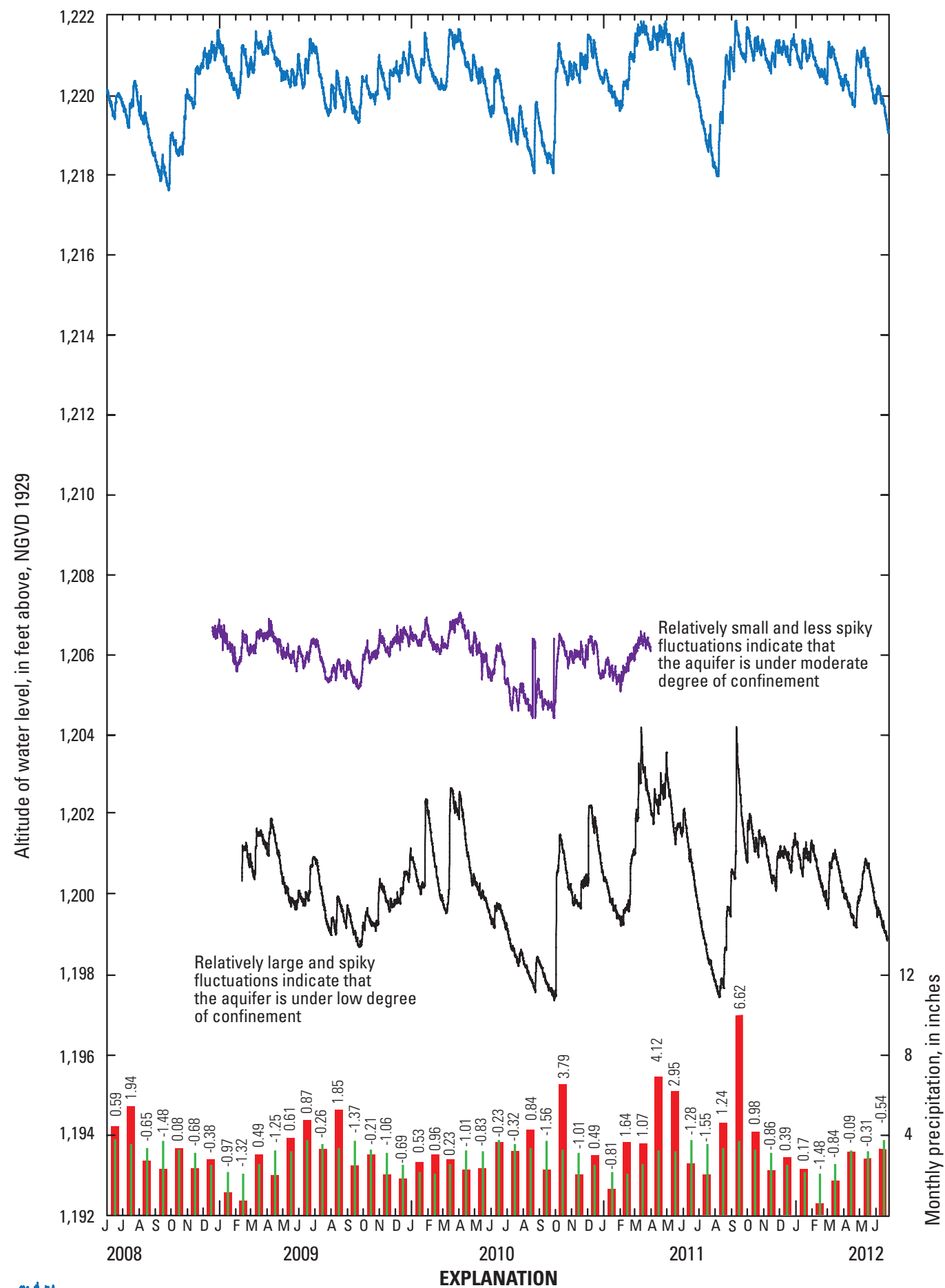

Potentiometric surface-Shows altitude (in feet) of the water level in well TM2467. Datum is NGVD 29

Potentiometric surface-Shows altitude (in feet) of the water level in well TM2588. Datum is NGVD 29

Potentiometric surface-Shows altitude (in feet) of the water level in well TM2591. Datum is NGVD 29

$\stackrel{\infty}{\infty}$ 品 Monthly precipitation at the National Oceanic and Atmospheric Administration weather station at Cornell University, Ithaca, NY-Red bar shows monthly amount of precipitation (in inches). Green line shows monthly normal precipitation and number is the departure, in inches, of actual precipitation from the monthly normal precipitation. http://www.ncdc.noaa.gov/

Figure 13. Altitude of groundwater levels in test wells TM2467, (near Town of Danby Highway Department) from June 1, 2008, to June 26, 2012, TM2588 (near the Hamlet of Danby) from December 17, 2008, to March 30, 2011, and TM2591, (Steam Mill Road) from February 11, 2009, to June 26, 2012, Town of Danby, New York. 
A. Northern part of study area-Isolated basal confined aquifer

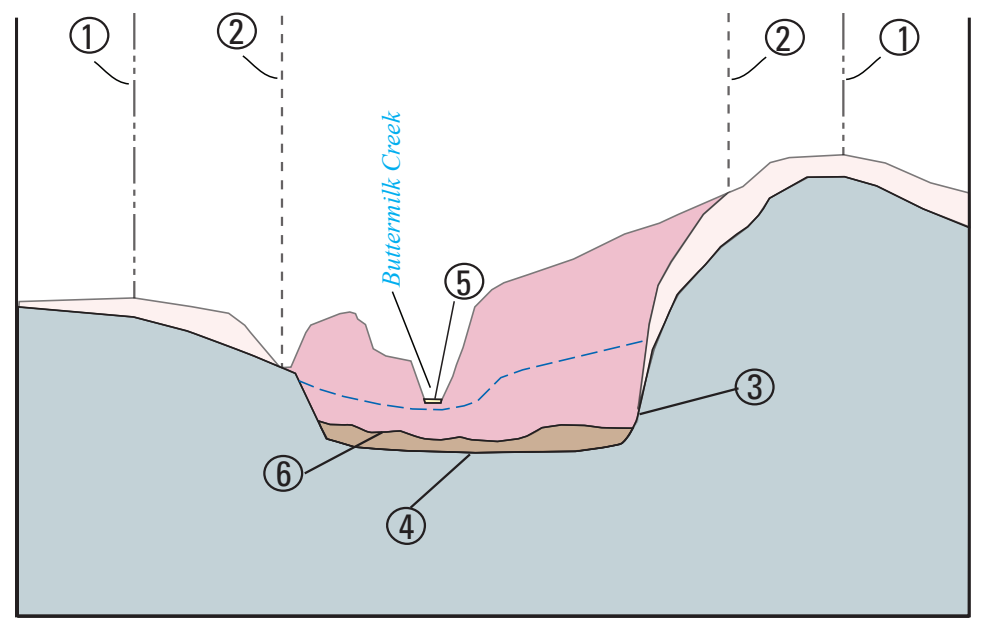

\section{B. Central part of study area-Unconfined and confined aquifers}

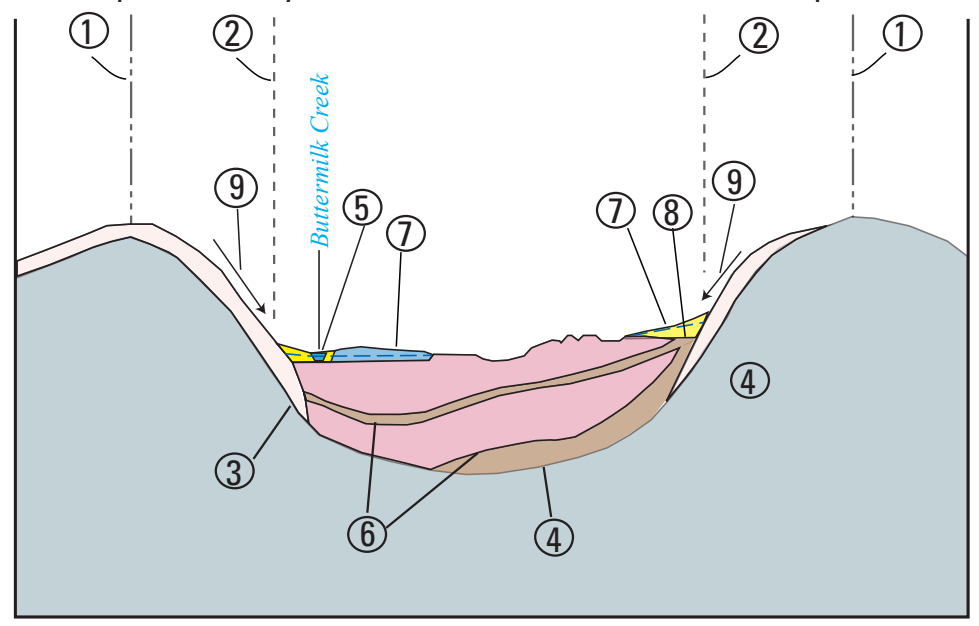

C. Southern part of study area-Unconfined aquifer

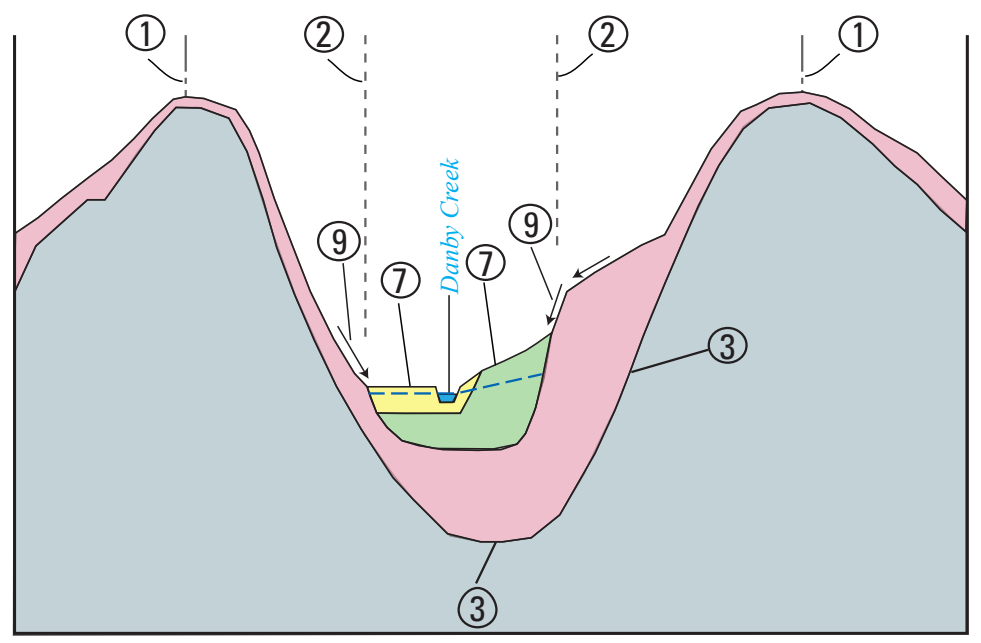

\section{EXPLANATION}

\section{Hydrologic and recharge components}

(1) Drainage divide: a boundary between adjacent drainage basins. Ground water and surface water divides in uplands are generally coincident

(2) Edge of valley-fill deposits

(3) Lateral contact between bedrock and either finegrained stratified drift and till. Flow across the contact is small

(4) Some water may recharge the buried aquifer as subsurface flow from underlying till or bedrock. Flow across the contact is small

(5) Little or no water recharges the buried aquifer from streams flowing across the fine-grained deposits in the main valley. The main stem stream in the valley is typically a discharge zone (gains water)

(6) Some water may recharge the confined aquifer as subsurface flow from adjacent fine-grained sediments, especially when the aquifer is pumped

(7) Precipitation recharges permeable surficial alluvial fans, kame moraines, outwash, and deltaic deposits, some of which constitute unconfined aquifers but some may be too thin to be of practical value

(8) Precipitation recharges the confined aquifer where it crops out at land surface or underlies an alluvial fan along the edges of the valley

(9) Unchanneled and channeled runoff; and some subsurface flow from upland areas recharge surficial sand and gravel deposits along the edges of the valley and where tributary streams cross their alluvial fans. These flows may also be a source of recharge to buried aquifers (as well as precipitaion, see number 3) where confined sand and gravel units in central parts of the valley extend to the valley walls where confining units are absent and are directly overlain by surficial sand and gravel

\section{Geohydrologic units}

Water

Alluvial fan or channel sand and gravel

Deltaic pebbly sand and gravel with some silt

Outwash sand and gravel

Confined sand and gravel aquifer

Mostly till that is interlayered with some lacustrine fine sand, silt and clay

Till

Shale and siltstone

\section{Water table (unconfined aquifer)}

Figure 14. Schematic geohydrologic sections showing sources of recharge to aquifers in the $A$, northern part of the study area (upper Buttermilk Creek valley); $B$, central part of the study area (upper Buttermilk Creek valley); and $C$, southern part of the study area (Danby Creek valley), Tompkins County, New York. 
Geohydrology and Water Quality, Stratified-Drift Aquifers, Upper Buttermilk Creek and Danby Creek Valleys, N.Y.

Using equation 2 , the estimated annual recharge $(R u)$ to the unconfined aquifers in Danby Creek valley from precipitation that falls on adjacent unchanneled hillsides is estimated to be $4.46 \times 10^{7} \mathrm{ft}^{3} / \mathrm{yr}(334 \mathrm{Mgal} / \mathrm{yr})$, where $P=3.1 \mathrm{ft} / \mathrm{yr}, E T=1.5 \mathrm{ft} / \mathrm{yr}$, and $A=2.79 \times 107 \mathrm{ft}^{2}\left(1.00 \mathrm{mi}^{2}\right)$. Because the Danby Creek valley is narrow and the areas of the adjacent unchanneled hillsides are much larger (3.4 times larger) than the valley floor: the unconfined aquifer receives proportionally 3.4 times more recharge from the hillsides (334 Mgal/yr) than from precipitation that falls directly over the aquifer ( $93.5 \mathrm{Mgal} / \mathrm{yr})$.

Additional sources of recharge to the unconfined aquifer in Danby Creek valley are tributaries that drain channelized upland basins (fig. 15). As upland tributary streams enter larger valleys floored with permeable sand and gravel, they typically loose water by infiltration through the streambed (Randall, 1978). These streams typically lose water where they flow over the alluvial fans in the large valleys. However, recharge from these tributary streams is difficult to estimate because streambed leakances are generally poorly known (Kontis and others, 2004). Paired streamflow measurements at the upstream (contact of the stratified drift and till-mantled bedrock valley wall) and downstream (mouth of stream) reaches can yield a rate of loss for that reach at that time and flow condition. However, paired streamflow measurements were not conducted for this study because most measuring sites were inaccessible. In addition to the unconfined aquifer in the southern part of Danby Creek valley, upland tributaries that flow over their isolated alluvial fans in the northern part of Danby Creek valley also provide recharge to these small unconfined aquifers. However, these small isolated alluvial fans may not be reliable aquifers because generally the deposits are thin; thus, the saturated thickness is thin and may be unsaturated during dry periods.

In the southern part of the study area, the recharge from six upland tributaries (losing streams) that flow over the contiguous unconfined aquifer in the Danby Creek valley (the green unconfined aquifer unit in fig. 15) was estimated using the following steps:

1. Flow-duration at 10-percent intervals was computed for the six upland tributaries that flow over alluvial fans on the contiguous unconfined aquifer. These flow-duration intervals were computed by using the 1931-60 flowduration curve developed for Sage Brook near South New Berlin, N.Y. (streamgage 01501500) by Ku and others (1975). Sage Brook drains a small upland basin $\left(0.61 \mathrm{mi}^{2}\right)$ that is composed mostly of till over bedrock, which is similar to the upland drainage basins in this study area.

2. The mean runoff (in cubic feet per square mile) was used from the Sage Brook flow-duration curve for each 10-percent flow-duration interval.

3. The upland drainage areas of the six upland tributaries that lose water to the contiguous unconfined aquifer in
Danby Creek valley were computed using a geographic information system (GIS).

4. The mean runoff values from step 2 were multiplied by the areas of the six upland drainage basins (fig. 15) from step 3 to obtain runoff (in $\mathrm{ft}^{3} / \mathrm{s}$ ) in each stream in Danby Creek valley for each 10-percent flow-duration interval.

5. The length of each tributary channel that crosses the aquifer in Danby Creek valley was measured (in $\mathrm{ft}$ ). These channel lengths were multiplied by $1.0 \mathrm{ft}^{3} / \mathrm{s}$ per $1,000 \mathrm{ft}$ to determine the upper limit of the rate of loss of flow that was most likely lost during high-flow periods. For tributary streams in the Susquehanna River Basin, Randall (1978) determined that a rate of loss of $1.0 \mathrm{ft}^{3} / \mathrm{s}$ per 1,000 ft of channel was the typical maximum amount of loss for periods when streamflow is available.

6. For each tributary channel, the recharge for each 10-percent flow-duration interval were computed using the following criteria: For flow-duration intervals when the rate of flows that were determined in step 5 exceeded those in step 4, the flow in step 4 were used (which assumes 100 percent of streamflow infiltrates into the unconfined aquifer). For intervals where flows in step 4 exceeded those in step 5, the flows in step 5 were used (which assumes infiltration is a fraction of streamflow).

7. To determine the total recharge from each tributary, the results of step 6 were summed. The results of the above calculations indicated that the total drainage area of the six upland basins is $0.58 \mathrm{mi}^{2}$ and the sum of all recharge from losing streams that cross the unconfined aquifer was $0.75 \mathrm{ft}^{3} / \mathrm{s}$ (table 2).

Some groundwater in the unconfined aquifer in Danby Creek valley is also recharged from bedrock. Some groundwater moves upward from the underlying bedrock at the bottom of the valley to the stratified-drift aquifer in the valley as indicated by the upward vertical gradient determined at the test wells TM1035 and TM2590 (fig. 11, well logs shown in appendix 2, fig. 2-3) in the southern part of the study area. For example, on November 5, 2008, the hydraulic head in test well TM1035 (finished in bedrock) was $6.4 \mathrm{ft}$ higher than the water level in test well TM2590 (finished in the unconfined aquifer; appendix 2, fig. 2-3). However, the groundwater flow is small when compared to the horizontal flow in the unconfined aquifer because the bedrock is fairly impermeable (typically having a hydraulic conductivity less than 1 foot per day, $\mathrm{ft} / \mathrm{d}$ ) as well as is the till that overlies bedrock.

The estimated average-annual amounts of recharge to the unconfined aquifer in Danby Creek valley are summarized in table 2. The percentages of all sources of recharge to the contiguous unconfined aquifer in Danby Creek valley include 16 percent from precipitation that falls directly over the aquifer, 55 percent from runoff and groundwater inflow from adjacent unchanneled hillsides, and 29 percent 


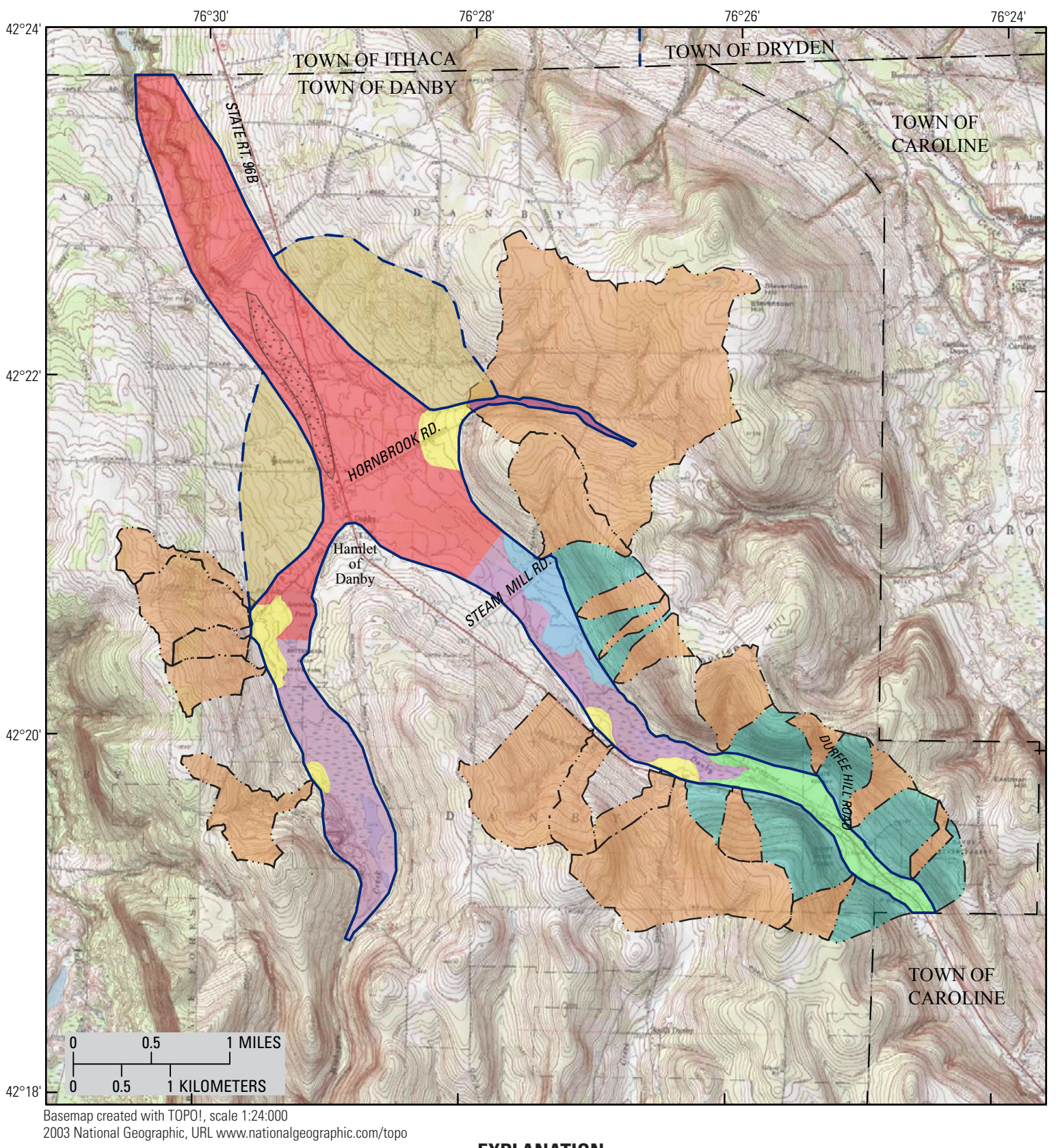

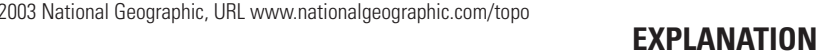

Unchannelized upland drainage basin-Adjacent smooth hillsides where runoff and groundwater inflow from till and bedrock recharge the unconfined aquifer in Danby Creek Valley

Channelized upland drainage basin-Contains a stream that gains water in the uplands and is likely to lose water where it flows on sand and gravel deposts in the valley

\section{Aquifer type}

Mainly confined-Stipled where aquifer is under artesian flowing conditions, elsewhere the aquifer is under non-flowing conditions

Confined upland units-These sand and gravel deposits may be discontinuous lenses within mostly till that mantles the lower flanks of the valley walls. These

Aquifer type, continued

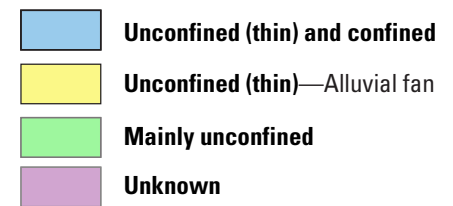

- Aquifer boundary-Dashed lines bound areas on the sides of the valley where bedrock is overlain chiefly by till and some thin beds of sand and gravel that form local confined aquifers. It is unknown whether these local aquifers are hydraulically units may not be hydraulically connected to the stratified-drift aquifers in the valley

connected to the aquifer(s) in the valley

Figure 15. Channeled and unchanneled upland drainage basins that provide recharge to the unconfined aquifers in the upper Buttermilk Creek, Danby Creek, and Michigan Creek valleys in the Town of Danby, Tompkins County, New York. 
Table 2. Estimated average annual recharge to the contiguous unconfined aquifer in Danby Creek valley, Town of Danby, New York. [ $\mathrm{ft}^{3} / \mathrm{s}$, cubic feet per second; $\mathrm{ft}^{3} / \mathrm{d}$, cubic feet per day; $\mathrm{ft}^{3} / \mathrm{yr}$, cubic feet per year; Mgal $/ \mathrm{d}$, million gallons per day; and Mgal $/ \mathrm{yr}$, million gallons per year]

\begin{tabular}{|c|c|c|c|c|c|c|}
\hline Sources of recharge & $\left(\mathrm{ft}^{3} / \mathrm{s}\right)$ & $\left(\mathrm{ft}^{3} / \mathrm{d}\right)$ & $\left(\mathrm{ft}^{3} / \mathrm{yr}\right)$ & (Mgal/d) & (Mgal/yr) & Percent of total \\
\hline $\begin{array}{l}\text { Precipitation that falls directly on entire extent of } \\
\text { aquifer }\end{array}$ & 0.40 & 34,236 & $12,496,000$ & 0.26 & 93 & 16 \\
\hline \multicolumn{7}{|c|}{ Upland sources } \\
\hline $\begin{array}{l}\text { Runoff and groundwater inflow from adjacent } \\
\text { unchannelized hillsides }\end{array}$ & 1.41 & 122,300 & $44,640,000$ & 0.91 & 334 & 55 \\
\hline $\begin{array}{l}\text { Seepage from losing upland tributaries that flows over } \\
\text { the aquifer (channeled flow) }\end{array}$ & 0.75 & 64,800 & $23,652,000$ & 0.48 & 177 & 29 \\
\hline Total average annual recharge to aquifer & 2.56 & 221,336 & $80,788,000$ & 1.65 & 604 & 100 \\
\hline
\end{tabular}

from losing streams that cross the aquifer (table 2). The total annual recharge to the contiguous unconfined aquifer is $2.56 \mathrm{ft}^{3} / \mathrm{s}$ (604 Mgal/yr)(table 2). The relatively small portion of recharge that comes from precipitation that falls directly on the aquifer in Danby Creek valley is a result of the relatively narrow valley (typically 600 to $1,000 \mathrm{ft}$ wide), and thus, a relatively small part of the total drainage area. Hence, a proportionally larger amount of precipitation falls in the uplands in Danby Creek valley than in wider valleys. In general, where the unconfined aquifer in a valley is wider, more recharge is derived from precipitation as it falls directly on the aquifer when compared to that from other upland sources of recharge. For example, in two other central New York valleys in which recharge was estimated, Meads Creek valley is moderately wide (1,500 to 3,000 ft) and Otter Creek/Dry Creek valley is wide $(6,000$ to $8,000 \mathrm{ft}$; valleys not shown in this report); the portions of recharge that were derived from precipitation that falls directly on these aquifer valleys constituted 28 and 38 percent, respectively (Miller and others, 2008; and Miller and others, 1998), of the total recharge to these aquifers (compared to 16 percent in this study area).

\section{Confined Aquifers}

The buried aquifers in the study area are confined by relatively impermeable fine-grained unconsolidated sediments (till or glaciolacustrine fine sand, silt, and clay) that impede or slow infiltration of water (recharge) from surface sources to the aquifer. However, parts of some confined aquifers appear to be semiconfined where they are bounded by relatively lowto-moderate permeable sediments (glaciolacustrine fine sand). In the part of the study area that contains confined aquifers (fig. 12), the sources and amounts of recharge are difficult to identify because the aquifers are concealed from view at land surface by overlying deposits (recent alluvium and confining units) and, in most areas, there is insufficient subsurface data (such as, well records, water-level measurements, and geophysical data). Therefore, the amount of recharge to the confined aquifers was not estimated in this study. In addition to more groundwater data, a numerical groundwater flow model would be the best tool to estimate the amount of water that recharges the confined aquifers. However, construction of a numerical groundwater flow model was beyond the scope of this study.

Although there were insufficient data to quantify the amount of recharge to the confined aquifers, some data are available to conceptualize how and where confined aquifers are recharged. Potential sources of recharge can be inferred by examining trends of groundwater levels. The trend of groundwater levels can offer clues to the degree of confinement of the aquifers.

In this study area, groundwater levels were monitored continuously for 2 to 3 years in test wells TM2467, TM2588, and TM2591, (fig. 13, location of wells shown in fig. 11). The degree of confinement is indicated by the response (or lack thereof) in water levels to phenomena, such as relatively rapid increases in water levels (spikes) during and just following individual rain-storm events, and from fluctuations caused by changes in stream and lake stages (Heath, 1976). Aquifers of low-to-moderate confinement have confining units that are discontinuous ("windows" of highly permeable sediments in the confining layer), thin, or consist of leaky semipermeable sediments such as fine-grained sand. Aquifers of low-to-moderate confinement receive moderate amounts of recharge from one or more of the following sources of water: (1) precipitation that falls directly on the windows of permeable sediments within the confining unit (the confining unit is discontinuous), (2) precipitation that falls directly on semipermeable parts of the confining unit and slowly infiltrates downward to the confined aquifer, and (3) groundwater inflow from till and bedrock from adjacent hillsides that seeps into the aquifer along the edges of the valley. Hydrographs of wells finished in aquifers of low-to-moderate degree of confinement are spiky and display relatively large fluctuations during the storm events, as determined for TM2591 (fig. 13).

Aquifers with a high degree of confinement (highly confined aquifers): (1) are distal from land-surface sources of recharge, (2) are confined by thick, extensive sediments with low hydraulic conductivities (low permeability), such as 
till, silt, clay and shale, (3) receive only minor leakage from confining units, and (4) are insensitive to fluctuation in water levels in response to precipitation events. For highly confined aquifers, hydraulic conductivities are at least two orders of magnitude less than that of the aquifer. Groundwater level fluctuations in aquifers under high degree of confinement show gradual seasonal changes but show little or no changes due to individual storms (spikes). Wells TM1008 and TM1009 (well depths 187 and $130 \mathrm{ft}$, respectively) in lower Sixmile Creek valley, 4 mi east of Danby (locations shown in fig. 11), are examples of wells that are finished in confined aquifers (Miller and Karig, 2010, appendix 1) under a high degree of confinement (fig. 16).

The groundwater levels in test wells TM2467, TM2588, and TM2591 in this study area show that the degrees of confinement vary from low-to-moderate depending on location (fig. 13). Fluctuation of groundwater levels in response to storms is readily apparent (hydrograph with spikes and relatively large fluctuations during storm events) in well TM2591, somewhat less apparent in well TM2467, and least apparent in well TM2588 (fig. 13). The largest groundwater fluctuations were in well TM2591 (at the headwaters of Danby Creek valley, fig. 13), which suggests that the thin confining unit in that area (a 9-ft layer of fine sand and clay with some silt; fig. 9 and well-construction log in appendix 2, fig. 2-4) may be a discontinuous lens rather than an extensive layer. Also, the well site is on a large alluvial fan on the east side of Danby Creek valley (fig. 5, 6 and 12) - alluvial fans are areas where confined aquifers are commonly recharged (fig. 14B). In either case, the relatively large fluctuation in groundwater levels in response to storms indicates that the confined aquifer is receiving relatively large amounts of recharge from a nearby source.

Groundwater fluctuations were smaller in well TM2467 (at the groundwater divide near Hornbrook Road) than in well TM2591 (fig. 13), which suggests that there is more confinement in the area of well TM2467 than in the area of well TM2591. The confining layer is relatively thick ( $35 \mathrm{ft})$ at well TM2467 (fig. 8 and appendix 2, fig. 2-2), and, thus, is likely to be more extensive than the confining layer near TM2591. However, the moderate spikes and fluctuations shown in this hydrograph for well TM2467 indicates that there is substantial hydraulic connection to a nearby source of recharge, even though the well is more distal to plausible sources of recharge than is well TM2591. The most likely source of nearby recharge to well TM2467 is the large alluvial fan $0.5 \mathrm{mi}$ to the northeast on the east side of the valley near Hornbrook Road (figs. 6 and 8), which is where the basal confined aquifer in figure 8 is shown rising in altitude and meeting the unconconfined aquifer at the alluvial fan.

The abruptness in the spikes in the water level and the magnitude in the rise in the groundwater level were the least in well TM2588 (fig. 13, location shown in fig. 11) near the Hamlet of Danby in the western part of the headwaters of upper Buttermilk Creek valley. These two characteristics of the hydrograph indicate that the aquifer near well TM2588 is more confined and more distal from sources of recharge than aquifers near wells TM2591 and TM2467. The subtle spikes shown in the hydrograph for well TM2588 coincide with individual storms and also indicate that, although the aquifer is under a higher degree of confinement at this site than at the sites of wells TM2591 and TM2467 in this study

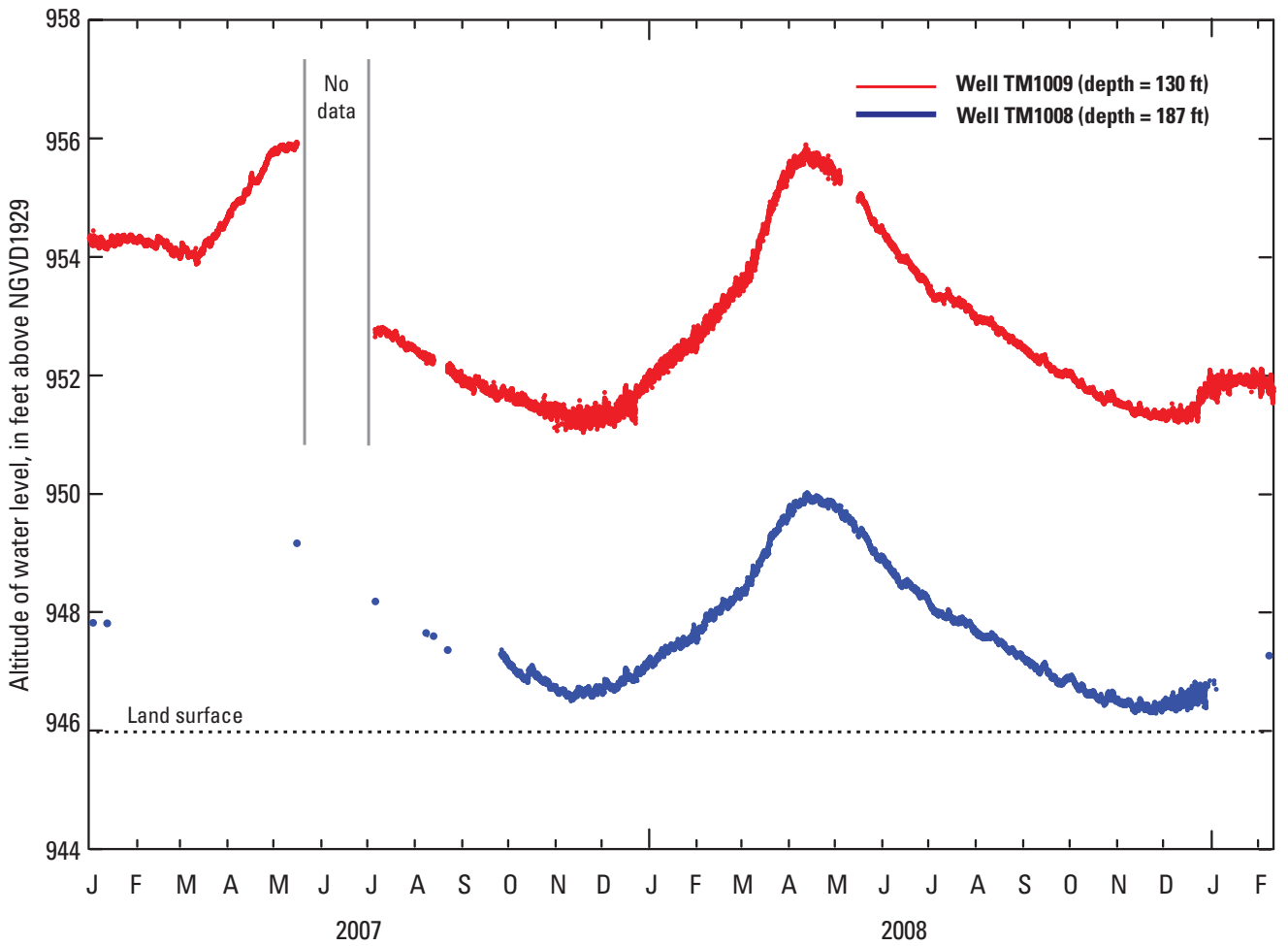

Figure 16. Altitude of groundwater levels in wells TM1008 and TM1009 finished in aquifers under high degree of confinement, lower Sixmile Creek valley, Town of Caroline, Tompkins County, New York. (Location of wells shown in fig. 11.) 
area, the aquifer is not as confined as those aquifers that wells TM1008 and TM1009 are finished in the lower Sixmile Creek valley (fig. 16).

\section{Groundwater Flowpaths and Discharge}

In the Danby Creek valley (southern part of the study area), groundwater in the unconfined aquifers flows to surface-water bodies (streams and wetlands) (fig. 17). The groundwater discharges (1) to domestic, commercial, and farm wells, (2) to Danby Creek, (3) to a large wetland in the central part of Danby Creek valley, and (4) as losses because of evapotranspiration (fig. 17). Where the unconfined aquifer is less than $15 \mathrm{ft}$ from land surface, transpiration during the growing season reduces the amount of water that infiltrates to the water table and evaporation removes some water from the top of the water table. Mean annual evapotranspiration is estimated to range between 19 and $20 \mathrm{in} / \mathrm{yr}$ or about one-half of the annual precipitation in this area (Kontis and others, 2004; plate 1).

In the upper Buttermilk Creek valley, groundwater in the confined aquifers generally flows northwestward (downvalley) and discharges to (1) domestic and commercial wells, (2) Buttermilk Creek in the area near the northern town border, and (3) a small unnamed stream in a ravine at the south end of Buttermilk State Park just north of the town border (fig. 17). In the area of artesian-flowing conditions in the southwest part of the valley (shown by stippled area in fig. 17), the wells typically are not capped and continuously flow.

Although groundwater discharges continually throughout the year, the rate of discharge is typically less than recharge from late fall to mid spring. During this period, the rate of discharge is less than recharge because plants are dormant and the temperature is cool, which result in less loss as evapotranspiration and, therefore more precipitation is available as recharge. The greater rate of recharge is reflected by rising groundwater levels in the aquifer (fig. 13) indicating that aquifer storage is increasing. Conversely, during the growing season (from late spring to mid fall), the rate of discharge is generally greater than the rate of recharge and is reflected by groundwater levels that typically decrease in the aquifers during this period (fig. 13) indicating that aquifer storage is decreasing.

\section{Groundwater Withdrawals}

An estimated 301 people depend on groundwater from the upper Buttermilk Creek and Danby Creek stratifieddrift aquifer system (table 3). The estimate was determined by a visual count of homes, farms, and businesses over the aquifer area on orthoimage maps (minus the number of households that were dependent on wells that tap bedrock) and multiplying that result by 2.3 , the average number of persons per households in Tompkins County (table 3) from 2010 U.S. Census (U.S. Census Bureau, 2012). Because no people live over the Michigan Hollow Creek valley part of the aquifer system, no groundwater is withdrawn from wells. Another estimated 78 people reside in both valleys but depend on groundwater from wells that tap the bedrock (shale) aquifer (table 3).

The estimated total groundwater use from the stratifieddrift aquifer system is about 22,600 gallons per day (gal/d; 8.2 Mgal/yr) and about 5,860 gal/d (2.1 Mgal/yr) from the bedrock aquifers, based on an estimated average water use of $75 \mathrm{gal} / \mathrm{d}$ per person for self-supplied water systems in New York (Hutson and others, 2000) times the estimated 301 people that withdraw groundwater from the stratified-drift aquifers and the estimated 78 people that withdraw groundwater from the bedrock aquifers (table 3).

\section{Potential for Large-Capacity Municipal or Commercial Wells}

The potential for large ground-water withdrawals is of interest to town and county planners as well as to potential commercial businesses that may wish to locate in the area. In addition, should hydraulic fracturing for unconventional development of wells drilled for natural gas be allowed in New York, the gas drilling companies may be seeking to withdraw large amounts of water from aquifers as well as surface water. The amount of recharge to stratified-drift aquifers is a key determinant of the long-term availability of water. In general, more recharge water is available to unconfined sand and gravel aquifers than to confined aquifers. Although several other large through valleys studied by the USGS contain stratified-drift aquifers capable of large yields (Miller, 2009; Miller and Karig, 2010; Miller and Bugliosi, 2013), the aquifers in this study area might not yield water in large quantities. Low yields of water are expected in this study area because the main confined aquifers in upper Buttermilk valley are thin and the main unconfined aquifer in Danby Creek valley is relatively small in areal extent and is thinly saturated (fig. 12).

At the time of this study (2006-12), all wells in the upper Buttermilk Creek and Danby Creek valleys were pumped intermittently at rates that typically range from 3 to 10 gallons per minute (gal/min) to adequately supply individual homes, small shops, or public buildings. The aquifers in these valleys could easily accommodate additional similar withdrawals. The question may arise in the future as to whether the aquifers could meet the water needs of a municipality or commercial facility which may need water in excess of $100 \mathrm{gal} / \mathrm{min}$. To meet this large demand of water, it may be feasible to use an array of wells to tap the unconfined aquifer in lower Danby Creek valley.

\section{Unconfined Aquifer in Lower Danby Creek Valley}

The lower (southeastern most) 8,000 ft of Danby Creek valley within the Town of Danby is occupied by a contiguous 


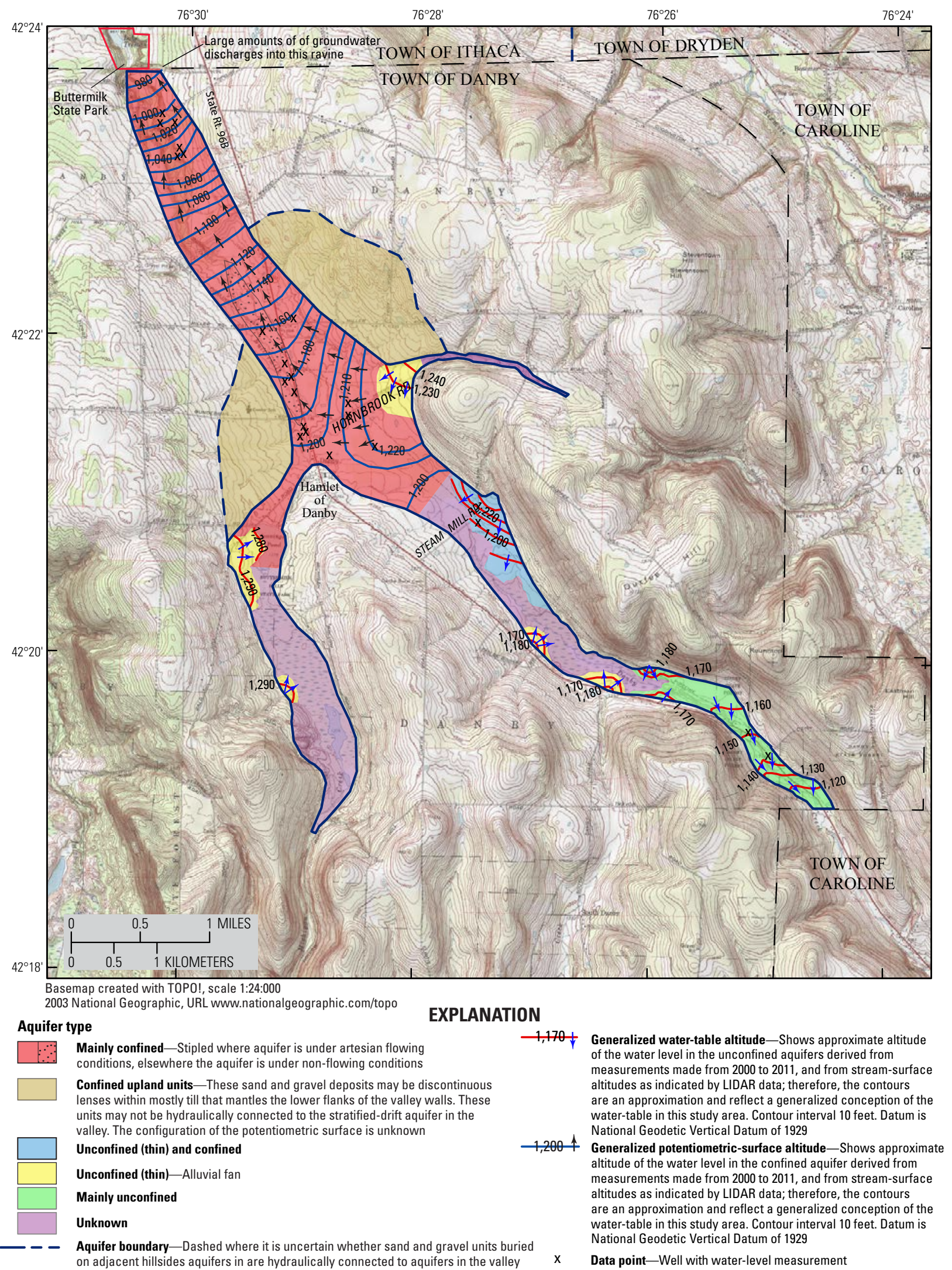

Figure 17. Water table in unconfined aquifers and the potentiometric surface in the confined aquifer in the upper Buttermilk Creek, Danby Creek, and Michigan Creek valleys in the Town of Danby, Tompkins County, New York. 
Table 3. Estimated groundwater withdrawals by users that reside over the upper Buttermilk Creek and Danby Creek valleys aquifersystem study area, 2012.

$[--$, not applicable $]$

\begin{tabular}{|c|c|c|c|c|c|c|c|c|}
\hline Users & $\begin{array}{l}\text { Estimated } \\
\text { number of } \\
\text { wells that } \\
\text { tap the } \\
\text { stratified } \\
\text { drift, sand } \\
\text { and gravel } \\
\text { aquifersa }\end{array}$ & $\begin{array}{c}\text { Estimated } \\
\text { number of } \\
\text { wells that } \\
\text { tap the } \\
\text { bedrock } \\
\text { aquifers }\end{array}$ & $\begin{array}{c}\text { Average } \\
\text { people per } \\
\text { household }\end{array}$ & $\begin{array}{l}\text { Estimated } \\
\text { number of } \\
\text { people using } \\
\text { water from } \\
\text { stratified } \\
\text { drift, sand } \\
\text { and gravel } \\
\text { aquifers }\end{array}$ & $\begin{array}{l}\text { Estmated } \\
\text { number of } \\
\text { people using } \\
\text { water from } \\
\text { bedrock } \\
\text { aquifers }\end{array}$ & $\begin{array}{l}\text { Average } \\
\text { use per } \\
\text { person, in } \\
\text { gallons } \\
\text { per day }^{d}\end{array}$ & $\begin{array}{l}\text { Estimated } \\
\text { withdrawal, } \\
\text { in gallons } \\
\text { per day from } \\
\text { stratified } \\
\text { drift, sand } \\
\text { and gravel } \\
\text { aquifers }\end{array}$ & $\begin{array}{l}\text { Estimated } \\
\text { withdrawal, } \\
\text { in gallons } \\
\text { per day from } \\
\text { bedrock } \\
\text { aquifers }\end{array}$ \\
\hline $\begin{array}{l}\text { Private homes over } \\
\text { the stratified-drift } \\
\text { aquifers in upper } \\
\text { Buttermilk Creek } \\
\text { valley }\end{array}$ & 117 & 26 & 2.3 & 269 & 60 & 75 & 20,183 & 4,485 \\
\hline $\begin{array}{l}\text { Private homes over } \\
\text { the stratified- } \\
\text { drift aquifers in } \\
\text { Danby Creek } \\
\text { valley }\end{array}$ & 14 & 8 & 2.3 & 32 & 18 & 75 & 2,415 & 1,380 \\
\hline Total & 131 & 34 & -- & 301 & 78 & -- & 22,598 & 5,865 \\
\hline
\end{tabular}

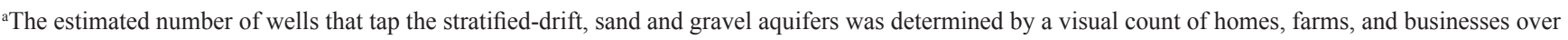
the aquifer area on orthoimage maps. Then the number of wells within the aquifer area that are known to tap bedrock were subtracted from the total number of wells.

${ }^{\mathrm{b}}$ The estimated number of wells that tap the bedrock aquifers within the area that is overlain by the sand and gravel aquifers were estimated from well records. Since well records are not available for all wells within the area that is overlain by the sand and gravel aquifers, the number of bedrock wells may be somewhat higher than indicated.

'Source: U.S. Census Bureau, 2012, http://www.census.gov/prod/cen2010/, accessed August 15, 2015.

${ }^{\mathrm{d}}$ From Hutson and others (2000).

unconfined surficial aquifer composed chiefly of sand and gravel (kames, outwash, and alluvium; fig. 6). The aquifer is relatively narrow - averaging in width of about $800 \mathrm{ft}$ and has a small saturated thickness of about $20 \mathrm{ft}$ (well TM1035, fig. 10). The total annual recharge to the contiguous unconfined aquifer is $2.56 \mathrm{ft}^{3} / \mathrm{s}(1.65 \mathrm{Mgal} / \mathrm{d}$; table 2). In order to provide sustainable continuous amount of water to large water users such as municipalities and industries, an array of wells spaced along this aquifer (for example, wells that are spaced $500 \mathrm{ft}$ apart along the center of the aquifer, each screened in the bottom $5 \mathrm{ft}$ of the aquifer) could probably be pumped collectively at a rate of several hundred gallons per minute during the winter and spring of most years. Water from Danby Creek would readily infiltrate and recharge the aquifer. However, the potential for induced recharge (when a pumping well creates a cone of depression that lowers an adjacent water table below the level of a stream causing the stream to lose water to the adjacent groundwater aquifer) from Danby Creek during summer periods and dry years of low flow is likely to be inadequate to sustain this rate of withdrawal. In addition, the amount of water stored in this thin, and limited in extent, aquifer would be small. If development of the unconfined aquifer in the Danby Creek valley was contemplated, test wells would need to be drilled to collect more detailed data about the saturated thickness and aquifer transmissivity in order to determine the potential yield more precisely.

\section{Confined Aquifers in Upper Buttermilk Creek Valley}

Records of several wells document the presence of a basal confined sand and gravel aquifer over bedrock and beneath thick till in the deeply incised bedrock valley beneath Buttermilk Creek in the northern part of the study area (figs. 7, 11 , and 12 ; figs. $2-1,2-2$, and $2-5$, in appendix 2). In addition, a basal confined aquifer over bedrock and a midsection confined sand and gravel aquifer are also documented near and somewhat north of the surface-water divide between Buttermilk Creek and Danby Creek (figs. 8 and 11; appendix 2, fig. 2-2) at higher altitude than in the northern part of the study area. These aquifers may be connected, although sufficient data is lacking to conclusively determine this connection. Well data from water-well drillers through 2012 indicate that these confined aquifers are thin (typically about 
$10 \mathrm{ft}$ thick) and the reported yield data (ranged from 3 to $50 \mathrm{gal} / \mathrm{min}$; table 1). These well yield data suggest that the confined aquifers meets the needs of homeowners and small commercial facilities, but these aquifers may not be capable of supplying sufficient water to meet the needs of municipalities and industries. However, additional geohydrologic data leading to calibration of a groundwater flow model would be needed to evaluate the long-term potential yield of the confined aquifer system in upper Buttermilk Creek valley.

\section{Water Quality}

Water-quality samples were collected to characterize the chemical quality of surface water and groundwater in the study area. On July 31, 2008, seven surface-water samples were collected from seven sites, including three sites along upper Buttermilk Creek, two sites along Danby Creek, and two sites on tributaries to upper Buttermilk Creek (fig. 18). On various dates from 2007 through 2010, groundwater samples were collected from 12 wells (fig. 18). Field measurements were made for $\mathrm{pH}$, specific conductance, and water temperature for surface-water samples and groundwater samples. The concentrations of 34 constituents, including inorganic major ions, nutrients, and trace elements were measured in surface water. In 9 of the 13 wells that were sampled from August 2007 through December 2008, the concentrations of 40 constituents, including inorganic major ions, nutrients, and trace elements were measured in groundwater samples. In 4 of the 13 wells that were sampled from June 2010 through October 2010, the samples were analyzed for 20 constituents associated with hydraulic fracturing, including inorganic major ions, trace elements, radiochemicals, and dissolved gases; as well as five nutrients.

The samples were shipped by overnight delivery to the (1) USGS National Water Quality Laboratory (NWQL) in Denver, Colo., for analysis of inorganic major ions, nutrients, inorganic trace elements, and (2) USGS Chlorofluorocarbon Laboratory (CFCL) in Reston, Virginia, for select dissolved gases. Analytical results for selected constituents were compared with U.S. Environmental Protection Agency (EPA) and New York State Department of Health (NYSDOH) drinking-water standards. The standards include Maximum Contaminant Levels (MCLs), Secondary Maximum Contaminant Levels (SMCLs), Secondary Drinking-Water Standard (SDWS), and Health Advisories (HAs) established by the EPA (2009) and the NYSDOH (2011).

\section{Surface Water}

A total of 7 surface-water samples were collected by USGS personnel during base-flow conditions on July 31 , 2008 - 2 sample sites were at upper Buttermilk Creek, 3 sites were at tributaries to Buttermilk Creek, and 2 sites were at Danby Creek (tables 4 and 5, fig. 18). Summary statistics for
$\mathrm{pH}$ and several selected chemical constituents are in table 6 and summary statistics for trace elements are in table 7.

\section{Physiochemical Properties, Inorganic Major Ions, Nutrients, and Trace Elements}

The $\mathrm{pH}$ of surface-water samples ranged from 6.8 to 8.0, with a median value of 7.6 (tables 4 and 6); all of the 7 samples were within the accepted SMCL range of 6.5 to 8.5 (U.S. Environmental Protection Agency, 2009). Specific conductance of the samples ranged from 308 to 1,360 microsiemens per centimeter at 25 degrees Celsius $\left(\mu \mathrm{S} / \mathrm{cm}^{\circ} \mathrm{C}\right)$, with a median value of $341 \mu \mathrm{S} / \mathrm{cm}^{\circ} \mathrm{C}$ (tables 4 and 6).

\section{Inorganic Major lons}

The cation detected in the greatest concentration was calcium, which ranged from 33.7 to 76.4 milligrams per liter $(\mathrm{mg} / \mathrm{L})$, with a median value of $44.0 \mathrm{mg} / \mathrm{L}$ (tables 4 and 6). Magnesium concentrations ranged from 6.65 to $15.4 \mathrm{mg} / \mathrm{L}$, with a median of $8.63 \mathrm{mg} / \mathrm{L}$. Calcium and magnesium contribute to water hardness, which ranged from 112 to $254 \mathrm{mg} / \mathrm{L}$ as calcium carbonate $\left(\mathrm{CaCO}_{3}\right)$, with a median of $145 \mathrm{mg} / \mathrm{L}$. Potassium concentrations ranged from 0.57 to $1.60 \mathrm{mg} / \mathrm{L}$, with a median value of $1.15 \mathrm{mg} / \mathrm{L}$ (tables 4 and 6). Sodium concentrations ranged from 7.89 to $119 \mathrm{mg} / \mathrm{L}$, with a median value of $16.0 \mathrm{mg} / \mathrm{L}$.

The anion detected in the greatest concentration was bicarbonate, which ranged from 135 to $265 \mathrm{mg} / \mathrm{L}$, with a median value of $174 \mathrm{mg} / \mathrm{L}$ (tables 4 and 6). Chloride concentrations ranged from 15.0 to $222 \mathrm{mg} / \mathrm{L}$, with a median value of $25.0 \mathrm{mg} / \mathrm{L}$. Silica concentrations ranged from 4.34 to $10.5 \mathrm{mg} / \mathrm{L}$, with a median value of $5.28 \mathrm{mg} / \mathrm{L}$ (tables 4 and 6). Sulfate concentrations ranged from 1.62 to $11.9 \mathrm{mg} / \mathrm{L}$, with a median value of $6.22 \mathrm{mg} / \mathrm{L}$. None of the common major ions collected form surface-water sites in the study area exceeded any Federal or State water-quality standards (table 6) except for one sample, which exceeded the EPA drinking-water quality taste threshold of $60 \mathrm{mg} / \mathrm{L}$ for sodium.

\section{Nutrients}

The nutrient detected in the greatest concentration was nitrate (as nitrite plus nitrate, $\mathrm{NO}_{2}+\mathrm{NO}_{3}$, tables 4 and 6), which ranged in concentrations from 0.022 to $0.454 \mathrm{mg} / \mathrm{L}$ as nitrogen, with a median value of $0.06 \mathrm{mg} / \mathrm{L}$ (tables 4 and 6). High concentrations of nitrogen can cause excessive plant and algal growth in streams, depleting oxygen and stressing organisms in their aquatic habitat; high concentrations also are a human health concern when the concentration is more than $10 \mathrm{mg} / \mathrm{L}$ in drinking water (U.S. Environmental Protection Agency, 2009). Nitrite concentrations were at or below the reporting limit of $0.002 \mathrm{mg} / \mathrm{L}$ as nitrogen. Orthophosphate concentrations ranged from an estimated low of 0.005 to 


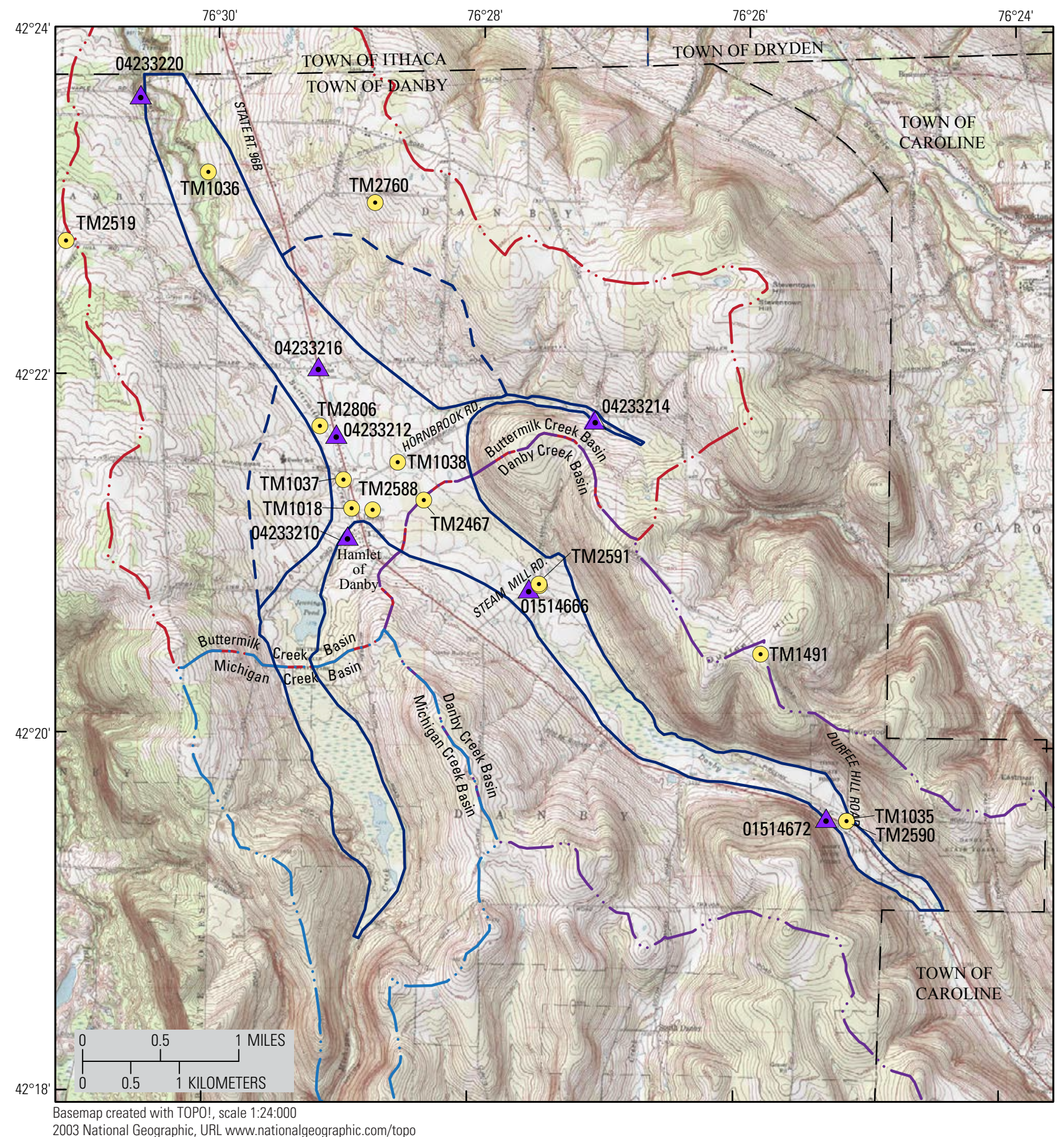

\section{EXPLANATION}

Aquifer boundary - Dashed lines bound areas on the sides of the valley where bedrock is overlain chiefly by till and some thin beds of sand and gravel that form local confined aquifers. It is unknown whether these local aquifers are hydraulically connected to the aquifer(s) in the valley

\section{Basin boundary-Variously colored}
- 04233216
Surface-water sampling site and site identification number in which water-quality sample was collected-Analyses are in table 4
$\odot$ TM2467
Well and well site name in which groundwater sample was collected — Analyses are in tables 8,9 , and 10

Figure 18. The location of groundwater and surface-water sampling sites in upper Buttermilk Creek and Danby Creek valleys, Town of Danby, Tompkins County, New York. 
Table 4. Physiochemical properties of, and concentrations of inorganic major ions and nutrients in surface-water samples from Buttermilk Creek, selected tributaries to Buttermilk Creek, and Danby Creek, Town of Danby, New York, July 31, 2008.

[Trib, tributary; Parm code, USGS National Water Information System (NWIS) parameter code; $\mathrm{mg} / \mathrm{L}$, milligrams per liter; $\mu \mathrm{S} / \mathrm{cm}$, microsiemens per centimeter at 25 degrees Celcius; ${ }^{\circ} \mathrm{C}$, degrees Celsius; $\mathrm{CaCO}_{3}$, calcium carbonate; <, less than; $\mathrm{N}$, nitrogen; $\mathrm{P}$, phosphorous; e, estimated value — constituent was detected in the sample but with low or inconsistent recovery; $\mathrm{ft}^{3} / \mathrm{s}$, cubic foot per second. Sampling site locations are shown in figure 18.]

\begin{tabular}{|c|c|c|c|c|c|c|c|c|c|}
\hline & \multicolumn{2}{|c|}{ Local name } & $\begin{array}{c}\text { Buttermilk } \\
\text { Creek at } \\
\text { Danby }\end{array}$ & $\begin{array}{l}\text { Buttermilk } \\
\text { Creek } \\
\text { South of } \\
\text { Ithaca }\end{array}$ & $\begin{array}{l}\text { Buttermilk } \\
\text { Creek } \\
\text { Trib } 1 \text { at } \\
\text { SR-96B at } \\
\text { Danby }\end{array}$ & $\begin{array}{l}\text { Buttermilk } \\
\text { Creek } \\
\text { Trib } 2 \text { at } \\
\text { Nelson } \\
\text { Road near } \\
\text { Danby }\end{array}$ & $\begin{array}{l}\text { Buttermilk } \\
\text { Creek } \\
\text { Trib } 2 \text { at } \\
\text { Danby }\end{array}$ & $\begin{array}{c}\text { Danby } \\
\text { Creek at } \\
\text { Steam Mill } \\
\text { Road near } \\
\text { Danby }\end{array}$ & $\begin{array}{c}\text { Danby } \\
\text { Creek at } \\
\text { SR-96B near } \\
\text { Willseyville }\end{array}$ \\
\hline & \multicolumn{2}{|c|}{ Date sampled } & 7/31/2008 & 7/31/2008 & $7 / 31 / 2008$ & 7/31/2008 & 7/31/2008 & $7 / 31 / 2008$ & 7/31/2008 \\
\hline \multicolumn{3}{|c|}{ USGS station identification number } & 04233210 & 04233220 & 04233212 & 04233214 & 04233216 & 01514666 & 01514672 \\
\hline Physiochemical properties & $\begin{array}{l}\text { Parm } \\
\text { code }\end{array}$ & Units & \multicolumn{7}{|c|}{ Values of physiochemical properties } \\
\hline $\begin{array}{l}\text { Dissolved oxygen (field, } \\
\text { standard units) }\end{array}$ & 00300 & $\mathrm{mg} / \mathrm{L}$ & 6.5 & 6.8 & 1.7 & 7.0 & 6.0 & 3.5 & 5.5 \\
\hline pH (field, standard units) & 00400 & $\mathrm{pH}$ & 7.6 & 8.0 & 7.4 & 7.5 & 7.8 & 6.8 & 7.6 \\
\hline $\begin{array}{l}\text { Specific conductance, at } 25 \\
{ }^{\circ} \mathrm{C} \text { (field) }\end{array}$ & 00095 & $\mu \mathrm{S} /$ & 341 & 457 & 1,360 & 326 & 413 & 325 & 308 \\
\hline $\begin{array}{l}\text { Water temperature (field, } \\
\text { standard units) }\end{array}$ & 00010 & ${ }^{\circ} \mathrm{C}$ & 19.5 & 19.3 & 18.0 & 19.5 & 17.5 & 23.0 & 23.3 \\
\hline $\begin{array}{l}\text { Stream discharge, instan- } \\
\text { taneous }\end{array}$ & 00061 & $\mathrm{ft}^{3} / \mathrm{s}$ & 0.05 & 0.88 & 0.001 & 0.08 & 0.34 & 0.03 & 0.72 \\
\hline \multicolumn{3}{|l|}{ Constituent } & \multicolumn{7}{|c|}{ Concentrations of inorganic major ions } \\
\hline \multicolumn{10}{|l|}{ Cations: } \\
\hline Calcium, filtered & 00915 & $\mathrm{mg} / \mathrm{L}$ & 38.0 & 57.6 & 76.4 & 44.0 & 57.3 & 39.5 & 33.7 \\
\hline Magnesium, filtered & 00925 & $\mathrm{mg} / \mathrm{L}$ & 7.93 & 10.6 & 15.4 & 8.63 & 9.76 & 7.4 & 6.65 \\
\hline Potassium, filtered & 00935 & $\mathrm{mg} / \mathrm{L}$ & 0.97 & 1.60 & 1.44 & 1.15 & 1.34 & 1.03 & 0.57 \\
\hline Sodium, filtered & 00930 & $\mathrm{mg} / \mathrm{L}$ & 16.2 & 17.5 & 119 & 7.89 & 10.5 & 12.1 & 16.0 \\
\hline \multicolumn{10}{|l|}{ Anions: } \\
\hline $\begin{array}{l}\text { Bicarbonate, filtered, as } \\
\mathrm{CaCO}_{3}\end{array}$ & CALC $^{a}$ & $\mathrm{mg} / \mathrm{L}$ & 154 & 222 & 265 & 174 & 223 & 170 & 135 \\
\hline Chloride, filtered & 00940 & $\mathrm{mg} / \mathrm{L}$ & 25.4 & 28.5 & 222 & 15.0 & 19.1 & 17.7 & 25.0 \\
\hline Silica, filtered & 00955 & $\mathrm{mg} / \mathrm{L}$ & 4.36 & 4.34 & 10.5 & 5.95 & 5.28 & 7.38 & 4.71 \\
\hline Sulfate, filtered & 00945 & $\mathrm{mg} / \mathrm{L}$ & 6.22 & 11.9 & 7.95 & 3.88 & 11.0 & 1.62 & 4.81 \\
\hline Hardness, filtered & 00900 & $\mathrm{mg} / \mathrm{L}$ & 127 & 188 & 254 & 145 & 183 & 129 & 112 \\
\hline Alkalinity, filtered $\mathrm{CaCO}_{3}$ & 29801 & $\mathrm{mg} / \mathrm{L}$ & 126 & 182 & 217 & 143 & 177 & 139 & 111 \\
\hline Dissolved solids, at $180^{\circ} \mathrm{C}$ & 70300 & $\mathrm{mg} / \mathrm{L}$ & 210 & 271 & 654 & 210 & 247 & 224 & 195 \\
\hline \multicolumn{3}{|l|}{ Nutrients } & \multicolumn{7}{|c|}{ Concentrations of nutrients } \\
\hline Ammonia, as $\mathrm{N}$, filtered & 00608 & $\mathrm{mg} / \mathrm{L}$ & $<0.02$ & $<0.02$ & 0.030 & $<0.02$ & $<0.02$ & 0.214 & 0.021 \\
\hline $\begin{array}{l}\text { Nitrate, as } \mathrm{N}, \mathrm{NO}_{2}+\mathrm{NO}_{3} \text {, } \\
\quad \text { filtered as nitrogen }\end{array}$ & 00631 & $\mathrm{mg} / \mathrm{L}$ & 0.454 & e 0.022 & 0.040 & 0.15 & 0.162 & e 0.03 & 0.06 \\
\hline Nitrite, as $\mathrm{N}$, filtered & 00613 & $\mathrm{mg} / \mathrm{L}$ & e 0.002 & $<0.002$ & e 0.002 & e 0.002 & $<0.002$ & 0.002 & e 0.002 \\
\hline $\begin{array}{l}\text { Orthophosphate, as } \mathrm{P}, \\
\text { filtered }\end{array}$ & 00671 & $\mathrm{mg} / \mathrm{L}$ & 0.021 & e 0.005 & 0.028 & 0.007 & 0.008 & 0.040 & 0.015 \\
\hline Phosphorus, unfiltered & 00665 & $\mathrm{mg} / \mathrm{L}$ & 0.031 & e 0.004 & 0.105 & e 0.006 & e 0.006 & 0.117 & 0.067 \\
\hline
\end{tabular}

\footnotetext{
${ }^{a} \mathrm{CALC}=$ Bicarbonate values were calculated from alkalinity concentrations, which are given in milligrams per liter of $\mathrm{CaCO}_{3}$.
} 
Table 5. Concentrations of trace elements in surface-water samples from Buttermilk Creek, selected tributaries to Buttermilk Creek, and Danby Creek, Town of Danby, New York, July 31, 2008.

[Trib, tributary; Parm code, USGS National Water Information System (NWIS) parameter code; $\mu \mathrm{g} / \mathrm{L}$, micrograms per liter; <, less than; e, estimated. Sampling site locations are shown in figure 18.]

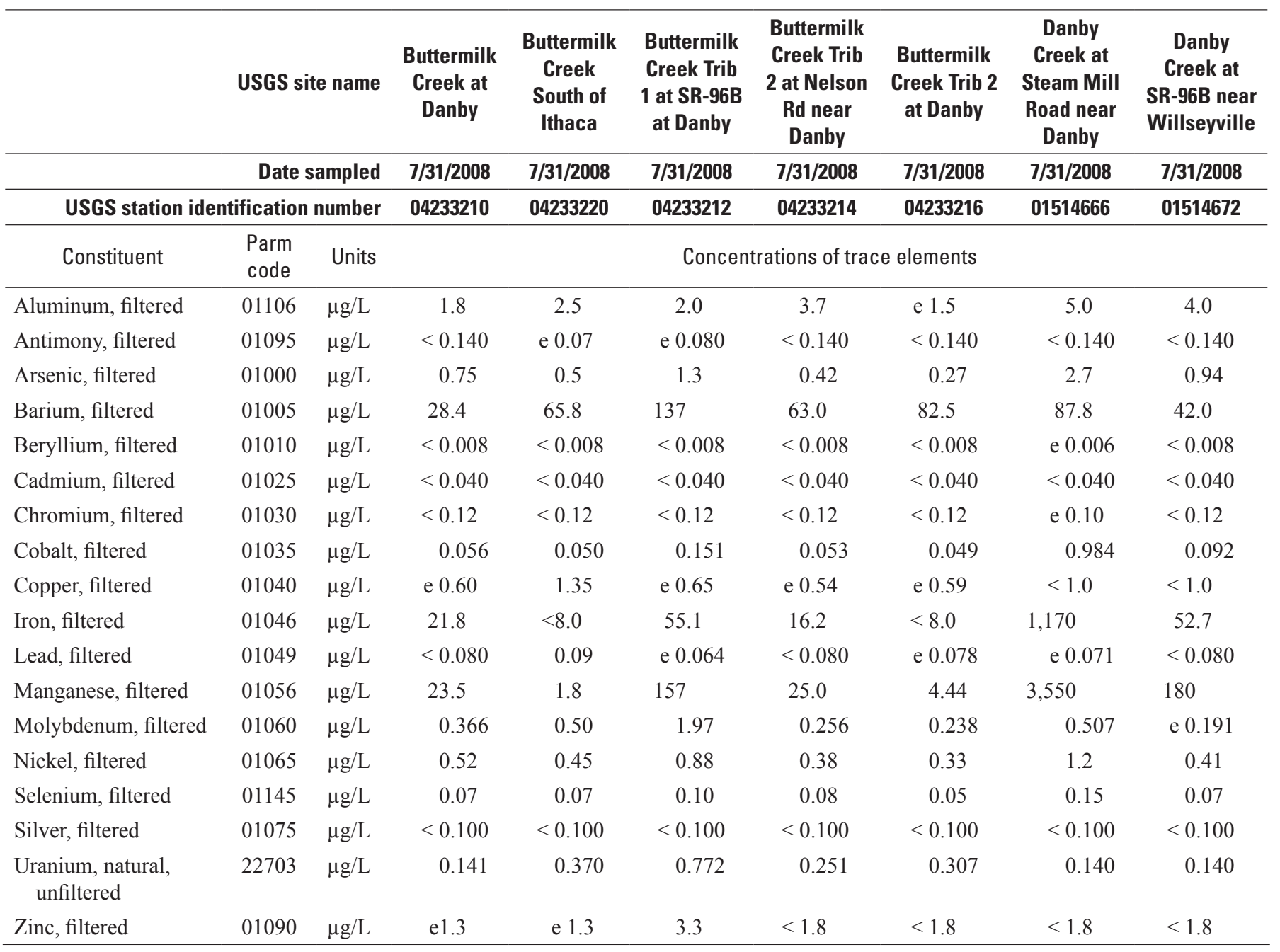

$0.028 \mathrm{mg} / \mathrm{L}$ as phosphorous, with a median value of 0.015 (tables 4 and 6). None of the surface-water samples exceeded drinking-water standards for nitrate or nitrite.

\section{Trace Elements}

The trace elements detected in the highest concentrations were barium, which ranged in concentrations from 24.8 to 137 micrograms per liter $(\mu \mathrm{g} / \mathrm{L})$, with a median of $65.8 \mu \mathrm{g} / \mathrm{L}$; iron, which ranged in concentrations from $<8.0$ to $1,170 \mu \mathrm{g} / \mathrm{L}$, with a median $21.8 \mu \mathrm{g} / \mathrm{L}$; and manganese, which ranged in concentrations from 1.8 to $3,550 \mu \mathrm{g} / \mathrm{L}$, with a median $25.0 \mu \mathrm{g} / \mathrm{L}$ (table 7). The highest detected concentration of a trace element was $3,550 \mu \mathrm{g} / \mathrm{L}$ of manganese in a sample from a stream (USGS streamgage 01514666, table 5) that drains a wetland area. Drinking-water standards were not exceeded for trace chemicals except for the sample collected at USGS streamgage 01514666 in which the concentration of iron was $1,170 \mu \mathrm{g} / \mathrm{L}$, which exceeded the EPA SMCL of $300 \mu \mathrm{g} / \mathrm{L}$, and the concentration of manganese was $3,550 \mu \mathrm{g} / \mathrm{L}$, which exceeded the EPA SMCL of $300 \mu \mathrm{g} / \mathrm{L}$ (table 5).

\section{Groundwater}

Groundwater samples were collected from 13 wells that tap the stratified-drift and bedrock aquifers - seven samples were from the confined stratified-drift aquifers, one from an unconfined stratified-drift aquifer, and five were from bedrock aquifers (locations shown in fig. 18). Nine samples were analyzed for physiochemical properties and 
政

흔으

흥응

离

을 웅

额

六

的

흔 뭉

䒕

Ð

品

过

焉

흥

흠

정 辰

당

당

을

言比

흔

얼

.

密 市

$\geq$ 음

壱

क $\stackrel{.}{.}$

๑ 잉

을

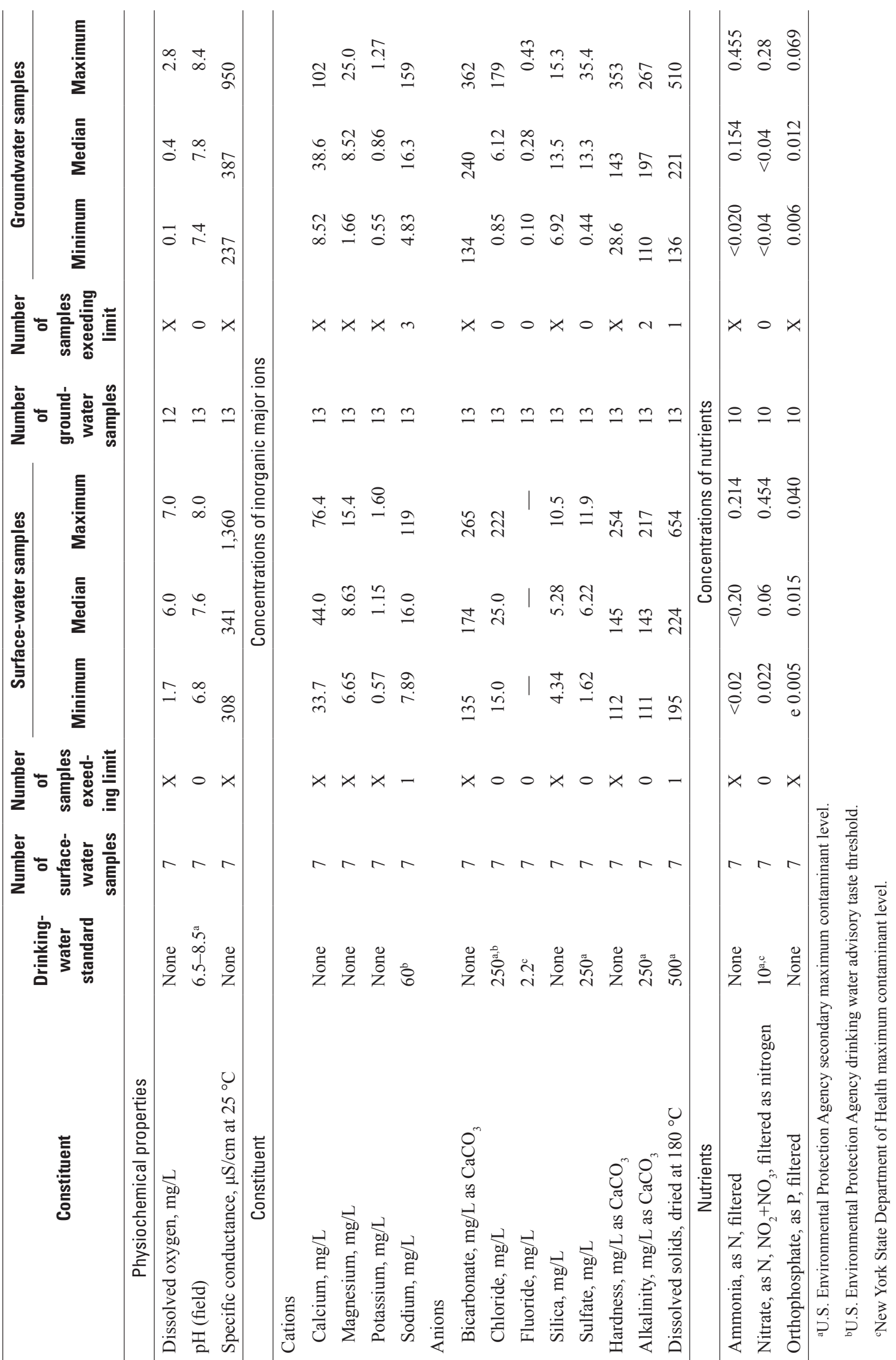




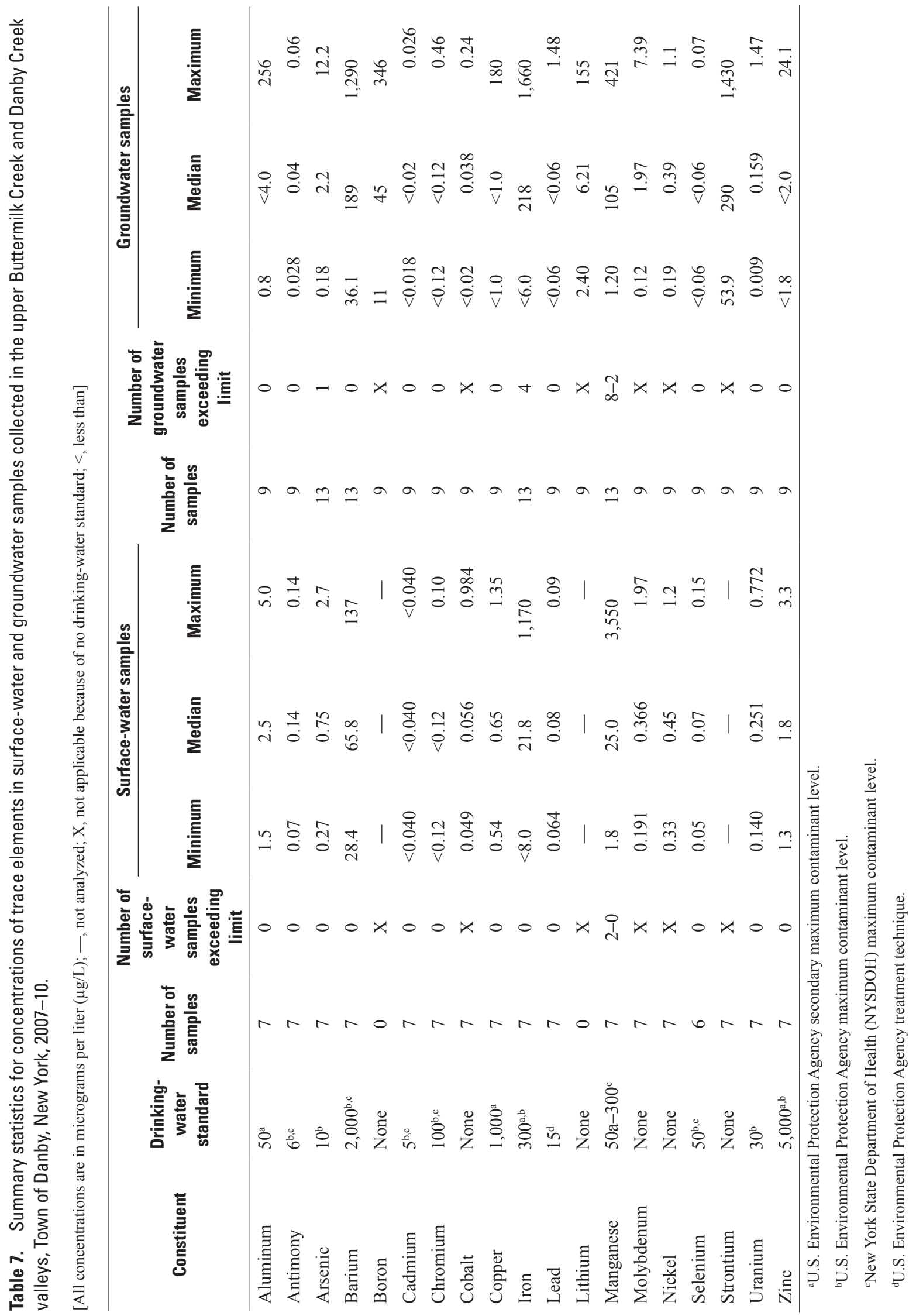


Water Quality 37

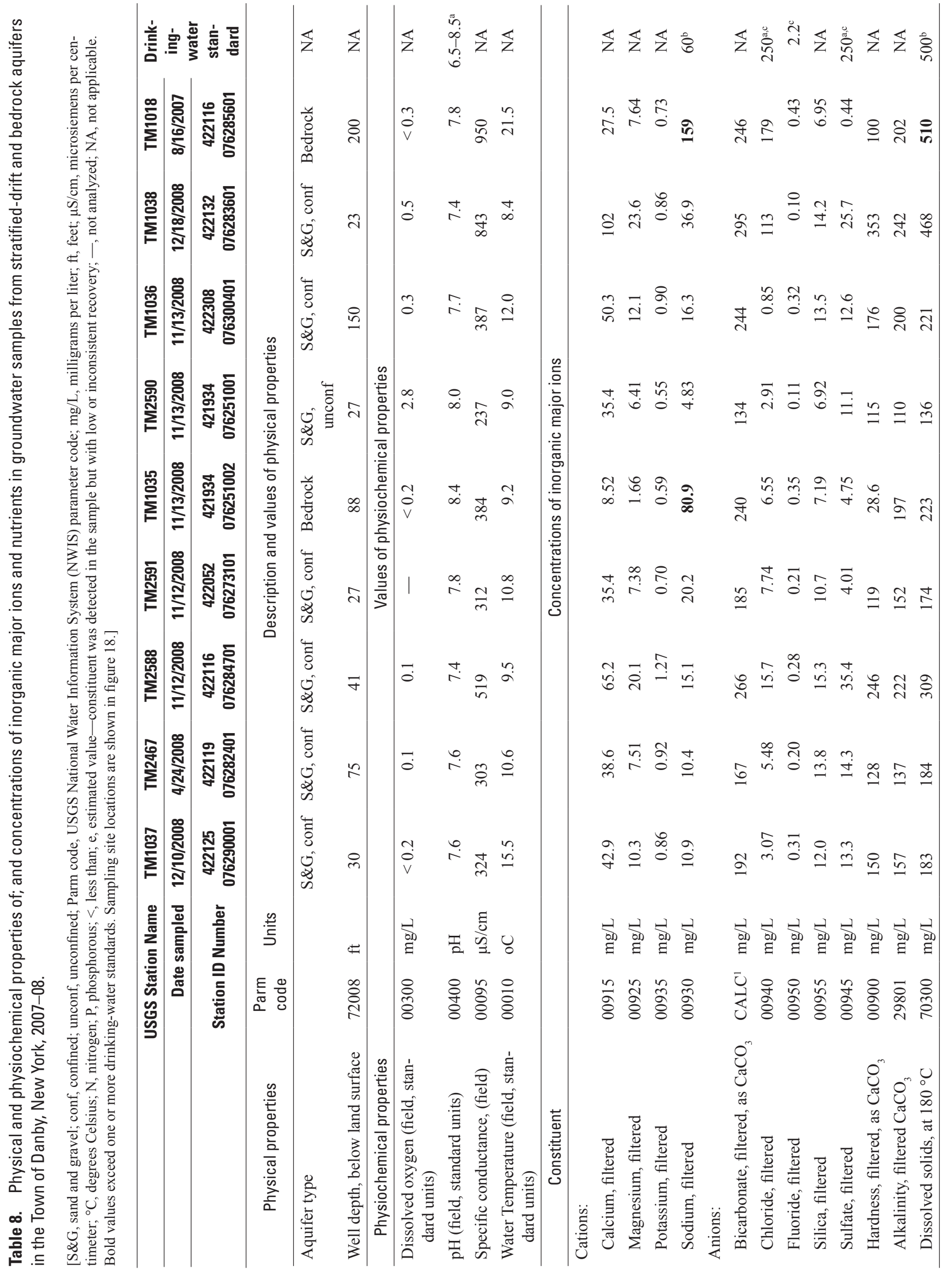




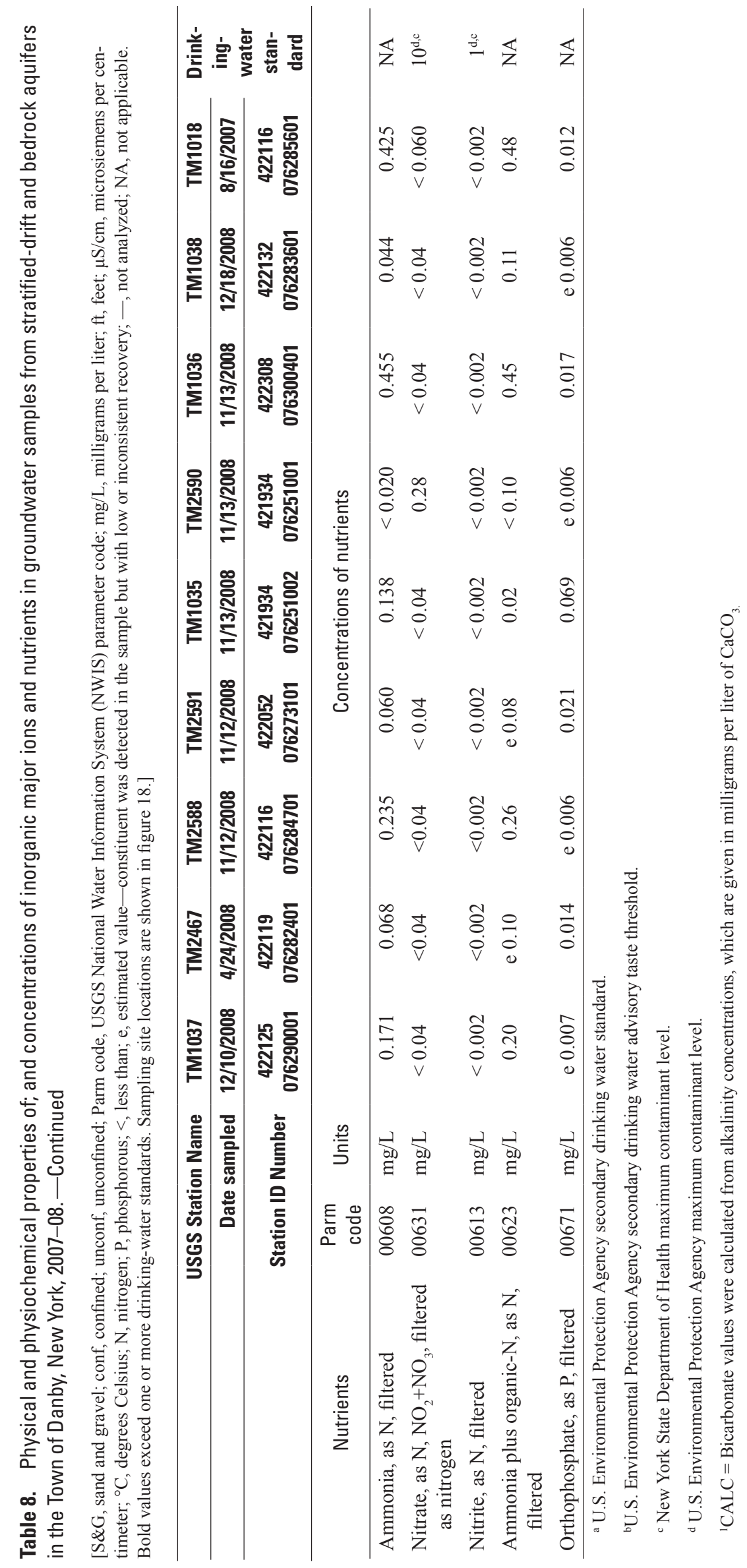




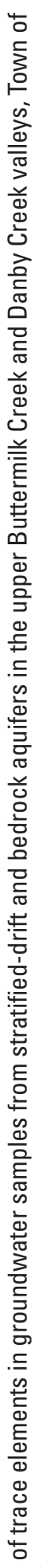

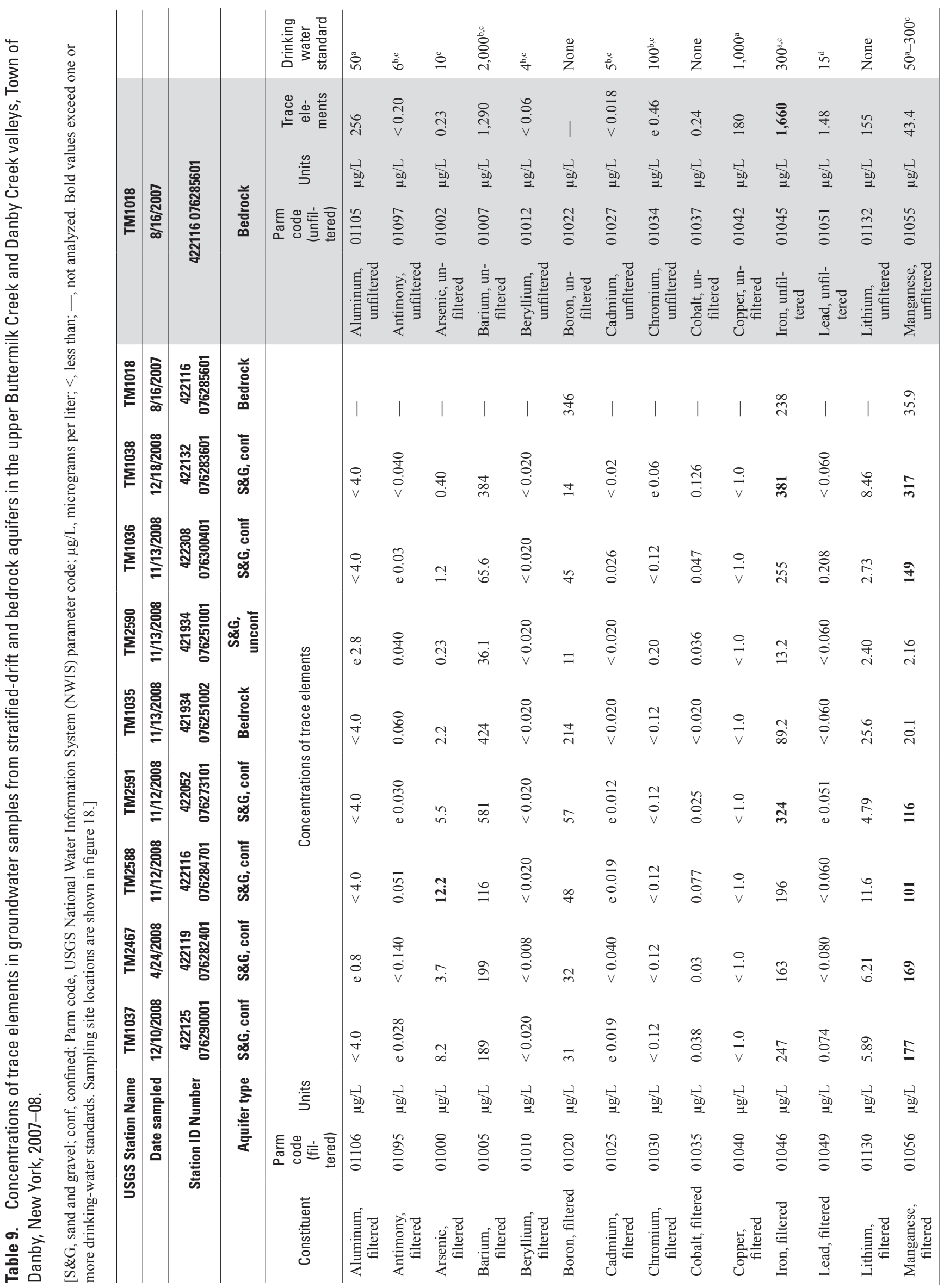




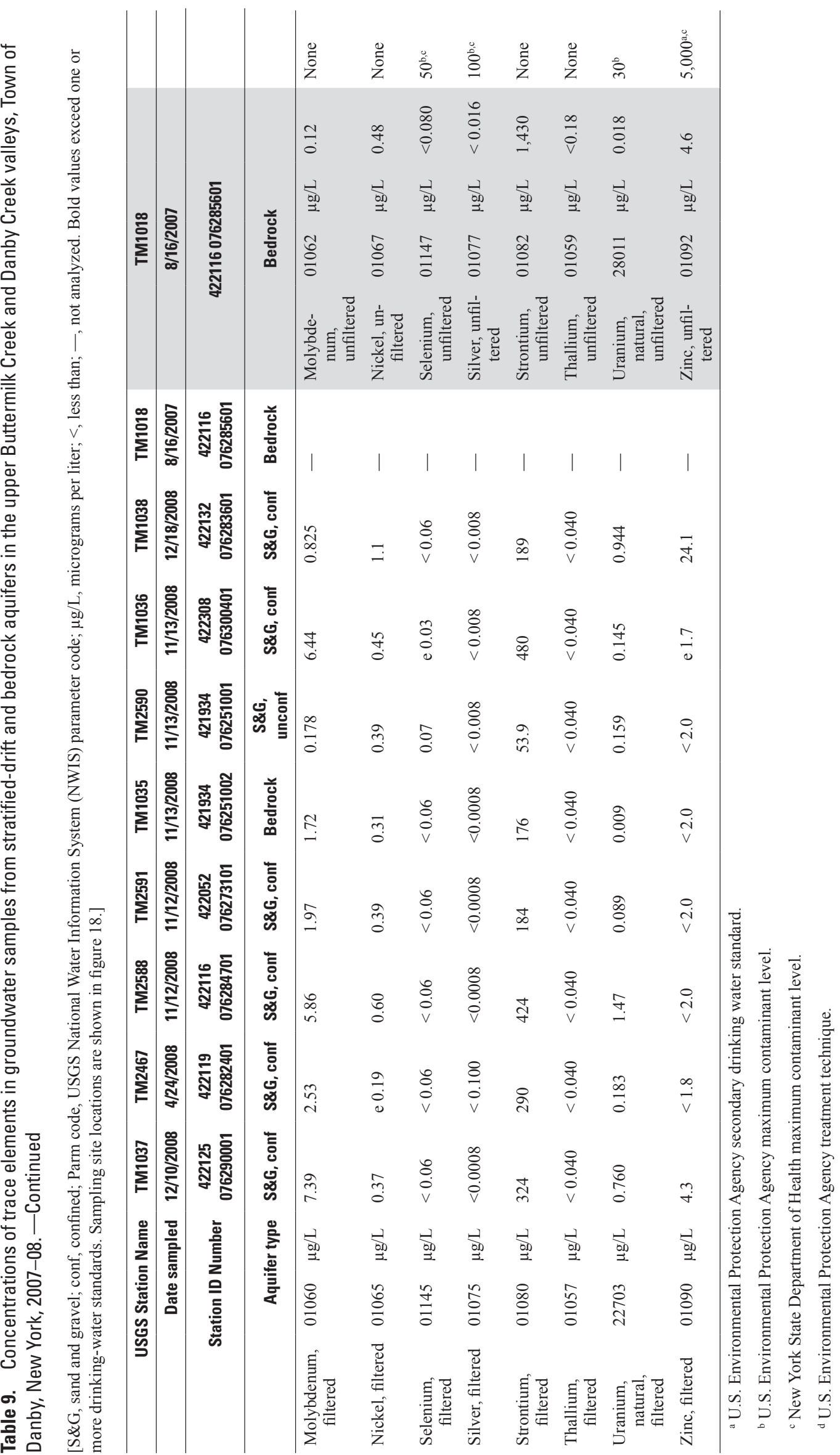


chemical constituents (inorganic major ions, nutrients, and trace metals) that typically characterize the general water quality (tables 8 and 9). In addition, to obtain background data because of concerns about natural-gas drilling, four samples were analyzed for physiochemical properties and selected chemical constituents including inorganic major ions, nutrients, trace elements, bromide, radiochemical constituents [gross alpha and gross beta], methane, and other dissolved gases (table 10). Three groundwater samples were from the Town of Danby owned facilities (TM1037, Danby Fire Hall; TM2467, Highway Department; and TM1018, Town Hall), five were from private homes (TM1036, TM1038, TM2519, TM2760, and TM1491), and five were from test wells drilled for this study (TM2588, TM2591, TM1035, TM2590, and TM2806). Dissolved oxygen, $\mathrm{pH}$, specific conductance, and water temperature were measured in the field. Samples were analyzed for inorganic major ions, nutrients, and trace elements by the USGS NWQL in Denver, Colo. Results of chemical analyses are tabulated in tables 8,9 , and 10 , and summary statistics of selected chemical constituents are in tables 6 and 7 .

\section{Physical and Physiochemical Properties}

Wells that were sampled ranged from 23 to $420 \mathrm{ft}$ deep and the $\mathrm{pH}$ ranged from 7.4 to 8.4 , with a median value of 7.8 (tables 6, 8, and 10); no $\mathrm{pH}$ measurement was outside the accepted EPA SMCL range of 6.5 to 8.5. Specific conductance of the samples ranged from 237 to $950 \mu \mathrm{S} / \mathrm{cm}$, with a median value of $387 \mu \mathrm{S} / \mathrm{cm}$ (tables 6,8 , and 10 ).

\section{Inorganic Major lons}

The cation that was detected with the largest concentration was calcium, which ranged from 8.52 to $102 \mathrm{mg} / \mathrm{L}$, with a median value of $38.6 \mathrm{mg} / \mathrm{L}$ (tables 6 , 8 , and 10). Magnesium concentrations ranged from 1.66 to $25.0 \mathrm{mg} / \mathrm{L}$, with a median value of $8.52 \mathrm{mg} / \mathrm{L}$. Sodium concentrations ranged from 4.83 to $159 \mathrm{mg} / \mathrm{L}$, with a median value of $16.3 \mathrm{mg} / \mathrm{L}$. The concentrations of sodium in three samples from the bedrock aquifer exceeded the EPA Drinking Water Advisory Taste Threshold of $60 \mathrm{mg} / \mathrm{L}$ (tables 8 and 10) (U.S. Environmental Protection Agency, 2009). No samples from the sand and gravel aquifer exceeded the EPA Drinking Water Advisory Taste Threshold (U.S. Environmental Protection Agency, 2009). Potassium concentrations were detected in low concentrations in the study area (generally less than $1.0 \mathrm{mg} / \mathrm{L}$ ). Potassium concentrations ranged from 0.55 to $1.27 \mathrm{mg} / \mathrm{L}$, with a median value of $0.86 \mathrm{mg} / \mathrm{L}$ (tables 6,8 , and $10)$.

Calcium and magnesium contribute to water hardness as $\mathrm{CaCO}_{3}$, which ranged from 28.6 to $353 \mathrm{mg} / \mathrm{L}$, with a median value of $143 \mathrm{mg} / \mathrm{L}$ (tables 6,8 , and 10). Of the 13 samples, one was soft ( 0 to $60 \mathrm{mg} / \mathrm{L}$ as $\mathrm{CaCO}_{3}$ ), four were moderately hard (61 to $120 \mathrm{mg} / \mathrm{L}$ as $\mathrm{CaCO}_{3}$ ), and four were hard (121 to
$180 \mathrm{mg} / \mathrm{L}$ as $\mathrm{CaCO}_{3}$ ), and four were very hard water (Hem, 1985). Hard and very hard water consumes excessive amounts of soap and detergents and forms an insoluble scum or scale (Hem, 1985).

Alkalinity, which results from dissolution of carbonate minerals such as those composing limestone and dolomite and is a measure of the capacity of water to neutralize acid, ranged from 110 to $267 \mathrm{mg} / \mathrm{L}$ as $\mathrm{CaCO}_{3}$, with a median value of $197 \mathrm{mg} / \mathrm{L}$ of $\mathrm{CaCO}_{3}$ (tables 6, 8, and 10). Alkalinity concentrations lower than $100 \mathrm{mg} / \mathrm{L}$ can be corrosive when $\mathrm{pH}$ is low (below $\mathrm{pH} \mathrm{6);} \mathrm{when} \mathrm{alkalinity} \mathrm{is} \mathrm{greater} \mathrm{than}$ $150 \mathrm{mg} / \mathrm{L}$, it can cause scale (lime) buildup in plumbing pipes (Mechenich and Andrews, 2004). Dissolved solids concentrations ranged from 136 to $510 \mathrm{mg} / \mathrm{L}$ (tables 6,8 and 10), with a median value of $221 \mathrm{mg} / \mathrm{L}$; the dissolved solids concentration in one sample from a well that taps the bedrock aquifer (TM1018) exceeded the EPA SDWS for dissolved solids of $500 \mathrm{mg} / \mathrm{L}$.

The anion detected with the largest concentration was bicarbonate, which ranged from 134 to $362 \mathrm{mg} / \mathrm{L}$, with a median value of $240 \mathrm{mg} / \mathrm{L}$ (tables 6, 8, and 10). Bicarbonate values were calculated from alkalinity concentrations, which are given in milligrams per liter of $\mathrm{CaCO}_{3}$. Chloride concentrations ranged from and 0.85 to $179 \mathrm{mg} / \mathrm{L}$, with median value of 6.12 (tables 6,8 , and 10). The concentrations of chloride did not exceed the NYSDOH MCL and EPA SDWS of $250 \mathrm{mg} / \mathrm{L}$. Silica concentrations ranged from and 6.92 to $15.3 \mathrm{mg} / \mathrm{L}$, with a median value of 13.5 (tables 6,8 , and 10 ). Sulfate concentrations ranged from 0.44 to $35.4 \mathrm{mg} / \mathrm{L}$, with a median value of $13.3 \mathrm{mg} / \mathrm{L}$ (tables 6,8 , and 10). The concentration of sulfate did not exceed the NYSDOH MCL and EPA SDWS of $250 \mathrm{mg} / \mathrm{L}$.

\section{Nutrients}

The dominant nutrient detected in groundwater samples in the upper Buttermilk Creek and Danby Creek valleys was ammonia (table 8). The concentration of ammonia ranged from less than $(<) 0.020$ to $0.455 \mathrm{mg} / \mathrm{L}$ as nitrogen $(\mathrm{N})$, with a median value of $0.154 \mathrm{mg} / \mathrm{L}$ as $\mathrm{N}$ (tables 6,8 , and 10). In this report, the medians of data that included censored data (values of concentrations less than the reporting limit) were calculated by sorting those concentrations that had less than values at the smallest end of the range of values. Ammonia was detected in all samples from wells that were finished in confined sand and gravel aquifers and the bedrock aquifer, but was not detected in the sample from well TM2590; this well was finished in the unconfined aquifer. The concentrations of nitrate plus nitrite $\left(\mathrm{NO}_{2}+\mathrm{NO}_{3}\right)$ and of nitrite did not exceed the NYSDOH and EPA MCLs of $10 \mathrm{mg} / \mathrm{L}$ as $\mathrm{N}$ and $1 \mathrm{mg} / \mathrm{L}$ as $\mathrm{N}$, respectively, in any sample. Nitrate was in a concentration above the detection limit of $0.04 \mathrm{mg} / \mathrm{L}$ in only one sample$0.28 \mathrm{mg} / \mathrm{L}$, which was from well TM2590 that was finished in the unconfined aquifer. Nitrite was not detected in any sample above the reporting limit of $0.002 \mathrm{mg} / \mathrm{L}$. The concentrations of orthophosphate ranged from an estimated minimum of 
Table 10. Physical and physiochemical properties of; and concentrations of inorganic major ions, trace elements, nutrients, selected radiochemicals, and dissolved gases in groundwater samples from bedrock and stratified-drift aquifers in the Town of Danby, New York, 2010.

[S\&G, sand and gravel; conf, confined aquifer; Parm code, USGS National Water Information System (NWIS) parameter code; mg/L, milligrams per liter; $\mu \mathrm{g} / \mathrm{L}$, micrograms per liter; ${ }^{\circ} \mathrm{C}$, degrees Celsius; e, estimated; $\mathrm{ft}$, feet; $<$, less than; —, not analyzed; picocurie per liter (pCi/L); R, radchem nondetect. Bold values exceed one or more drinking-water standards. Sampling site locations are shown in figure 18.]

\begin{tabular}{|c|c|c|c|c|c|c|c|}
\hline & USGS Stat & n Name & TM2519 & TM2760 & TM1491 & TM2806 & \multirow{3}{*}{$\begin{array}{l}\text { Drinking } \\
\text { water } \\
\text { standarc }\end{array}$} \\
\hline & \multicolumn{2}{|c|}{ Date sampled } & 6/2/2010 & 6/2/2010 & 6/2/2010 & 10/28/2010 & \\
\hline & \multicolumn{2}{|c|}{ Station ID Number } & $\begin{array}{c}422244 \\
076310701\end{array}$ & $\begin{array}{c}422254 \\
076284801\end{array}$ & $\begin{array}{c}422029 \\
076255001\end{array}$ & $\begin{array}{c}422143 \\
076291101\end{array}$ & \\
\hline Physical properties & $\begin{array}{l}\text { Parm } \\
\text { code }\end{array}$ & Units & \multicolumn{4}{|c|}{ Description and values of physical properties } & \\
\hline Aquifer type & & & Shale & Shale & Shale & S\&G, conf. & None \\
\hline Well depth, below land surface & 72008 & $\mathrm{ft}$ & 420 & 177 & 300 & 47 & None \\
\hline Physiochemical properties & \multicolumn{7}{|c|}{ Values of physiochemical properties } \\
\hline Dissolved oxygen (field, standard units) & 00300 & $\mathrm{mg} / \mathrm{L}$ & 1.8 & 0.7 & 0.7 & 1.0 & None \\
\hline pH (field, standard units) & 00400 & $\mathrm{pH}$ & 8.2 & 7.6 & 7.8 & 7.9 & $6.5-8.5^{\mathrm{b}}$ \\
\hline Specific conductance, at $25^{\circ} \mathrm{C}$ (field) & 00095 & $\mu \mathrm{S} / \mathrm{cm}$ & 661 & 598 & 328 & 398 & None \\
\hline Water temperature (field, standard units) & 00010 & ${ }^{\circ} \mathrm{C}$ & 13.5 & 12.0 & 11.6 & 10.8 & None \\
\hline Constituent & \multicolumn{7}{|c|}{ Concentrations of inorganic major ions } \\
\hline \multicolumn{8}{|l|}{ Cations: } \\
\hline Calcium, filtered & 00915 & $\mathrm{mg} / \mathrm{L}$ & 34.4 & 71.5 & 43.3 & 52.4 & None \\
\hline Magnesium, filtered & 00925 & $\mathrm{mg} / \mathrm{L}$ & 7.7 & 25.0 & 8.52 & 14 & None \\
\hline Potassium, filtered & 00935 & $\mathrm{mg} / \mathrm{L}$ & 0.72 & 0.81 & 0.57 & 0.94 & None \\
\hline Sodium, filtered & 00930 & $\mathrm{mg} / \mathrm{L}$ & 104 & 26.0 & 14.5 & 10.0 & $60^{c}$ \\
\hline \multicolumn{8}{|l|}{ Anions: } \\
\hline Bicarbonate, filtered, as $\mathrm{CaCO}_{3}$ & CALC $^{1}$ & $\mathrm{mg} / \mathrm{L}$ & 315 & 362 & 183 & 231 & None \\
\hline Bromide, filtered & 71870 & $\mathrm{mg} / \mathrm{L}$ & 0.274 & e 0.020 & e 0.019 & 0.021 & None \\
\hline Chloride, filtered & 00940 & $\mathrm{mg} / \mathrm{L}$ & 51.3 & 1.59 & 4.10 & 6.12 & $250^{\mathrm{b}, \mathrm{d}}$ \\
\hline Fluoride, filtered & 00950 & $\mathrm{mg} / \mathrm{L}$ & 0.72 & 0.21 & 0.19 & 0.29 & $2.2^{\mathrm{d}}$ \\
\hline Silica, filtered & 00955 & $\mathrm{mg} / \mathrm{L}$ & 10.9 & 13.6 & 14.4 & 15.3 & None \\
\hline Sulfate, filtered & 00945 & $\mathrm{mg} / \mathrm{L}$ & 5.82 & 32.3 & 17.2 & 19.2 & $250^{\mathrm{b}, \mathrm{d}}$ \\
\hline Hardness, filtered, as $\mathrm{CaCO}_{3}$ & 00900 & $\mathrm{mg} / \mathrm{L}$ & 118 & 282 & 143 & 189 & None \\
\hline Alkalinity, filtered, as $\mathrm{CaCO}_{3}$ & 29801 & $\mathrm{mg} / \mathrm{L}$ & 258 & 267 & 150 & 189 & None \\
\hline Dissolved solids, at $180^{\circ} \mathrm{C}$ & 70300 & $\mathrm{mg} / \mathrm{L}$ & 367 & 344 & 187 & 217 & $500^{\mathrm{c}}$ \\
\hline Trace metals & \multicolumn{7}{|c|}{ Concentrations of trace elements } \\
\hline Arsenic, filtered & 01000 & $\mu \mathrm{g} / \mathrm{L}$ & 0.25 & 5.5 & 0.18 & 6.8 & $10^{\mathrm{a}, \mathrm{d}}$ \\
\hline Barium, filtered & 01005 & $\mu \mathrm{g} / \mathrm{L}$ & 304 & 76.5 & 101 & 150 & $2,000^{\mathrm{a}, \mathrm{d}}$ \\
\hline Iron, filtered & 01046 & $\mu \mathrm{g} / \mathrm{L}$ & $<6.0$ & 1,490 & $<6.0$ & 198 & $300^{\mathrm{c}, \mathrm{d}}$ \\
\hline Manganese, filtered & 01056 & $\mu \mathrm{g} / \mathrm{L}$ & 41.7 & 421 & 1.20 & 105 & $50^{\mathrm{c}}$ \\
\hline Nutrients & \multicolumn{7}{|c|}{ Concentrations of nutrients } \\
\hline Ammonia + organic $\mathrm{N}$, as $\mathrm{N}$, filtered & 00623 & $\mathrm{mg} / \mathrm{L}$ & 0.38 & 0.24 & $\mathrm{e} 0.08$ & 0.20 & None \\
\hline Ammonia, as $\mathrm{N}$, filtered & 00608 & $\mathrm{mg} / \mathrm{L}$ & - & - & - & 0.171 & None \\
\hline Nitrate, as $\mathrm{N}, \mathrm{NO}_{2}+\mathrm{NO}_{3}$, filtered & 00631 & $\mathrm{mg} / \mathrm{L}$ & - & - & - & $<0.020$ & $10^{\mathrm{a}, \mathrm{d}}$ \\
\hline Nitrite, as $\mathrm{N}$, filtered & 00613 & $\mathrm{mg} / \mathrm{L}$ & - & - & - & $<0.001$ & $1^{\mathrm{a}, \mathrm{d}}$ \\
\hline Orthophosphate, as P, filtered & 00671 & $\mathrm{mg} / \mathrm{L}$ & - & - & - & 0.011 & None \\
\hline
\end{tabular}


Table 10. Physical and physiochemical properties of; and concentrations of inorganic major ions, trace elements, nutrients, selected radiochemicals, and dissolved gases in groundwater samples from bedrock and stratified-drift aquifers in the Town of Danby, New York, 2010. - Continued

[S\&G, sand and gravel; conf, confined aquifer; Parm code, USGS National Water Information System (NWIS) parameter code; mg/L, milligrams per liter; $\mu \mathrm{g} / \mathrm{L}$, micrograms per liter; ${ }^{\circ} \mathrm{C}$, degrees Celsius; e, estimated; $\mathrm{ft}$, feet; $<$, less than; - , not analyzed; picocurie per liter (pCi/L); R, radchem nondetect. Bold values exceed one or more drinking-water standards. Sampling site locations are shown in figure 18.]

\begin{tabular}{|c|c|c|c|c|c|c|c|}
\hline & \multicolumn{2}{|c|}{ USGS Station Name } & TM2519 & TM2760 & TM1491 & TM2806 & \multirow{3}{*}{$\begin{array}{c}\text { Drinking } \\
\text { water } \\
\text { standard }\end{array}$} \\
\hline & \multicolumn{2}{|c|}{ Date sampled } & $6 / 2 / 2010$ & $6 / 2 / 2010$ & $6 / 2 / 2010$ & $10 / 28 / 2010$ & \\
\hline & \multicolumn{2}{|c|}{ Station ID Number } & 422244 & 422254 & 422029 & 422143 & \\
\hline Radiochemicals & $\begin{array}{l}\text { Parm } \\
\text { code }\end{array}$ & Units & \multicolumn{4}{|c|}{ Concentrations of radiochemicals } & \\
\hline Gross-alpha (Th-230 curve), unfiltered & 01519 & $\mathrm{pCi} / \mathrm{L}$ & 3.4 & 10.7 & R 0.5 & 2.3 & $15^{\mathrm{a}, \mathrm{d}}$ \\
\hline Gross-beta (Cs-137 curve), unfiltered & 85817 & $\mathrm{pCi} / \mathrm{L}$ & 0.9 & 19.1 & $\mathrm{R} 0.3$ & R 0.7 & $4^{\mathrm{a}, \mathrm{d}}$ \\
\hline \multicolumn{3}{|l|}{ Dissolved gases } & \multicolumn{4}{|c|}{ Concentrations of dissolved gases } & \\
\hline \multirow[t]{2}{*}{ Methane, unfiltered } & \multirow[t]{2}{*}{85574} & \multirow[t]{2}{*}{$\mathrm{mg} / \mathrm{L}$} & \multirow[t]{2}{*}{9.54} & \multirow[t]{2}{*}{0.003} & \multirow[t]{2}{*}{0.001} & \multirow[t]{2}{*}{0.005} & $10-28^{\mathrm{e}}$ \\
\hline & & & & & & & $>28^{\mathrm{f}}$ \\
\hline Nitrogen, unfiltered & 00597 & $\mathrm{mg} / \mathrm{L}$ & 19.7 & 27.6 & 25.3 & 25.1 & None \\
\hline Argon, unfiltered & 82043 & $\mathrm{mg} / \mathrm{L}$ & 0.745 & 0.919 & 0.850 & 0.839 & None \\
\hline Carbon dioxide, unfiltered & 00405 & $\mathrm{mg} / \mathrm{L}$ & 3.65 & 20.5 & 7.8 & 6.55 & None \\
\hline Oxygen, unfiltered & 62971 & $\mathrm{mg} / \mathrm{L}$ & 0.3 & 0.3 & 0.7 & 0.7 & None \\
\hline \multicolumn{8}{|c|}{ a U.S. Environmental Protection Agency maximum contaminant level. } \\
\hline \multicolumn{8}{|c|}{${ }^{\mathrm{b}}$ U.S. Environmental Protection Agency secondary drinking water standard. } \\
\hline \multicolumn{8}{|c|}{${ }^{\mathrm{c}}$ U.S. Environmental Protection Agency secondary drinking water advisory taste threshold. } \\
\hline \multicolumn{8}{|c|}{${ }^{\mathrm{d}}$ New York State Department of Health maximum contaminant level. } \\
\hline \multicolumn{8}{|c|}{${ }^{e}$ Office of Surface Mining recommends that methane concentrations be closely monitored (Eltschlager and others, 2001). } \\
\hline${ }^{\mathrm{f}}$ Office of Surface Mining recommends rem & ving ignition & ources anc & venting the $g$ & way from & fined spaces & tschlager an & s, 2001). \\
\hline
\end{tabular}

0.006 to a maximum of $0.069 \mathrm{mg} / \mathrm{L}$, with a median of 0.012 (tables 6, 8, and 10).

\section{Trace Elements}

Trace elements that were detected in every sample included arsenic, barium, boron, lithium, manganese, molybdenum, nickel, strontium, and uranium (tables 9 and 10). In general, concentrations of trace metals were higher in samples from wells that are finished in the bedrock aquifers than samples from wells finished in the confined and unconfined sand and gravel aquifers. The highest detected concentrations of trace elements were 1,660 and $1,490 \mu \mathrm{g} / \mathrm{L}$ of iron; $1,430 \mu \mathrm{g} / \mathrm{L}$ of strontium; and 1,290 of barium - all samples were from wells that are finished in the bedrock aquifer. Beryllium, silver and thallium were not detected in any samples.

Arsenic concentrations ranged from less than 0.18 to $12.2 \mu \mathrm{g} / \mathrm{L}$, with a median of $2.2 \mu \mathrm{g} / \mathrm{L}$ (tables 7,9 , and 10 ). The concentration of arsenic in one sample (well TM2588, which is finished in a confined sand and gravel aquifer) exceeded the EPA MCL of $10 \mu \mathrm{g} / \mathrm{L}$. The concentration of arsenic in another sample (well TM1037, which is also finished in a confined sand and gravel aquifer) was $8.2 \mu \mathrm{g} / \mathrm{L}$, which is slightly less than the MCL. Arsenic did not exceed the EPA MCL in samples from the bedrock aquifer or unconfined aquifers.

In the stratified-drift aquifer systems of the northern United States, elevated arsenic concentrations (greater than or equal to $10 \mu \mathrm{g} / \mathrm{L}$ ) were detected in 9 percent of samples (Thomas, 2007). In comparison, 8 of the 62 (13 percent) wells that were sampled by the USGS and the NYSDOH in the stratified-drift aquifers in Tompkins County from 2000 to 2010 had elevated arsenic concentrations. The distribution of arsenic concentrations in wells that were sampled in stratified-drift aquifers in Tompkins County are shown in figure 19. The predominant source of arsenic is iron oxides and the predominant mechanism for releasing arsenic to the ground water is reductive desorption or reductive dissolution (Thomas, 2007). Also, Thomas (2007) determined that elevated arsenic concentrations were associated with 


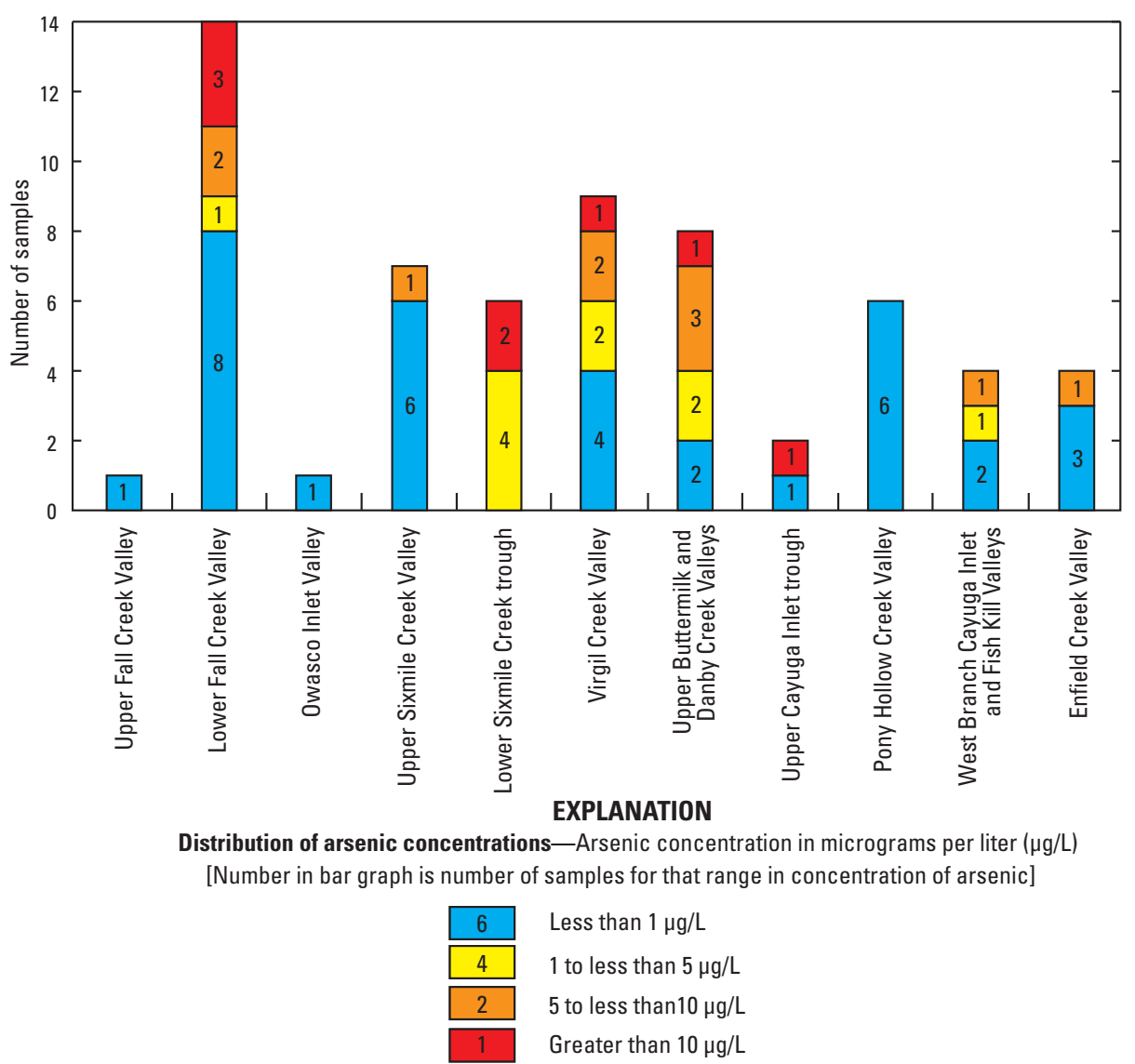

Figure 19. The distribution of arsenic concentrations from groundwater samples in stratified-drift aquifers in Tompkins County from 2000-10 in Tompkins County, New York. (Location of valleys shown in fig. 1.) strongly reducing conditions such as that in confined aquifers. A confining layer near land surface maintains reducing conditions by retarding the transport of oxygen (or other electron acceptor) from land surface. The slightly higher percentage of samples that had elevated arsenic concentrations in Tompkins County (13 percent) than in the stratified-drift aquifer systems of the northern United States (9 percent) is probably due to confined aquifers that are more prevalent in Tompkins County than in the study by Thomas (2007).

The concentration of aluminum in one unfiltered sample ( $256 \mu \mathrm{g} / \mathrm{L}$, from well TM1018 finished in the bedrock aquifer) exceeded the EPA MCL $50 \mu \mathrm{g} / \mathrm{L}$. Barium concentrations ranged 36.1 to $1,290 \mu \mathrm{g} / \mathrm{L}$, with a median of $189 \mu \mathrm{g} / \mathrm{L}$ (tables 7,9 , and 10). The highest concentration of barium was $1,290 \mu \mathrm{g} / \mathrm{L}$ (table 9), which was detected in an unfiltered sample from TM1018 (Danby Town Hall well). Boron concentrations ranged from 11 to $346 \mu \mathrm{g} / \mathrm{L}$, with a median of $45 \mu \mathrm{g} / \mathrm{L}$ (tables 7, 9, and 10); MCLs have not been established for boron. Cadmium concentrations ranged $<0.018$ to $0.026 \mu \mathrm{g} / \mathrm{L}$, with a median of $<0.02 \mu \mathrm{g} / \mathrm{L}$ (tables 7, 9, and 10). Cadmium concentrations did not exceed the EPA MCL and NYSDOH MCL of $5 \mu \mathrm{g} / \mathrm{L}$. Chromium was detected in three of the nine samples. In samples where chromium was detected; concentrations were low $(<0.05 \mu \mathrm{g} / \mathrm{L})$ and did not exceed the EPA and NYSDOH MCLs of $100 \mu \mathrm{g} / \mathrm{L}$. Cobalt concentrations ranged $<0.020$ to $0.24 \mu \mathrm{g} / \mathrm{L}$, with a median of $0.38 \mu \mathrm{g} / \mathrm{L}$ (tables 7, 9, and 10).

Copper was detected at a concentration above the reporting limit of $1.0 \mu \mathrm{g} / \mathrm{L}$ in only one unfiltered sample (well TM1018, finished in the bedrock aquifer; table 9). Copper was detected at a concentration $180 \mu \mathrm{g} / \mathrm{L}$, which did not exceed the EPA SDWS of $1,000 \mu \mathrm{g} / \mathrm{L}$.

The concentration of iron in three filtered samples and in one unfiltered sample exceeded the NYSDOH MCL and EPA SDWS of $300 \mu \mathrm{g} / \mathrm{L}$. Iron concentrations ranged from $<6.0$ to $1,660 \mu \mathrm{g} / \mathrm{L}$, with a median of $218 \mu \mathrm{g} / \mathrm{L}$ (tables 7, 9, and 10). The concentration of manganese in seven filtered samples exceeded the EPA SDWS of $50 \mu \mathrm{g} / \mathrm{L}$; the concentration of manganese in two filtered samples exceeded the NYSDOH $\mathrm{MCL}$ of $300 \mu \mathrm{g} / \mathrm{L}$. Manganese concentrations ranged from 1.20 to $421 \mu \mathrm{g} / \mathrm{L}$, with a median of $105 \mu \mathrm{g} / \mathrm{L}$ (tables 7, 9, and 10).

Lead was detected in four out of nine samples, but none exceeded EPA MCL of $15 \mu \mathrm{g} / \mathrm{L}$. Lead concentrations ranged from $<0.06$ to $1.48 \mu \mathrm{g} / \mathrm{L}$, with a median of $<0.06 \mu \mathrm{g} / \mathrm{L}$ (tables 7, 9, and 10). Lithium concentrations ranged from 
2.40 to $155 \mu \mathrm{g} / \mathrm{L}$, with a median of $6.21 \mu \mathrm{g} / \mathrm{L}$ (tables 7,9 , and 10)_drinking-water standards have not been established for lithium.

Molybdenum concentrations ranged from 0.12 to $7.39 \mu \mathrm{g} / \mathrm{L}$, with a median of $1.97 \mu \mathrm{g} / \mathrm{L}$ (tables 7,9 , and 10). Nickel concentrations ranged from 0.19 to $1.1 \mu \mathrm{g} / \mathrm{L}$, with a median of $0.39 \mu \mathrm{g} / \mathrm{L}$ (tables 7,9 , and 10). Strontium concentrations ranged from 53.9 to $1,430 \mu \mathrm{g} / \mathrm{L}$, with a median of $290 \mu \mathrm{g} / \mathrm{L}$ (tables 7, 9, and 10). Drinking-water standards have not been established for molybdenum, nickel, and strontium.

Selenium concentrations ranged from $<0.06$ to $0.07 \mu \mathrm{g} / \mathrm{L}$, with a median of $<0.06 \mu \mathrm{g} / \mathrm{L}$ (tables 7,9 , and 10). Uranium concentrations ranged from 0.009 to $1.47 \mu \mathrm{g} / \mathrm{L}$, with a median of $0.159 \mu \mathrm{g} / \mathrm{L}$. Zinc concentrations ranged from $<1.8$ to $24.1 \mu \mathrm{g} / \mathrm{L}$, with a median of $<2.0 \mu \mathrm{g} / \mathrm{L}$ (tables 7,9 , and 10 ); the concentrations of selenium, uranium, and zinc did not exceed any Federal or State drinking-water standards.

\section{Dissolved Gases}

Methane, nitrogen, argon, carbon dioxide, and dissolved oxygen concentrations were determined at four sites where baseline samples for hydraulic fracturing for unconventional development of wells drilled for natural gas were collected (table 10). Methane was detected at low concentrations $(0.005 \mathrm{mg} / \mathrm{L}$ or less) in 3 of the 4 samples; the concentration in the fourth sample (TM2519; finished in the bedrock aquifer) was $9.54 \mathrm{mg} / \mathrm{L}$, which is slightly lower than the concentration that the Office of Surface Mining recommends that methane concentrations be closely monitored (Eltschlager and others, 2001). Although the EPA and NYSDOH do not have MCLs for methane, dissolved methane concentrations greater than $28 \mathrm{mg} / \mathrm{L}$ can pose explosion hazards as a result of methane accumulation in confined spaces (Eltschlager and others, 2001). Nitrogen, argon, and carbon dioxide gases ranged in concentration from 19.7 to $27.6,0.745$ to 0.919 , and 3.65 to $20.5 \mathrm{mg} / \mathrm{L}$, respectively (table 10 ). Dissolved oxygen was determined at 12 sites and concentrations ranged from 0.1 to $2.8 \mathrm{mg} / \mathrm{L}$, with a median value of $0.4 \mathrm{mg} / \mathrm{L}$ (tables 6, 8, and 10).

\section{Comparison to Other Stratified-Drift Aquifers in Tompkins County}

The major-ion compositions of water from sampled wells from this study area and from three other stratified-drift aquifer systems in Tompkins County (lower Sixmile Creek and Willseyville Creek trough (Miller and Karig, 2010), upper Sixmile Creek and West Branch Owego Creek valleys (Miller and Sherwood, 2009), and Virgil Creek and Dryden Lake valleys (Miller and Bugliosi, 2013); fig. 1) are presented for comparison using a Piper (trilinear) diagram (fig. 20). A Piper diagram (Piper, 1944) shows the relative proportion of major cations and anions, on a charge-equivalent basis, to the total ion content of the water. Each major ion, in percent of milliequivalents per liter, is shown along the sides of the diagram. Cations are shown in the left triangle and anions are shown in the right triangle. The points are extended into the central diamond-shaped field. The intersection of the projections represents the composition of the water with respect to the combination of ions.

In all stratified-drift aquifers, the cation composition is dominated by calcium and, in a few cases by sodium (fig. 20). The anion composition is dominated by bicarbonate and, in a few samples, by chloride. Results of the groundwater sample analyses for this study indicate that the groundwater in the stratified-drift aquifers in the upper Buttermilk Creek and Danby Creek valleys is dominated by calcium bicarbonate ions. The exceptions are two samples that were collected in upper Buttermilk Creek and Danby Creek valleys and two samples in upper Sixmile Creek and West Branch Owego Creek valleys, which had ions that were sodium bicarbonate (fig. 20). These four samples with sodium bicarbonate to sodium chloride type waters are attributed to enrichment from brackish water in bedrock that locally discharges to the valley fill (Miller, 2009) or to road-salt contamination. Water chemistry in stratified-drift aquifers in all four study areas is similar because the geologic settings of all four areas are similar and are composed of Valley Heads glacial drift and Devonian shales and siltstones.

\section{Summary}

In 2006, the U.S. Geological Survey, in cooperation with the Town of Danby and Tompkins County Planning Department, began a study of the stratified-drift aquifer system in the upper Buttermilk Creek and Danby Creek valleys in the Town of Danby, Tompkins County, New York. In the northern part of upper Buttermilk Creek valley, there is only one stratified-drift aquifer - a basal confined. In the southern part of upper Buttermilk Creek valley, near the Hamlet of Danby, there are as many as four stratified-drift aquifers - two are unconfined and two are confined. In the south-draining Danby Creek valley, an unconfined aquifer consists of outwash and kame sand and gravel — deposited by glacial meltwaters during the late Pleistocene Epoch and of alluvial sediments that were deposited by streams during the Holocene Epoch (post-glacial period).

The principal sources of recharge to the unconfined aquifers in the study area include direct infiltration of precipitation (rain and snowmelt) at land surface, unchanneled surface runoff from adjacent hillsides that seeps into the aquifer along the edges of the valley, groundwater inflow from till and bedrock that enters the aquifer along the sides of the valley, seepage loss from upland-tributary streams where they flow over alluvial fans in the valley, and upward leakage from the underlying geologic units in the valley where the hydraulic head in these units are higher than the water table in the 


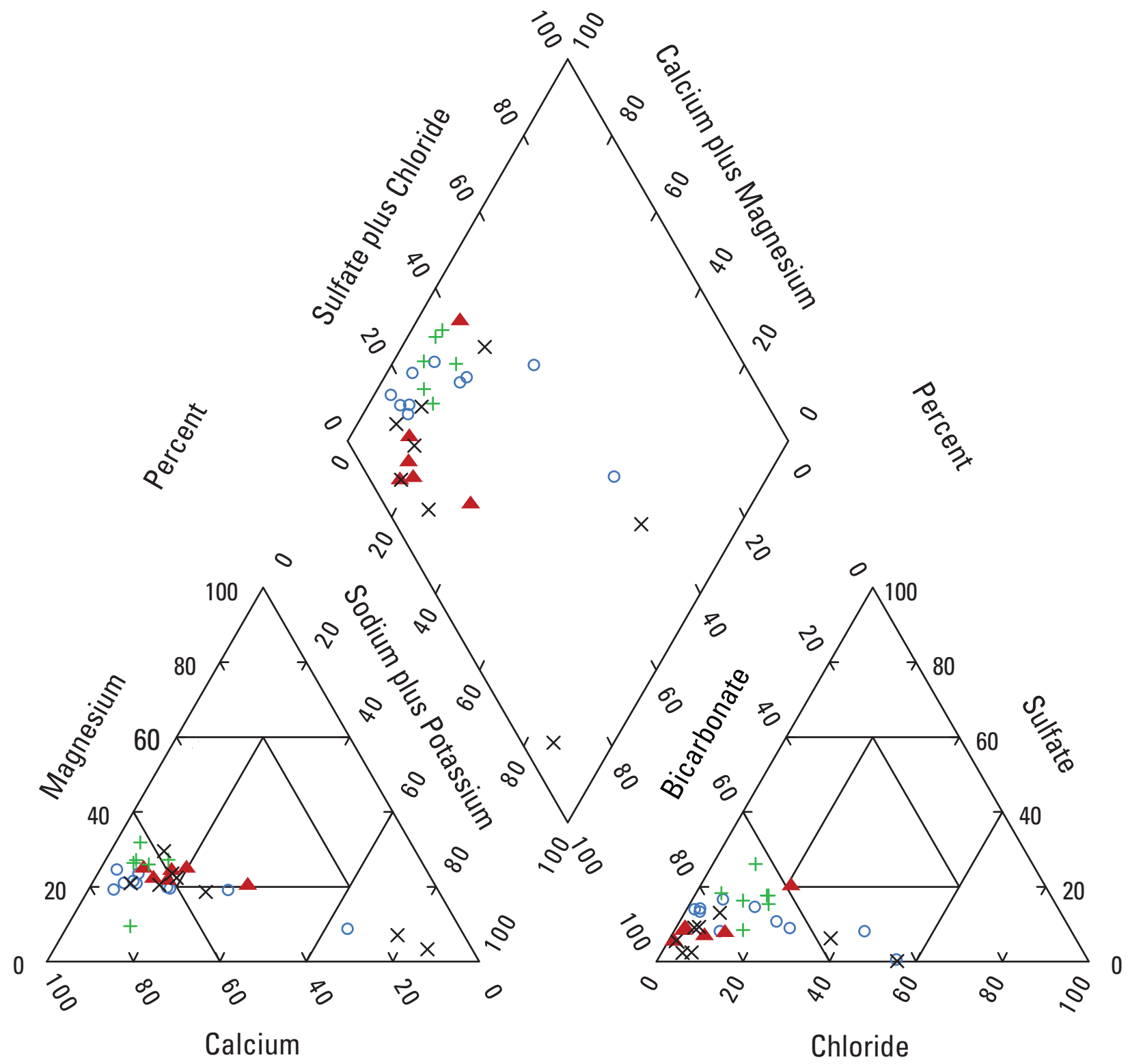

Percent

\section{EXPLANATION}

$\times \quad$ Upper Buttermilk Creek and Danby Creek Valleys groundwater sample

+ Virgil Creek and Dryden Lake Valleys groundwater sample

- Lower Sixmile Creek and Willseyville Creek trough groundwater sample

- Upper Sixmile Creek and West Branch Owego Creek Valleys groundwater sample

Figure 20. Variability in major ion composition of groundwater in upper Buttermilk Creek and Danby Creek valleys, Virgil Creek and Dryden Lake valleys, Lower Sixmile Creek and Willseyville Creek trough, and upper Sixmile Creek and West Branch Owego Creek valleys, Tompkins County, New York. 
unconfined aquifer. The percentages of all sources of recharge to the contiguous unconfined aquifer in Danby Creek valley are 16 percent from precipitation that falls directly over the aquifer, 55 percent from runoff and groundwater inflow from adjacent unchanneled hillsides, and 29 percent from losing streams that cross the aquifer. The total annual recharge to the contiguous unconfined aquifer is 2.56 cubic feet per second (604 million gallons per year).

The principal sources of recharge to the confined aquifers include precipitation that falls directly on the surficial confining unit, which then slowly flows vertically downward through the fine-grained sediments and enters the confined aquifer, and groundwater inflow from till and bedrock that borders the aquifer along adjacent hillsides and at the bottom of the valley. In addition, there is substantial amounts of recharge to the confined aquifers where the confining units are locally absent (forming windows) and where parts of the confining units consist of sediments of low to moderate permeability (forming a semiconfining layer).

Confined aquifers can be under a high degree of confinement; where this condition is present, the confined aquifers, are isolated from sources of recharge by thick, extensive, and low permeability confining units that impede seepage of water, and, therefore, receive small amounts of recharge. However, where the confined aquifer is under a low-to-moderate degree of confinement (semiconfined) or where the confining unit is locally absent, the confined aquifer receives moderate amounts of recharge from precipitation that falls directly over the windows in the confining unit or on the semi-permeable confining unit, which then slowly flows vertically downward and enters the confined aquifer.

In the northern part of the study area (upper Buttermilk Creek valley), groundwater in the stratified drift discharges to domestic and commercial wells, Buttermilk Creek in the area near the northern town border, and a small unnamed stream in a ravine in Buttermilk State Park just north of the town border. In the southern part of the study area (Danby Creek valley), groundwater discharges to domestic, commercial, and farm wells; to Danby Creek; to a large wetland in the central parts of Danby Creek valley; and as losses because of plant uptake and evaporation. About 300 people depend on groundwater from the Buttermilk Creek and Danby Creek stratified-drift aquifer system.

An unconfined surficial aquifer about 8,000 feet (ft) long and as much as $800 \mathrm{ft}$ wide, with a saturated thickness of about $20 \mathrm{ft}$, occupies the lower (southeastern most) $8,000 \mathrm{ft}$ of Danby Creek valley within the Town of Danby. The average annual recharge to the contiguous unconfined aquifer is 2.56 cubic feet per second (1.66 million gallons per day). However, because the volume of water stored in the aquifer is small and the potential for induced recharge from Danby Creek during summer periods of low flow is also small, an array of wells would probably be needed to provide a sustainable continuous amount of water to large water users such as municipalities and industries.
Well data from water-well drillers through 2012 indicate that the confined aquifers in upper Buttermilk Creek valley are thin (typically about $10 \mathrm{ft}$ thick) and the reported well-yield data ranged from 3 to 50 gallons per minute. These well yield data suggest that the aquifer meets the needs of homeowners and small commercial facilities, but these aquifers may not be capable of supplying sufficient water to meet the needs of municipalities and industries. Additional geohydrologic data leading to calibration of a groundwater flow model would be required to evaluate the long-term potential yield from the confined aquifers in upper Buttermilk Creek valley.

During 2007-10, groundwater samples were collected from 13 wells that tap the stratified-drift and bedrock aquifers - seven samples were from the confined stratifieddrift aquifers, one from an unconfined stratified-drift aquifer, and five were from bedrock aquifers. The samples were collected and processed using standard U.S. Geological Survey procedures and were analyzed for physiochemical properties and chemical constituents, including dissolved gases, major ions, nutrients, and trace elements. Calcium dominates the cation composition and bicarbonate dominates the anion composition in most groundwater. Water quality in the study area generally meets Federal and New York State drinking-water standards, but concentrations of some constituents exceeded the standards. The standards that were exceeded were sodium ( 3 samples), dissolved solids (1 sample), iron ( 3 samples), manganese ( 8 samples), and arsenic (1 sample).

\section{References Cited}

Cadwell, D.L., and Muller, E.H., 2004, New York Glacial Geology in Ehlers, J., and Gibbard, P.L., eds., Quaternary Glaciations-Extent and Chronology, Part II, North America Developments in Quaternary Science: Elsevier, Amsterdam, v. 2b.

Cressey, G.B., 1966, Land forms in Thompson, J.H., ed., Geography of New York State: Syracuse, N.Y., Syracuse University Press, p. 26.

Eltschlager, K.K., Hawkins, J.W., Ehler, W.C., and Baldassare, Fred, 2001, Technical measures for the investigation and mitigation of fugitive methane hazards in areas of coal mining: U.S. Department of the Interior, Office of Surface Mining Reclamation and Enforcement, 125 p. [Also available at http://www.techtransfer.osmre.gov/NTTMainSite/Library/ hbmanual/methane/methane.pdf.]

Fisher, D.W., Isachsen, Y.W., and Rickard, L.V., 1970, Geologic map of New York State-Finger Lakes Sheet: New York State Museum Map and Chart Series no. 15, 1 sheet, scale 1:250,000. 
Fullerton, D.S., 1980, Preliminary correlation of post-Erie interstadial events $(16,000-10,000$ radiocarbon years before present), central and eastern Great Lakes region, and Hudson, Champlain, and St. Lawrence lowlands, United States and Canada: U.S. Geological Survey Professional Paper $1089,52 \mathrm{p}$.

Haeni, F.P., 1988, Application of seismic-refraction techniques to hydrologic studies: U.S. Geological Survey Techniques of Water-Resources Investigations, book 2, chap. D2, 86 p.

Heath, R.C., 1976, Design of ground-water level observation programs: Ground Water, v. 14, no. 2. p. 71-77.

Hem, J.D., 1985, Study and interpretation of the chemical characteristics of natural water ( $3 \mathrm{~d}$ ed.): U.S. Geological Survey Water-Supply Paper 2254, 264 p.

Hutson, S.S., Barber, N.L., Kenny, J.F., Linsey, K.S., Lumia, D.S., Maupin, M.A., 2000, Estimated use of water in the United States in 2000: U.S. Geological Survey Circular $1268,52 \mathrm{p}$.

Isachsen, Y.W., Landing, E., Lauber, J.M., Rickard, L.V., and Rogers, W.B., eds, 1991, Geology of New York-A simplified account: New York State Museum Educational Leaflet no. 28,284 p.

Kappel, W.M., and Miller, T.S., 2003, Hydrogeology of the Tully trough - Southern Onondaga County and Northern Cortland County, New York: U.S. Geological Survey WaterResources Investigations Report 03-4112, 16 p.

Karig, D.E., and Elkins, L.T., 1986, Geologic summary of the Cayuga Lake region: in New York State Geological Association Field Trip Guidebook, 58th annual meeting, p. 1-21.

Kenney, T.A., 2010, Levels at gaging stations: U.S. Geological Survey Techniques and Methods, book 3, chap. A39, 60 p.

Kontis, A.L., Randall, A.D., and Mazzaferro, D.L., 2004, Regional hydrology and simulation of flow of stratified-drift aquifers in the glaciated northeastern United States: U.S. Geological Survey Professional Paper 1415-C, 156 p.

Ku, H.F.H., Randall, A.D., and MacNish, R.D., 1975, Streamflow in the New York part of the Susquehanna River Basin: New York State Department of Environmental Conservation Bulletin 71, $130 \mathrm{p}$.

Lane, J.W., Jr., White, E.A., Steele, G.V., and Cannia, J.C., 2008, Estimation of bedrock depth using the horizontal-tovertical (H/V) ambient-noise seismic method, in Symposium on the Application of Geophysics to Engineering and Environmental Problems, April 6-10, 2008, Philadelphia, Pennsylvania, Proceedings: Denver, Colo., Environmental and Engineering Geophysical Society, 13 p.
Mechenich, Christine and Andrews, Elaine, 2004, Home water safety-Interpreting drinking water test results: Cooperative Extension Publishing, University of Wisconsin, Extension Bulletin G3558-4, 12 p.

Miller, T.S., 2000, Unconsolidated aquifers in Tompkins County, New York: U.S. Geological Survey WaterResources Investigation Report 00-4211, 1 plate, scale $1: 24,000$.

Miller, T.S., 2009, Geohydrology and water quality of the valley-fill aquifer system in the upper Sixmile Creek and West Branch Owego Creek valleys in the Town of Caroline, Tompkins County, New York: U.S. Geological Survey Scientific Investigations Report 2009-5173, 56 p.

Miller, T.S., and Bugliosi, E.F., 2013, Geohydrology, water quality, and simulation of groundwater flow in the stratified-drift aquifer system in Virgil Creek and Dryden Lake valleys, Town of Dryden, Tompkins County, New York: U.S. Geological Survey Scientific Investigations Report 2013-5070, 104 p. [Also available at http://pubs.usgs.gov/ sir/2013/5070/.]

Miller, T.S., Bugliosi, E.F., and Reddy, J.E., 2008, Geohydrology of the unconsolidated valley-fill aquifer in the Meads Creek valley, Schuyler and Steuben Counties, New York: U.S. Geological Survey Scientific Investigations Report 2008-5122, 32 p. [Also available at http://pubs.usgs.gov/ sir/2008/5122.]

Miller, T.S., and Karig, D.E., 2010, Geohydrology of the stratified-drift aquifer system in the lower Sixmile Creek and Willseyville Creek trough, Tompkins County, New York: U.S. Geological Survey Scientific Investigations Report 2010-5230, 54 p.

Miller, T.S., and Pittman, L.S., 2012, Hydrogeology of the stratified-drift aquifers in the Cayuta Creek and Catatonk Creek valleys in parts of Tompkins, Schuyler, Chemung, and Tioga Counties, New York: U.S. Geological Survey Scientific Investigations Report 2012-5127, 50 p.

Miller, T.S., Sherwood, D.A., Jeffers, P.M., and Mueller, Nancy, 1998, Hydrogeology, water quality, and simulation of ground-water flow in a glacial-aquifer system, Cortland County, New York: U.S. Geological Survey WaterResources Investigations Report 96-4255, 84 p., 5 plates, scale $1: 24,000$.

Muller, E.H., and Cadwell, D.H., 1986, Surficial geologic map of New York, Finger Lakes Sheet: New York State Museum, Geological survey Map and Chart Series no. 40, scale 1:250,000.

Muller, E.H., and Calkin, P.E., 1993, Timing of Pleistocene glacial events in New York State: Canadian Journal of Earth Sciences, v. 30, p. 1829-1845. 
Murphy, P.J., 1981, Detachment structures in south-central New York: Northeastern Geology, 1981, v. 3, no. 2, p. 105-115.

Neeley, J.A., 1961, Soil survey of Tomkins County, New York: U. S. Department of Agriculture in cooperation with Cornell University Agricultural Experiment Station, Series 1961, no. $25,241 \mathrm{p}$.

New York State Department of Health, 2011, New York State Health Department public water systems regulations: Albany, N.Y., New York State Department of Health, [variously paged], accessed January 2012 at http://www.health. state.ny.us/environmental/water/drinking/part5/tables.htm.

Northeast Regional Climate Center, 2012, Ithaca climate page: accessed November, 13, 2012, at http://www.nrcc.cornell. edu/climate/ithaca/.

Piper, A.M., 1944, A graphic procedure in the geochemical interpretation of water analyses: American Geophysical Union Transactions, v. 25, p. 914-923.

Podwysocki, M.H., Pohn, H.A., Phillips, J.D., Krohn, M.D., Purdy, T.L., and Merin, I.S., 1982, Evaluation of remote sensing, geological, and geophysical data for south-central New York and northern Pennsylvania: U.S. Geological Survey Open-File Report 82-319, 176 p.

Randall, A.D., 1978, Infiltration from tributary streams in the Susquehanna River basin: U.S. Geological Survey Journal of Research, v. 6, no. 3, p. 285-297.

Rantz, S.E., and others, 1982, Measurement and computation of streamflow Volume 1-Measurement of stage and discharge: U.S. Geological Survey Water-Supply Paper 2175, $284 \mathrm{p}$.

Rickard, L.V., Isachsen, Y.W., and Fisher, D.W., 1970, Geologic map of New York_-Finger Lakes sheet: New York state Museum Map and Chart Series no. 15, scale $1: 250,000$.

Scott, J.H., Tibbetts, B.L., and Burdick, R.G., 1972, Computer analysis of seismic refraction data: U.S. Bureau of Mines Report of Investigation 7595, 95 p.
Thomas, M.A., 2007, The association of arsenic with redox conditions, depth, and ground-water age in the glacial aquifer system of the Northern United States: U.S. Geological Survey Scientific Investigations Report 2007-5036, 26 p.

Tompkins County Water Resources Council, 2014, Arsenic in your well water: Tompkins County Planning Department, Fact sheet 2014-01, v.1, issue 1. [Also available at http:// www.tompkins-co.org/planning/committees/WRC/index. htm]

U.S. Census Bureau, 2012, Population and Housing Unit Counts-2010 Census of population and housing, New York, 2010: accessed August 2015 at http://www.census.gov/prod/ cen $2010 /$.

U.S. Environmental Protection Agency, 2009, National primary drinking water standards and national secondary drinking water standards: Washington, D.C., U.S. Environmental Protection Agency, Office of Water, EPA 816-F-090004, 6 p., accessed March 25, 2009, at http://www.epa. gov/safewater/consumer/pdf/mcl.pdf.

U.S. Geological Survey, variously dated, National field manual for the collection of water-quality data: U.S. Geological Survey Techniques of Water-Resources Investigations, book 9, chaps. A1-A9. [Also available at http://pubs.er.usgs.gov/ publication/twri09.]

U.S. Geological Survey Geologic Names Committee, 2010, Divisions of geologic time-major chronostratigraphic and geochronologic units: U.S. Geological Survey Fact Sheet 2010-3059, 2 p.

Williams, H.S., Tarr, R.S., and Kindle, E.M., 1909, Watkins Glen-Catatonk, New York: Geologic Atlas of the United States, Folio 169, 242 p.

Zambito IV, J.J., Baird, G.C., Brett, C.E., and Bartholomew, A.J., 2007, Re-examination of the type Ithaca FormationCorrelations with sections in western New York in New York State Geological Association Field Trip Guidebook: New York State Geological Association, p. 86-105. 



\section{Appendix 1. Records of Wells, Town of Danby, Tompkins}

County, New York 


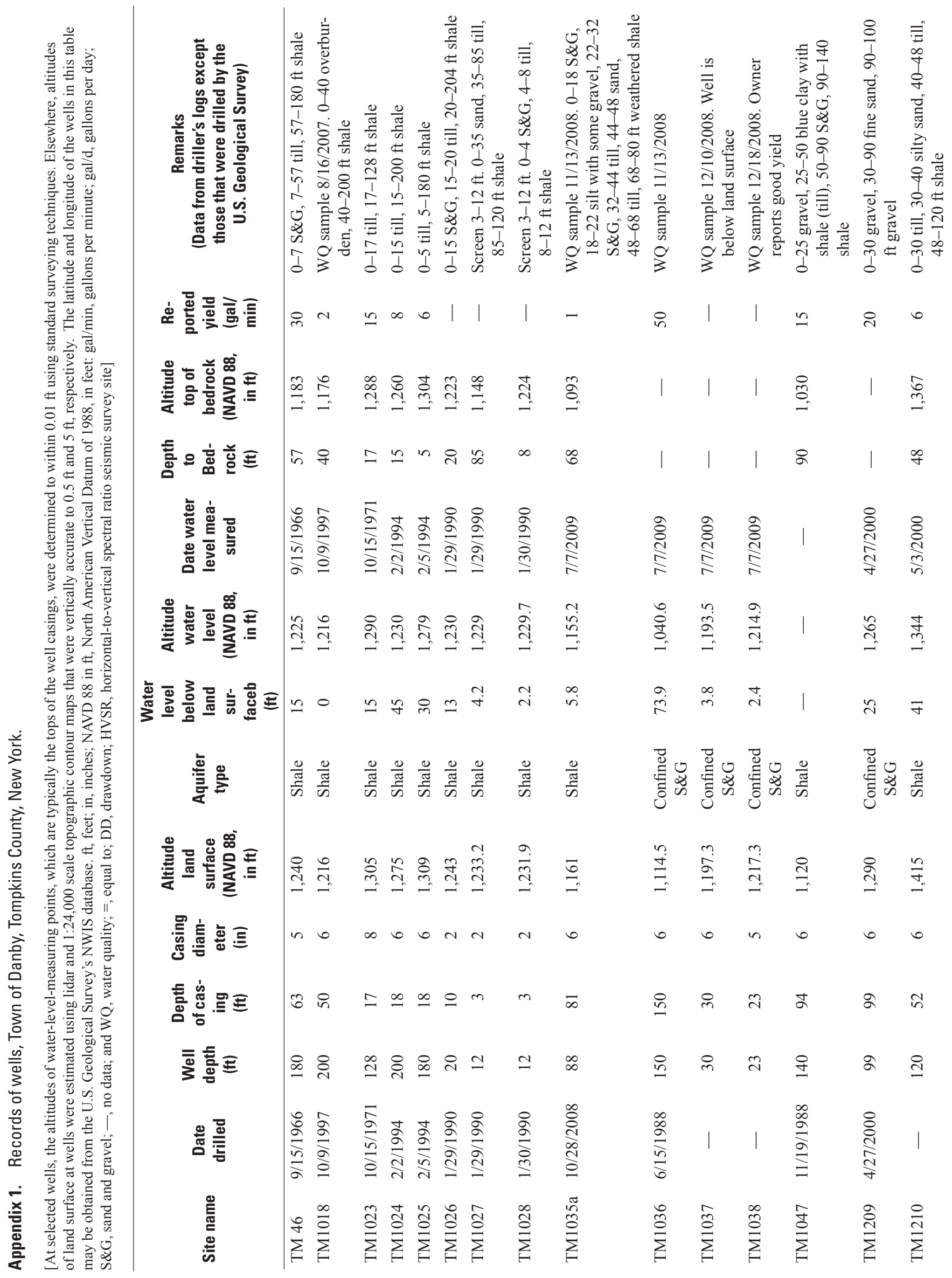




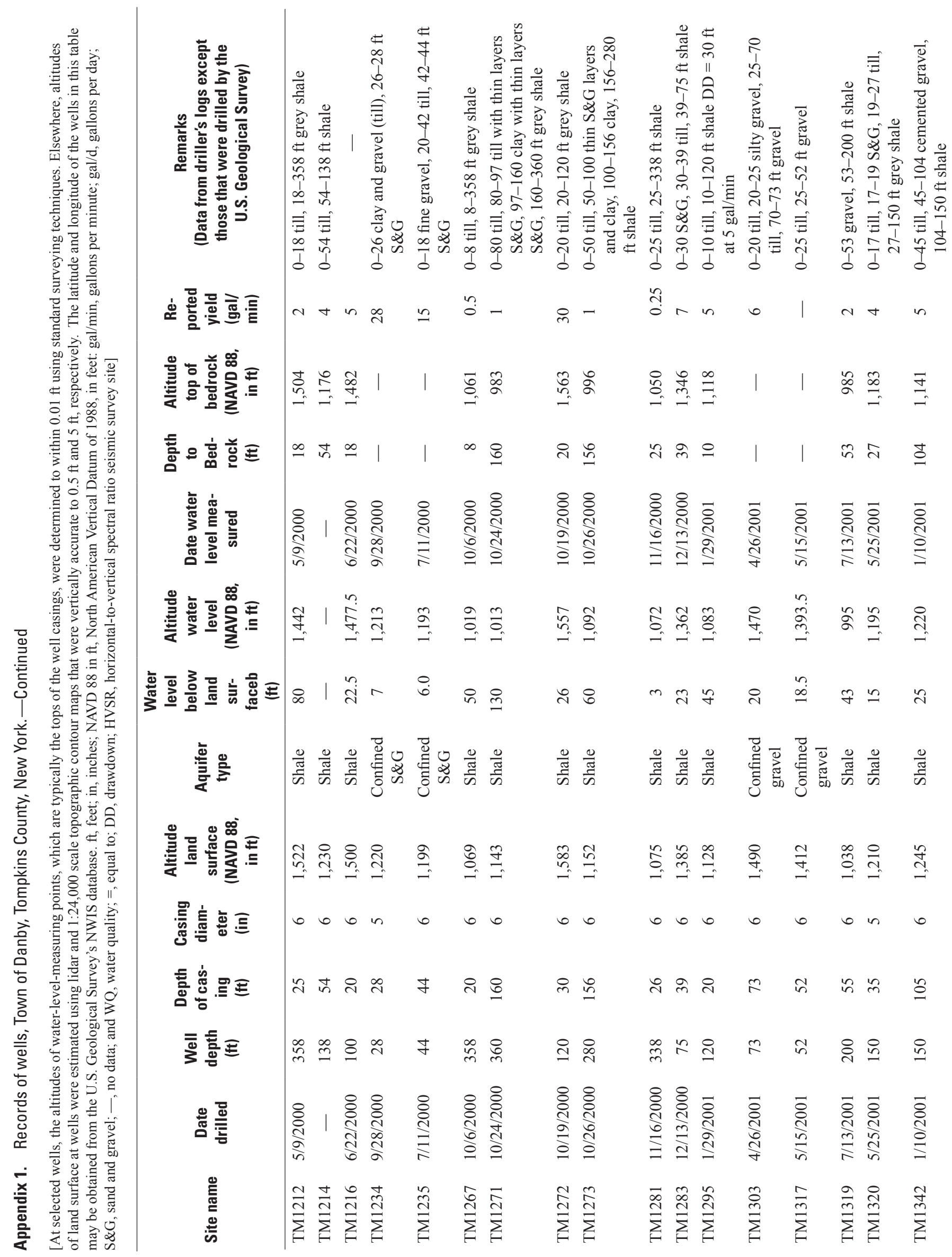




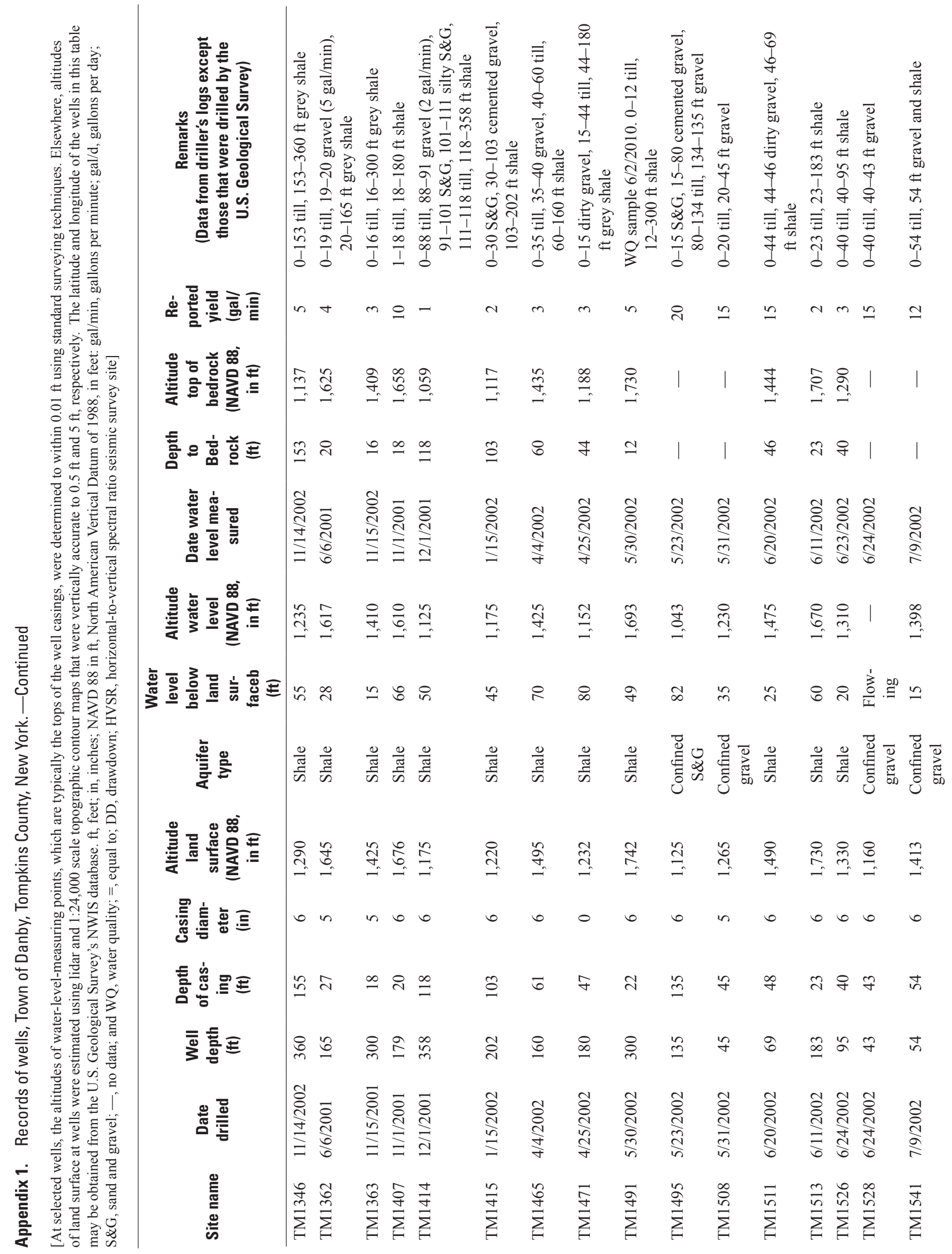




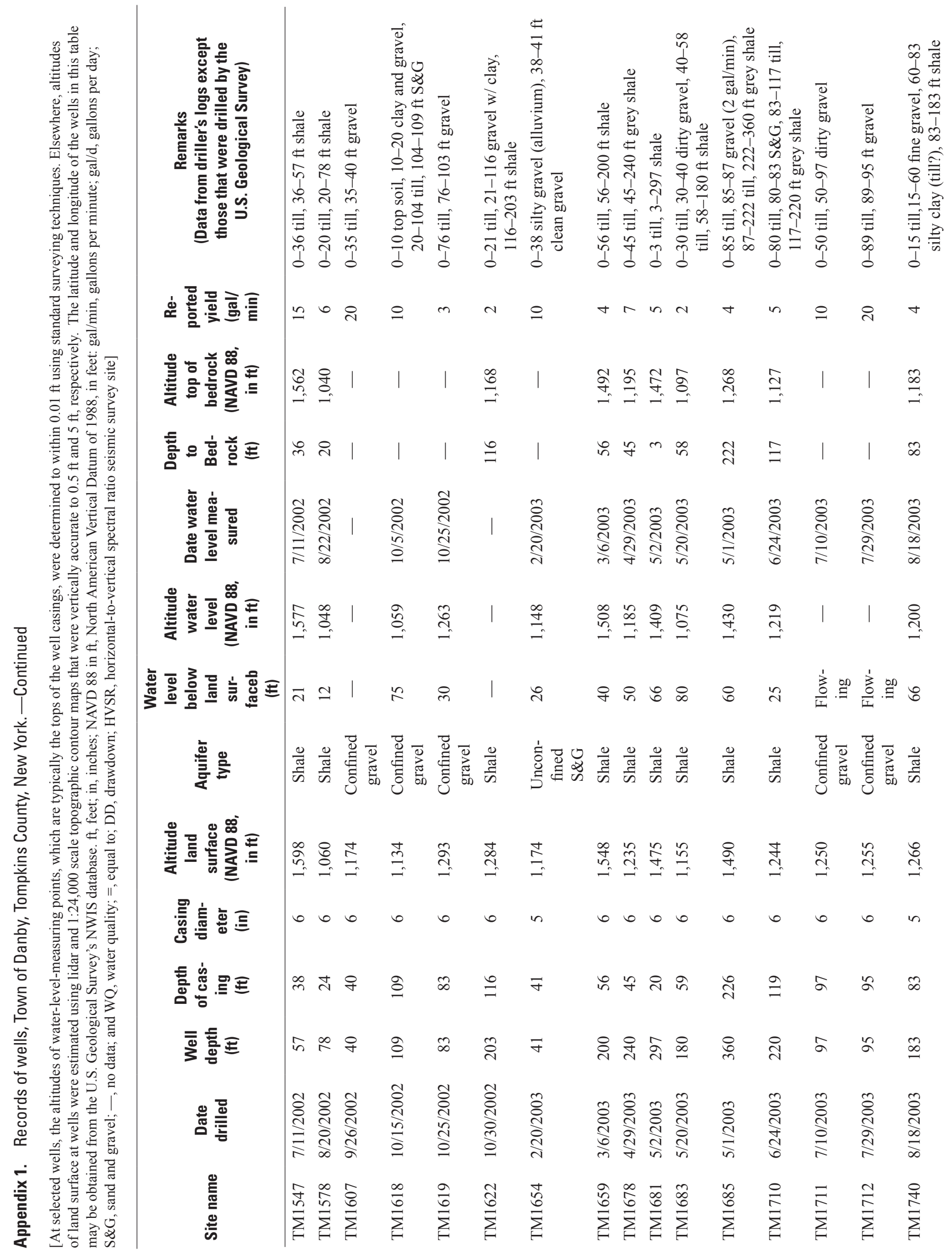




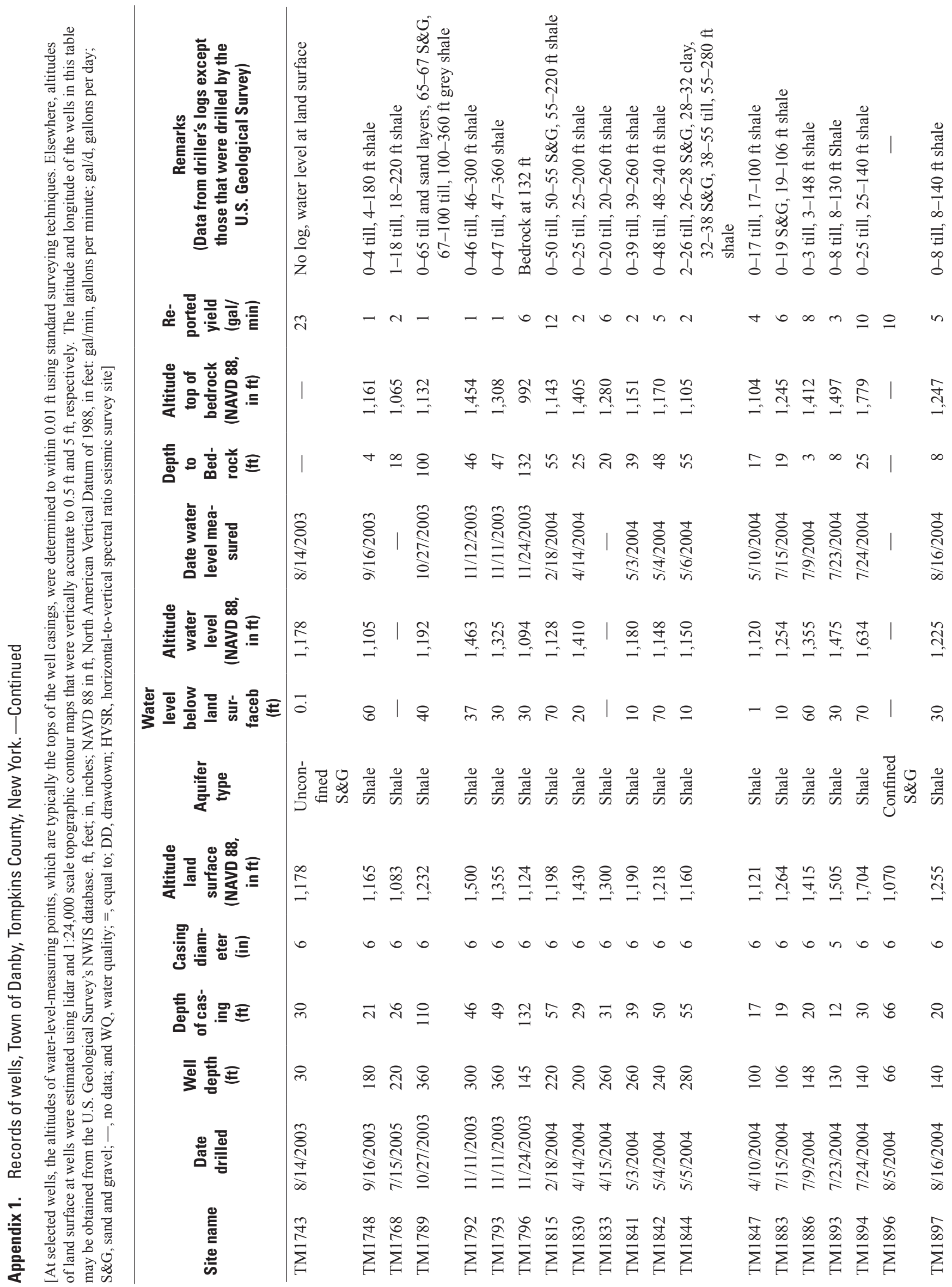




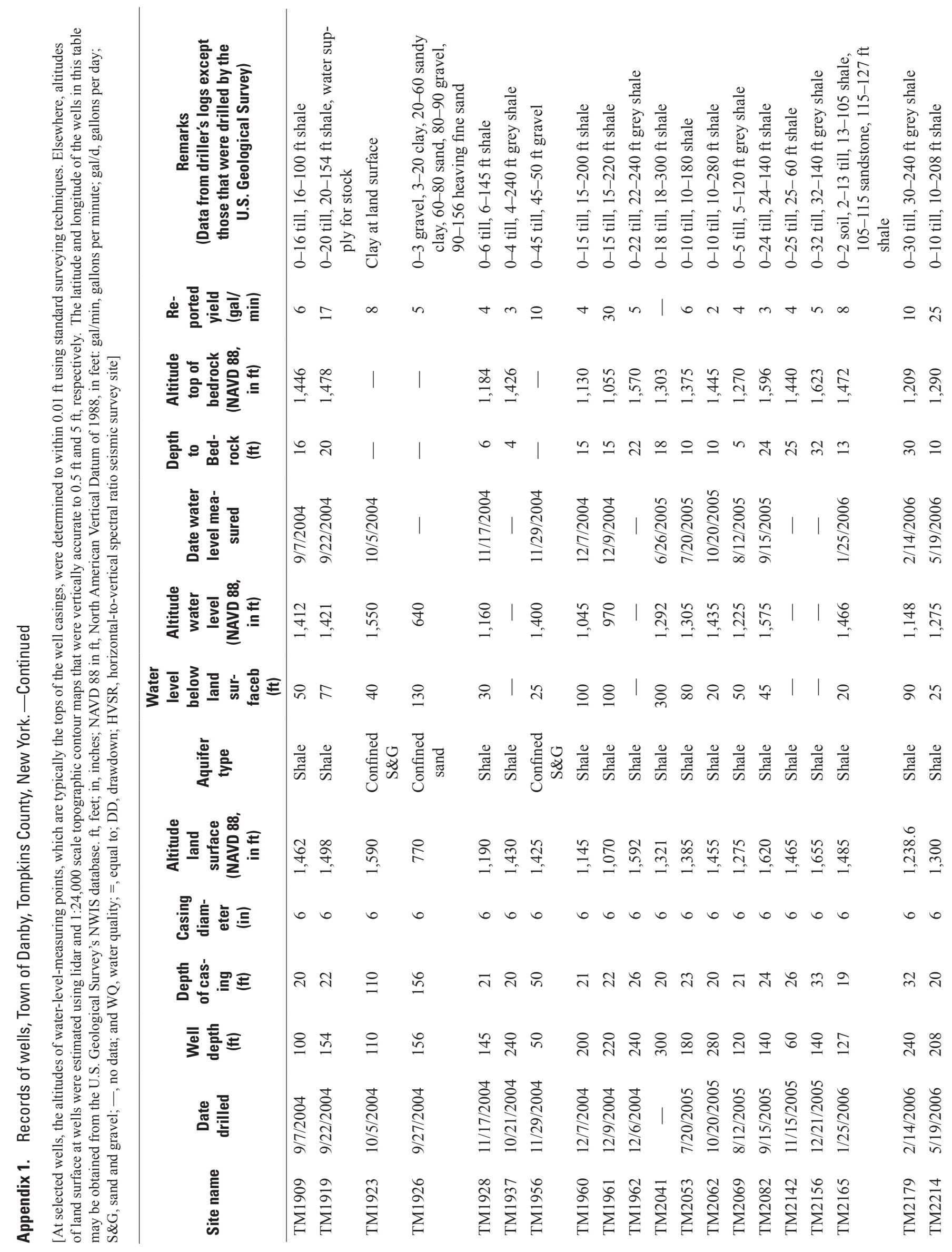




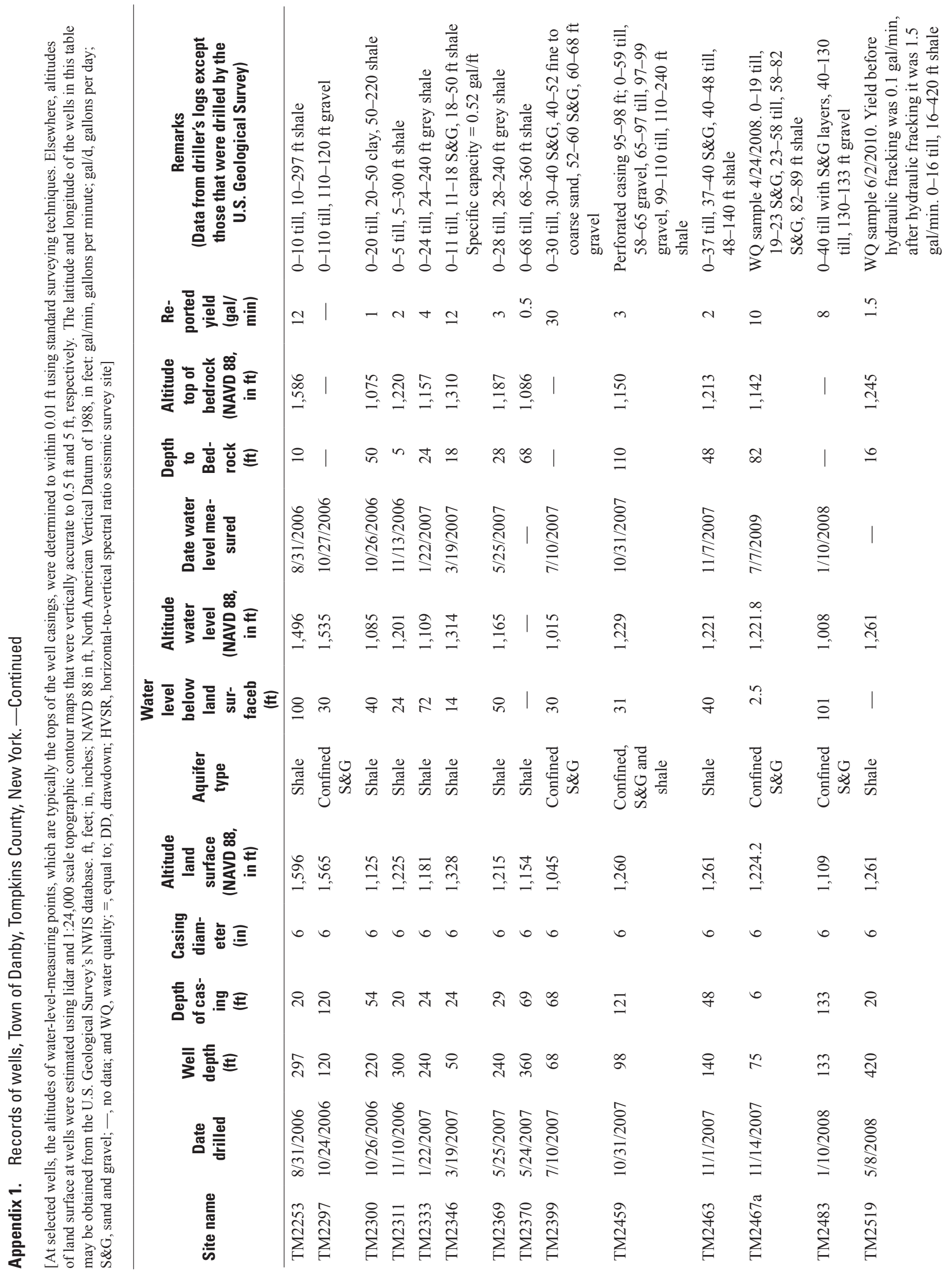




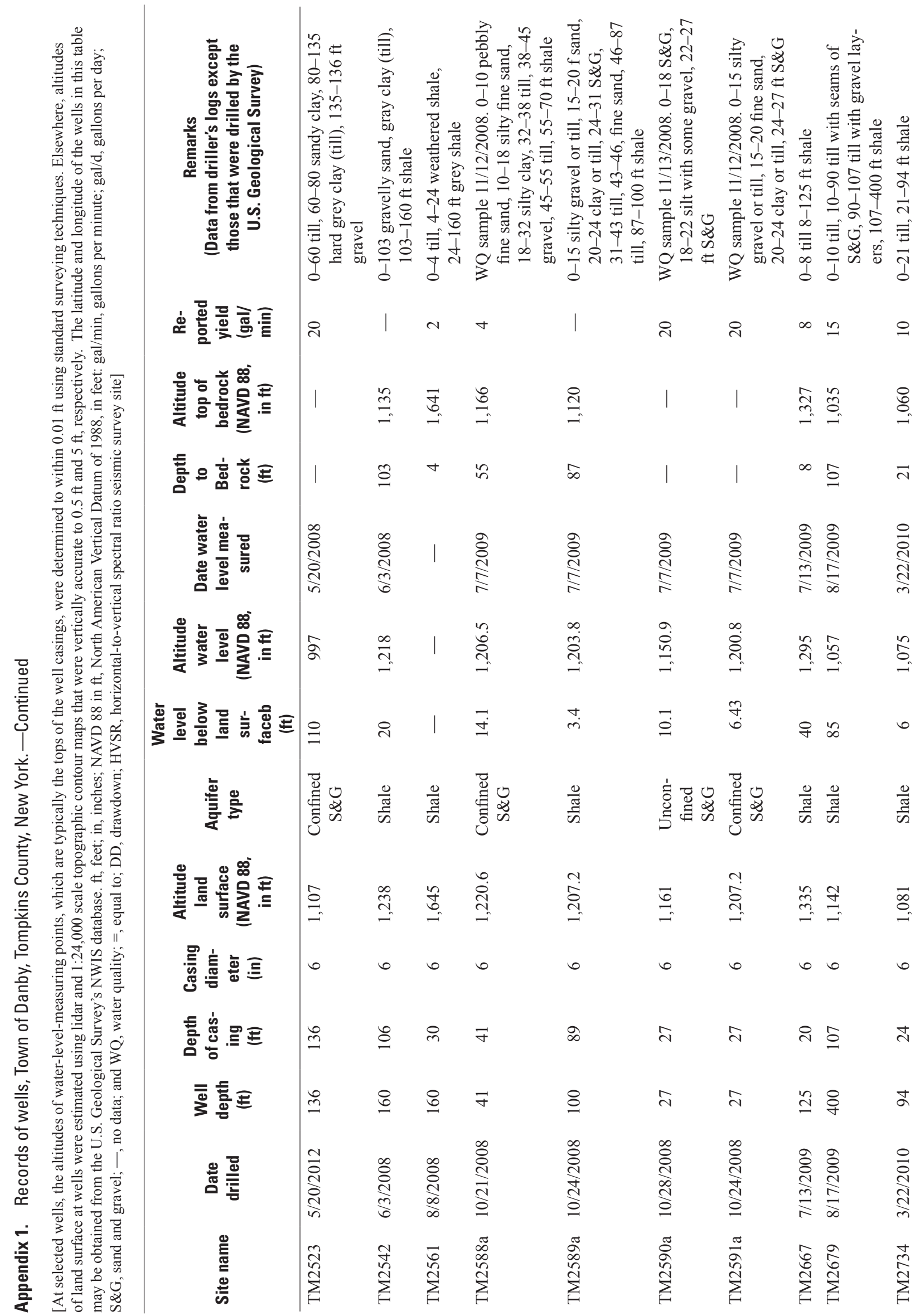




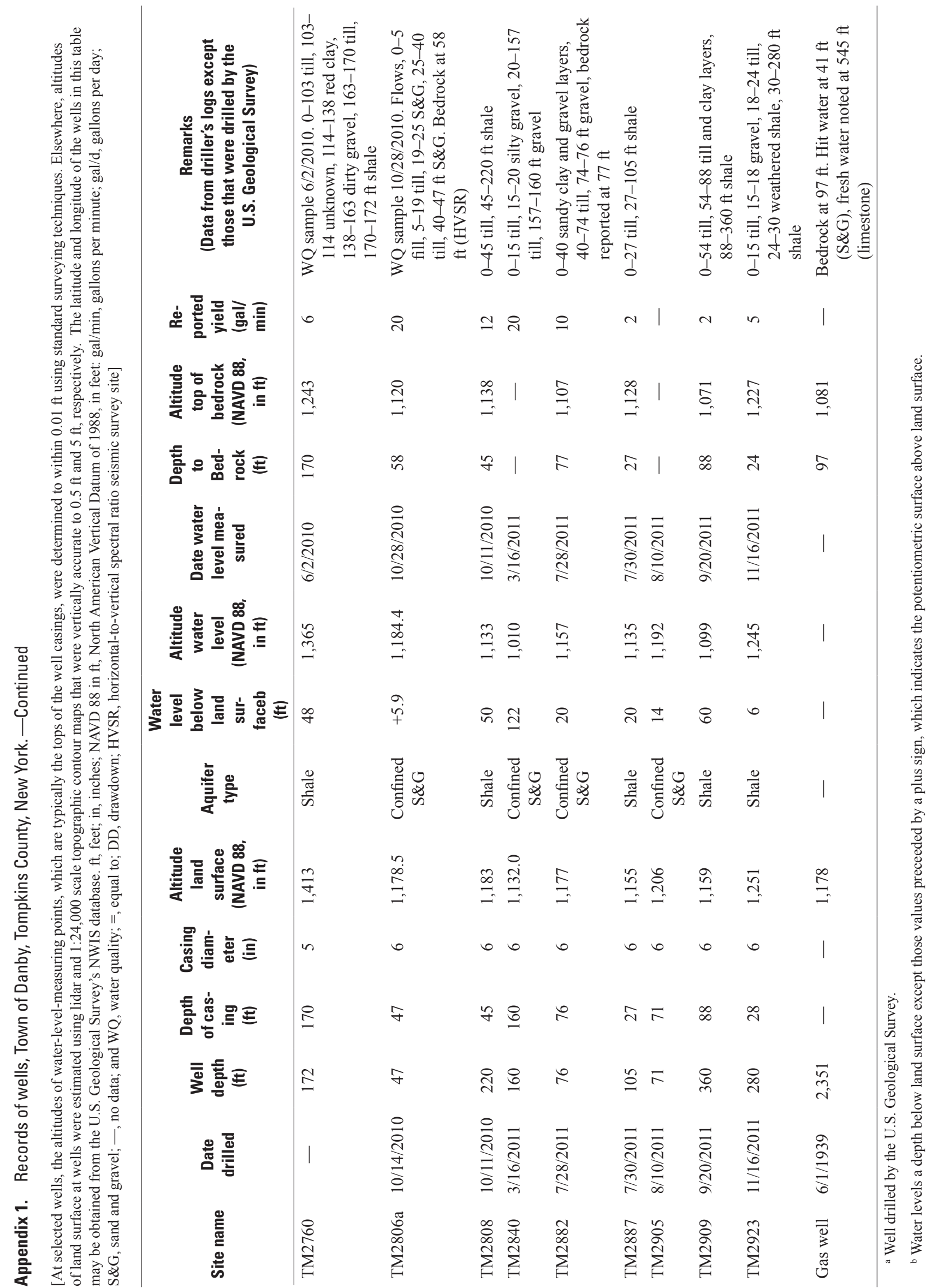


Appendix 2. Well Logs and Construction Details of U.S. Geological Survey Test Wells 


\section{USGS TEST WELL TM2588}

Danby Park Association, Town of Danby, N.Y.

Site name: TM2588 (well depth $=41 \mathrm{ft})$

Site ID: 422116076284701

Latitude: $42^{\circ} 21^{\prime} 15.54^{\prime \prime}$

Longitude: $076^{\circ} 28^{\prime} 46.62^{\prime \prime}$
Date completed: 10/21/2008

Drilling contractor: Barber \& DeLine, Tully, NY

6 inch diameter steel casing

Casing above ground $=2.9 \mathrm{ft}$

Latitude and longitude measurement made by GPS (NAD83)

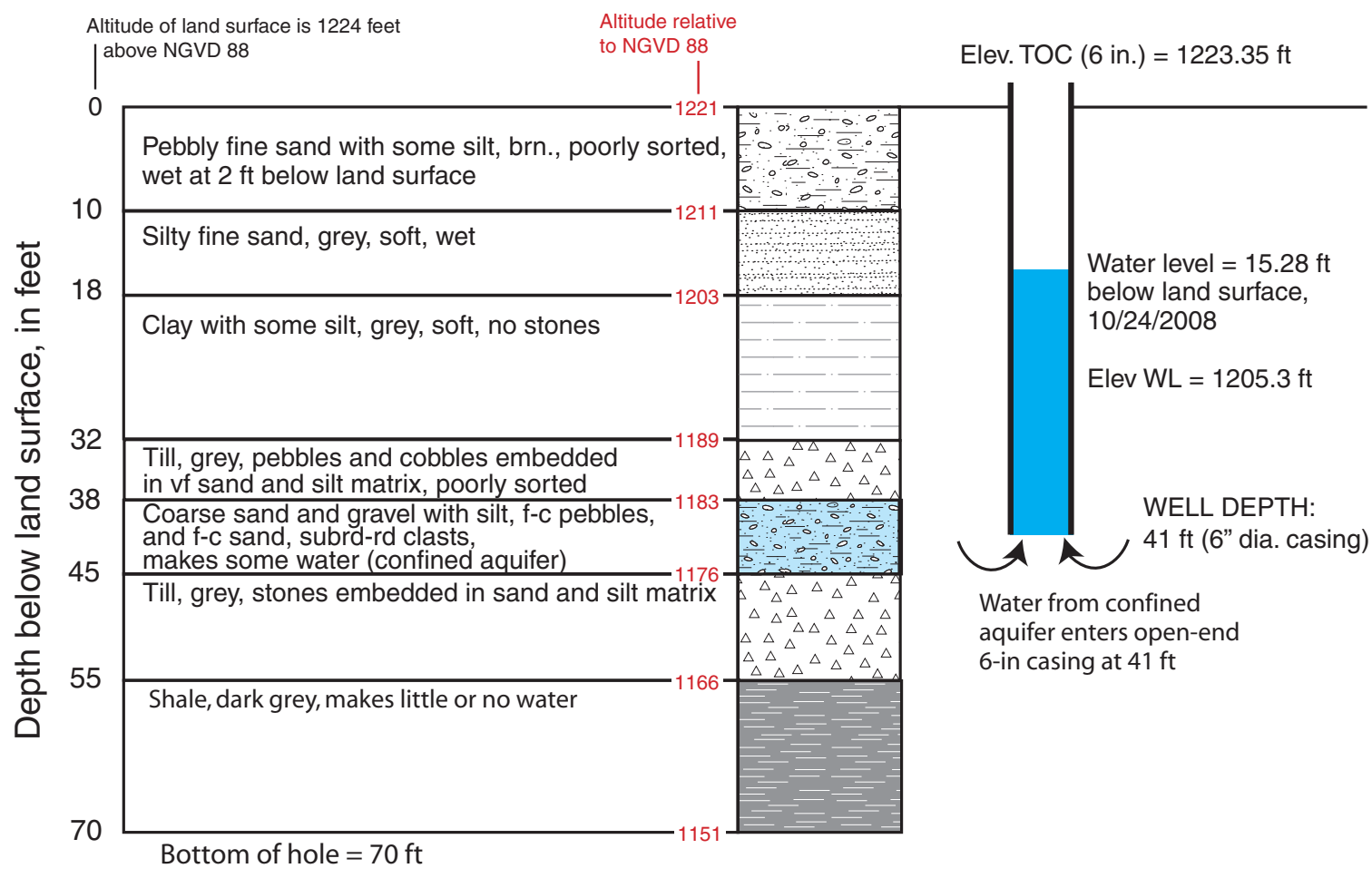

Pulled casing back from $46 \mathrm{ft}$ (no water) to $41 \mathrm{ft}$ and developed well for $1 \mathrm{hr}$ at rate of 3-4 $\mathrm{gal} / \mathrm{min}$.

Figure 2-1. Well log and well construction details of U.S. Geological Survey test well TM2588 near the Hamlet of Danby, Town of Danby, Tompkins County, New York. 


\section{USGS TEST WELL TM2467}

Danby Highway Department, 93 Hornbrook Rd., Danby, N.Y.

Site ID: 422119076282401

Site name: TM2467 (75 ft deep well)

Latitude: $42^{\circ} 21^{\prime} 19.16^{\prime \prime}$

Longitude: $076^{\circ} 28^{\prime} 23.71^{\prime \prime}$
Date completed: 11/14/2007

Drilling contractor: Barber \& DeLine, Tully, NY

6 inch diameter steel casing

Casing above ground $=1.4 \mathrm{ft}$

Latitude and longitude measurement made by GPS unit (NAD83)

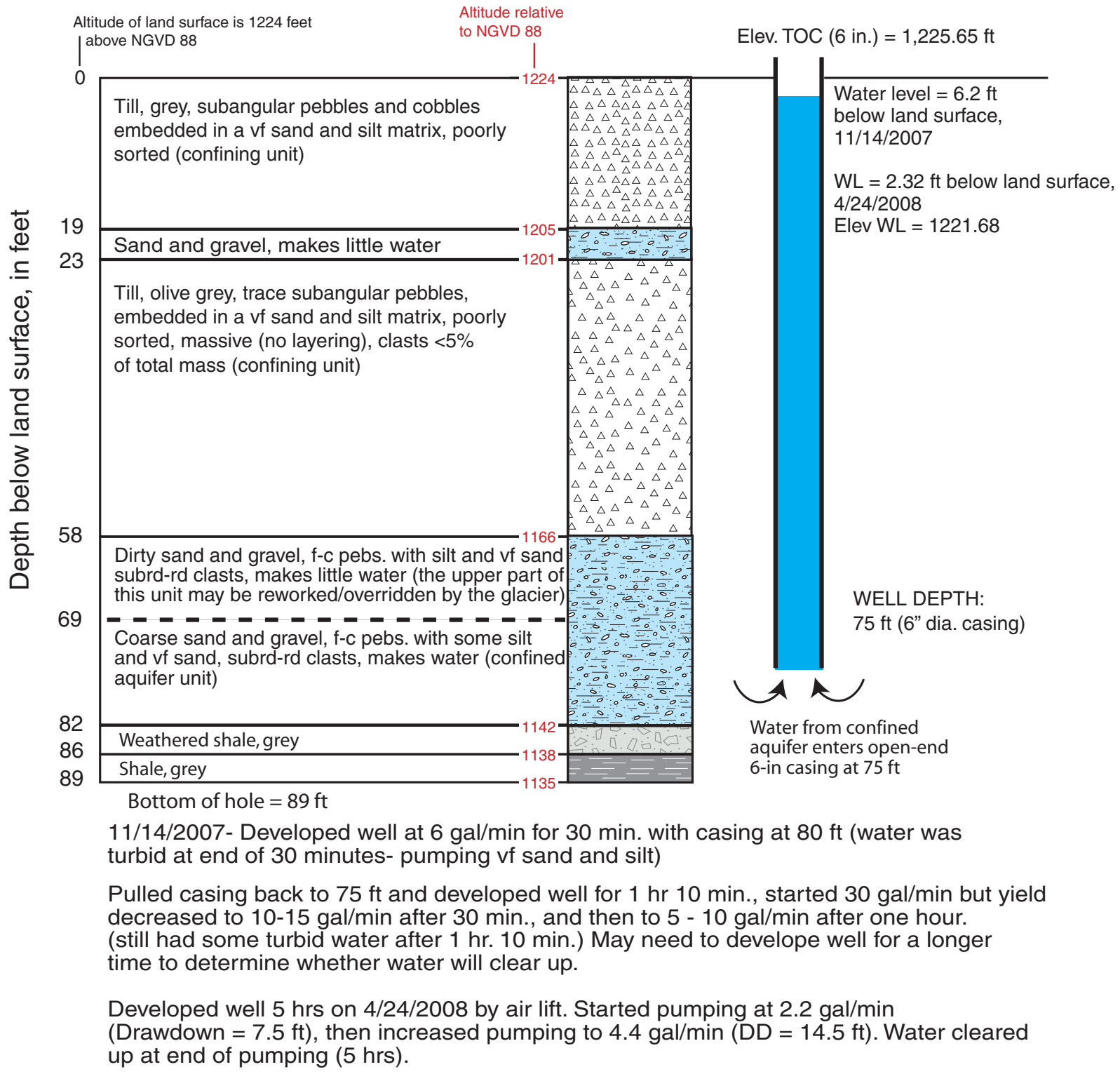

Collected water quality sample (common ions, trace metals, nutrients)

Figure 2-2. Well log and well construction details of U.S. Geological Survey test well TM2467 at the Danby Highway Department near Hornbrook Road, Town of Danby, Tompkins County, New York. 


\section{USGS TEST WELLS TM2590 and TM1035}

Durfee Hill Road, Town of Danby, N.Y.

Site name: TM2590 (well depth $=27 \mathrm{ft}$ )

Site ID: 421934076251001

Latitude: $42^{\circ} 19^{\prime} 34.01^{\prime \prime}$

Longitude: $076^{\circ} 25^{\prime} 10.21^{\prime \prime}$

Date completed: $10 / 28 / 2008$

6 inch diameter steel casing

Casing above ground $=3.0 \mathrm{ft}$
Site name: TM1035 (well depth $=88 \mathrm{ft}$ )

Site ID: 421934076251002

Latitude: $42^{\circ} 19^{\prime} 34.06^{\prime \prime}$

Longitude: $076^{\circ} 25^{\prime} 10.14^{\prime \prime}$

Date completed: 10/28/2008

6 inch diameter steel casing

Casing above ground $=2.7 \mathrm{ft}$

Latitude and longitude measurement made by GPS (NAD83)

Drilling contractor: Barber \& DeLine, Tully, NY

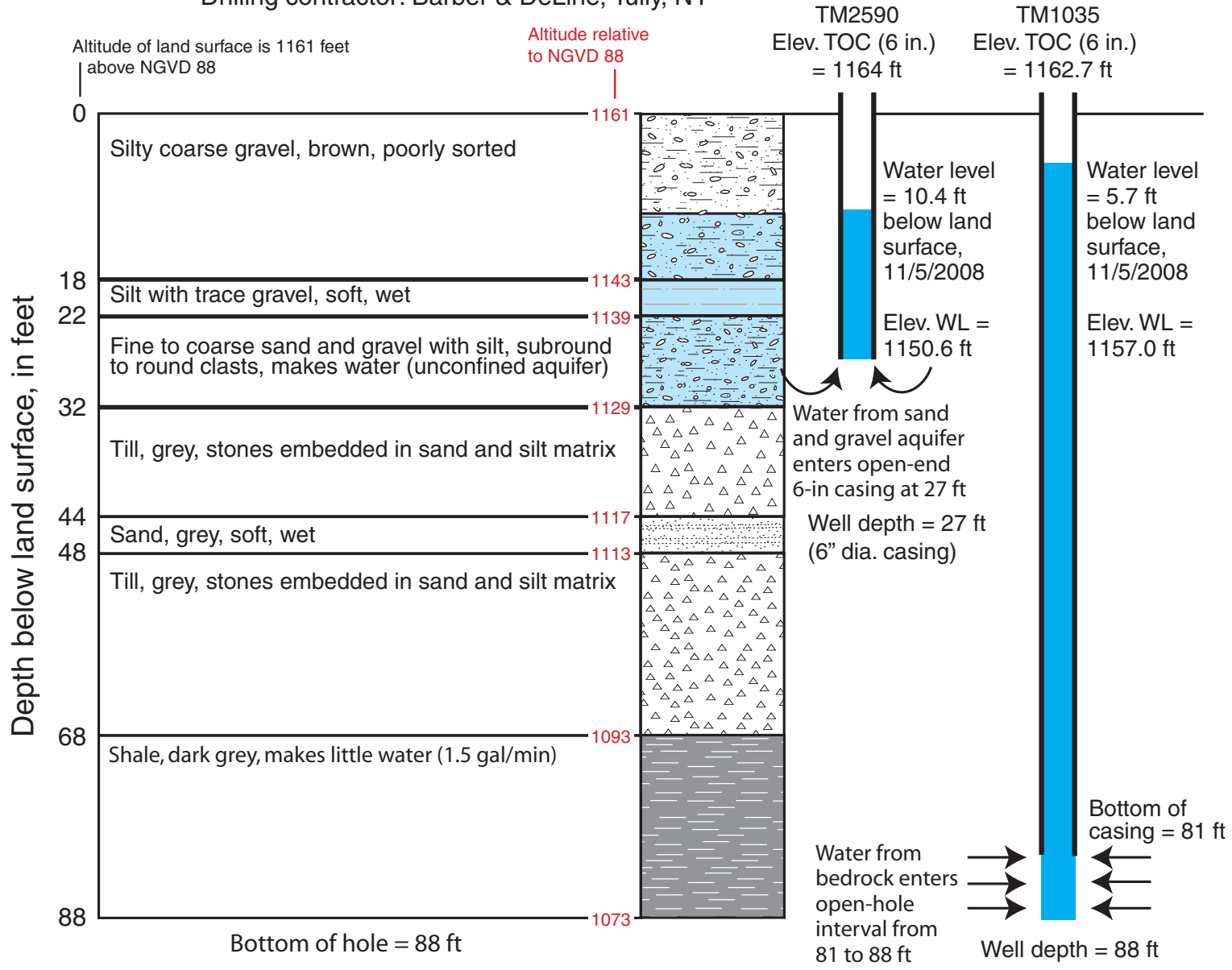

Developed well TM2590 for $1 \mathrm{hr}$ at rate of $20 \mathrm{gal} / \mathrm{min}$.

Developed well TM1035 for $0.5 \mathrm{hr}$ at rate of $1.5 \mathrm{gal} / \mathrm{min}$.

Figure 2-3. Well logs and well construction details of U.S. Geological Survey test wells TM2590 and TM1035, Durfee Hill Road, Town of Danby, Tompkins County, New York. 


\section{USGS TEST WELLS TM2589 and TM2591}

\section{Steam Mill Road, Town of Danby, N.Y.}

Site name: TM2591 (well depth $=27 \mathrm{ft}$ )

Site ID: 422052076273101

Latitude: $42^{\circ} 20^{\prime} 51.60^{\prime \prime}$

Longitude: $076^{\circ} 27^{\prime} 31.09^{\prime \prime}$

Date completed: 10/24/2008

6 inch diameter steel casing

Casing above ground $=3.2 \mathrm{ft}$
Site name: TM2589 (well depth $=100 \mathrm{ft}$ )

Site ID: 422052076273102

Latitude: $42^{\circ} 20^{\prime} 51.57^{\prime \prime}$

Longitude: $076^{\circ} 27^{\prime} 30.97^{\prime \prime}$

Date completed: 10/24/2008

6 inch diameter steel casing

Casing above ground $=2.9 \mathrm{ft}$

Latitude and longitude measurement made by GPS (NAD83)

Drilling contractor: Barber \& DeLine, Tully, NY

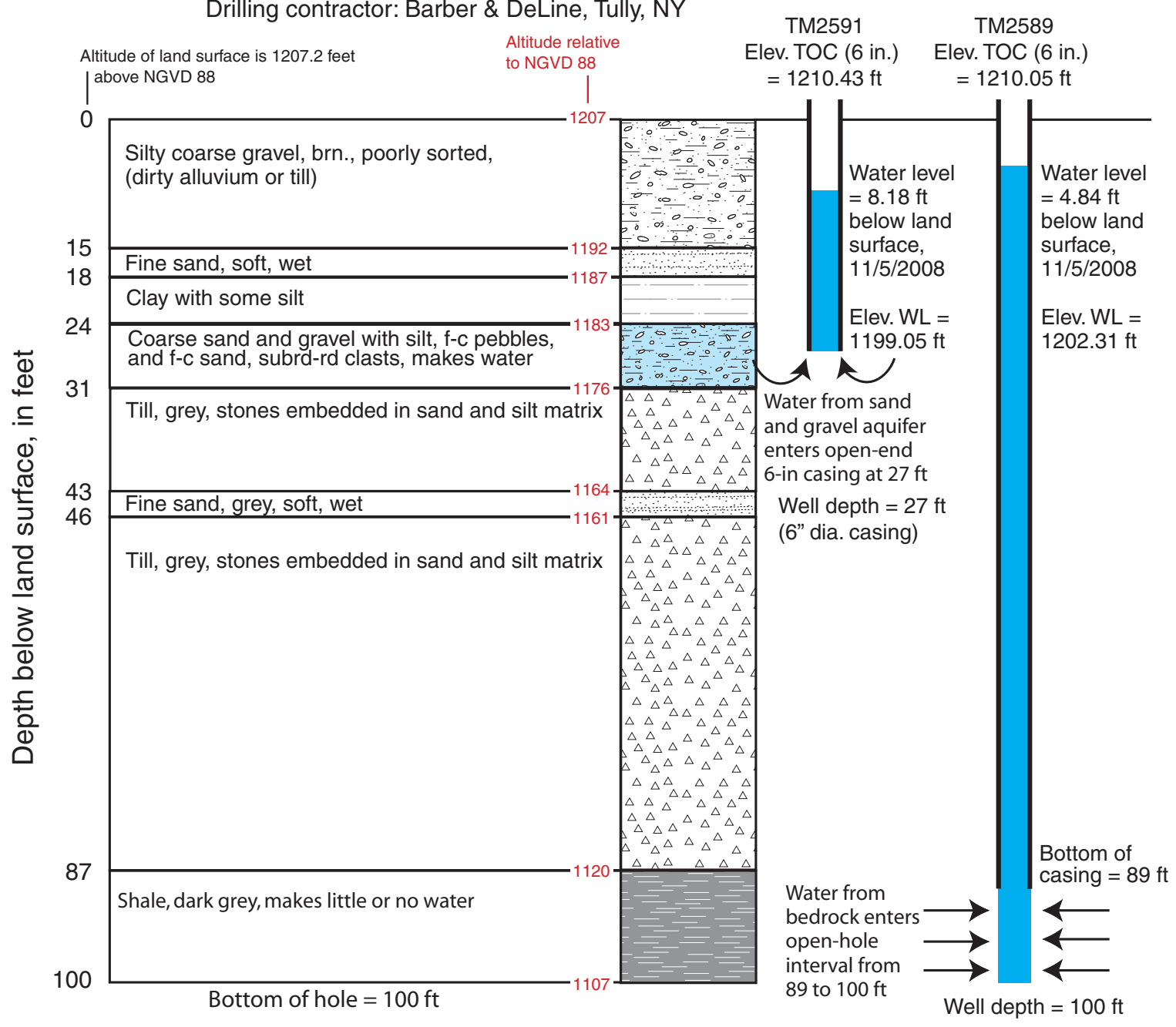

Developed well TM2591 for $1 \mathrm{hr}$ at rate of $20 \mathrm{gal} / \mathrm{min}$.

Developed well TM2589 for $0.5 \mathrm{hr}$ at rate of $0.1 \mathrm{gal} / \mathrm{min}$.

Figure 2-4. Well log and well construction details of U.S. Geological Survey test wells TM2589 and TM2591, Steam Mill Road, Town of Danby, Tompkins County, New York. 


\section{USGS TEST WELL TM2806}

Whitehawk Lane, Town of Danby, N.Y.

Site name: TM2806 (well depth $=47 \mathrm{ft})$

Site ID: 422116076284701

Latitude: $42^{\circ} 21^{\prime} 43.36^{\prime \prime}$

Longitude: $076^{\circ} 29^{\prime} 11.11^{\prime \prime}$
Date completed: 10/14/2010

Drilling contractor: Barber \& DeLine, Tully, NY

6 inch diameter steel casing

Casing above ground $=3.0 \mathrm{ft}$

Latitude and longitude measurement made by GPS (NAD83)

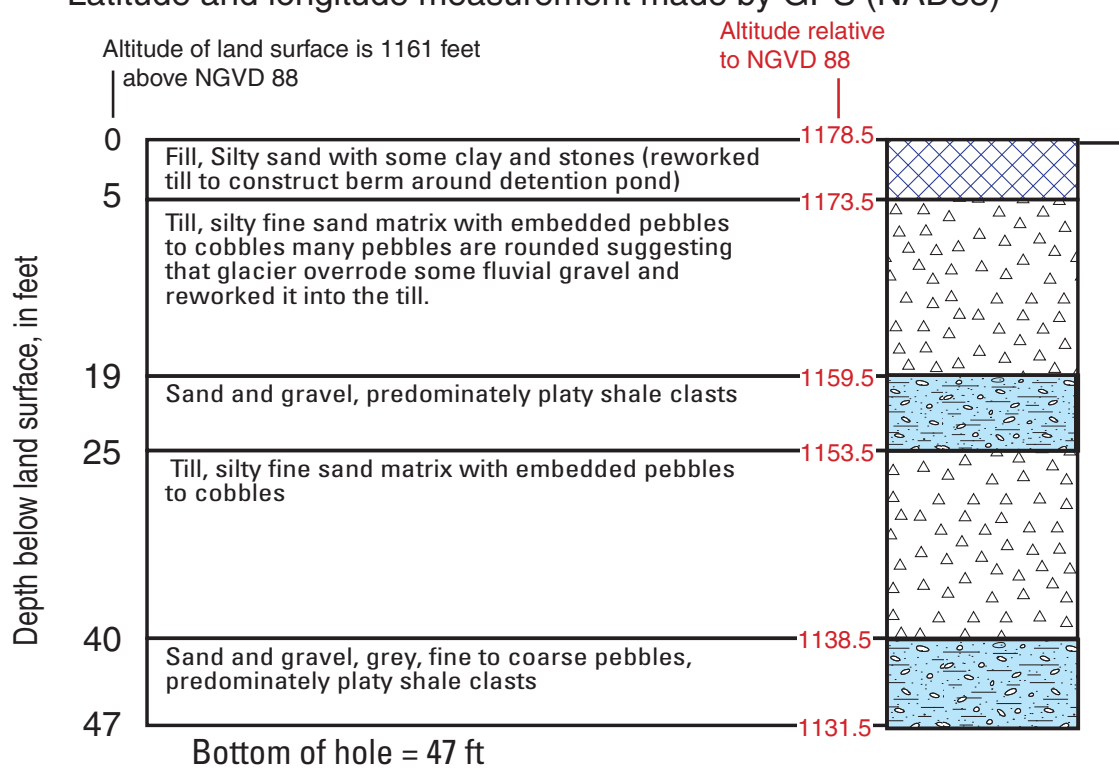

A passive seismic survey conducted at this site indicated that bedrock was at depth $=53 \mathrm{ft}$
Elev. TOC $(6$ in. $)=1181.5 \mathrm{ft}$

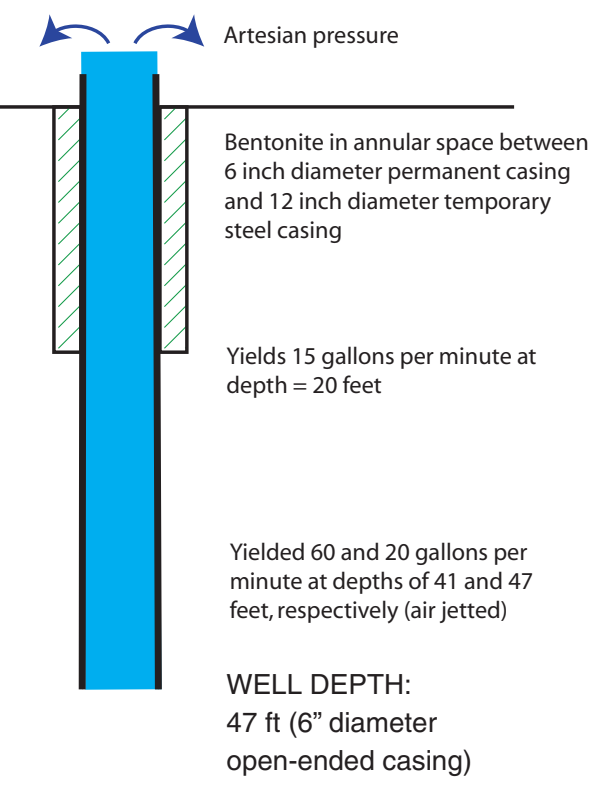

Figure 2-5. Well log and well construction details of U.S. Geological Survey test well TM2806, Whitehawk Lane, Town of Danby, Tompkins County, New York. 
For more information concerning this report, contact: Director, New York Water Science Center

U.S. Geological Survey

30 Brown Road

Ithaca, NY 14850

Information requests:

(518) 285-5602

or visit our Web site at:

http://ny.water.usgs.gov

Publishing support by:

the Pembroke and Rolla Publishing Service Centers 
